December 1989

OPERATION, MAINTENANCE AND EVALUATION OF THE BONIFER AND MINTHORN SPRINGS JUVENILE RELEASE AND ADULT COLLECTION FACILITIES

Annual Report 1988

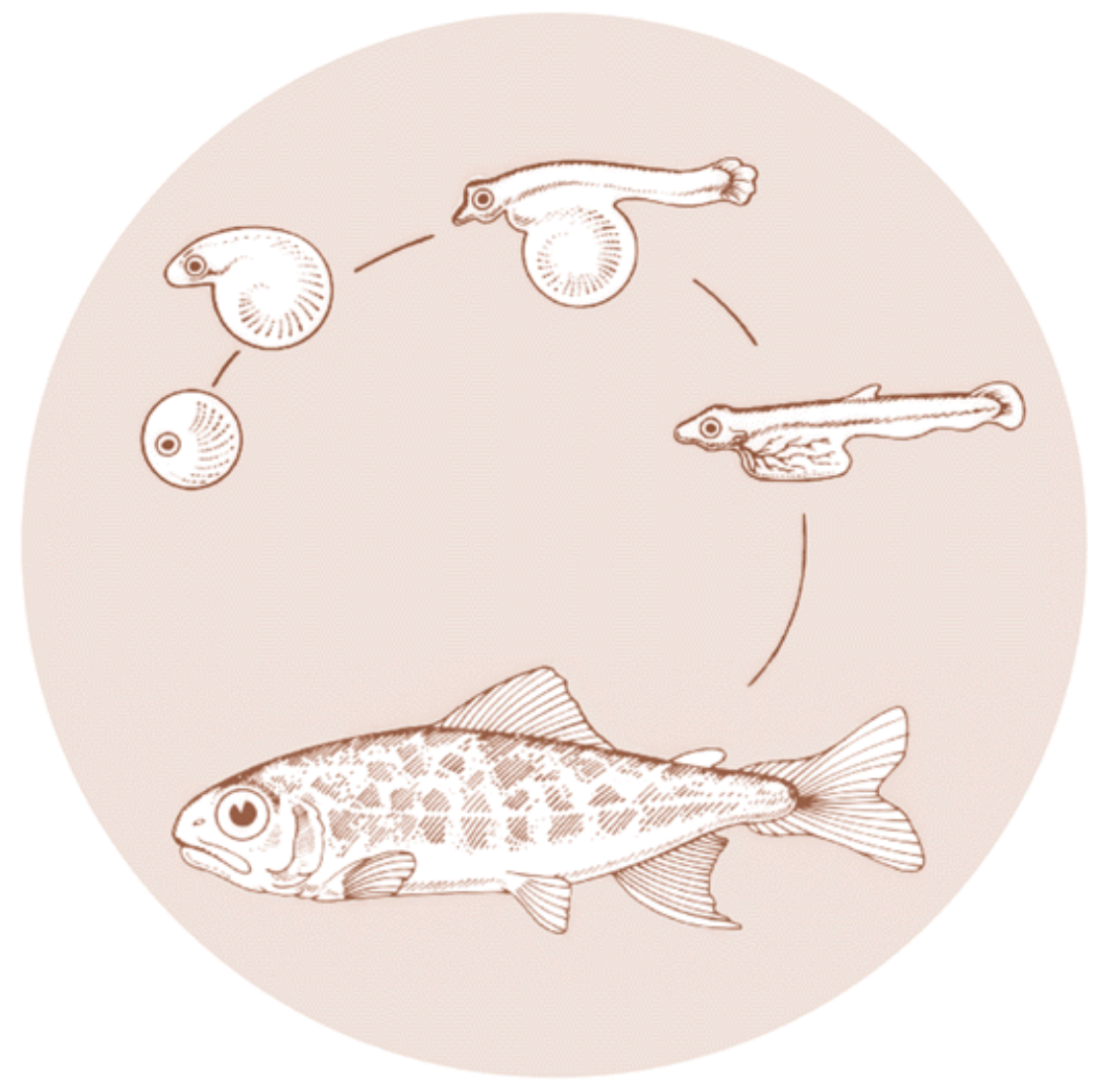

DOE/BP-17622-3 
This report was funded by the Bonneville Power Administration (BPA), U.S. Department of Energy, as part of BPA's program to protect, mitigate, and enhance fish and wildlife affected by the development and operation of hydroelectric facilities on the Columbia River and its tributaries. The views of this report are the author's and do not necessarily represent the views of BPA.

This document should be cited as follows:

Lofy, Peter T., Confederated Tribes of the Umatilla Indian Reservation, Operation, Maintenance and Evaluation of the Bonifer and Minthorn Springs Juvenile Release and Adult Collection Facilities, Annual Report 1988 to Bonneville

Power Administration, Portland, OR, Contract 84-AI-17622, Project 83-435, 81 electronic pages (BPA Report DOE/BP-17622-3)

This report and other BPA Fish and Wildlife Publications are available on the Internet at:

\section{http://www.efw.bpa.gov/cgi-bin/efw/FW/publications.cgi}

For other information on electronic documents or other printed media, contact or write to:

Bonneville Power Administration

Environment, Fish and Wildlife Division

P.O. Box 3621

905 N.E. 11th Avenue

Portland, OR 97208-3621

Please include title, author, and DOE/BP number in the request. 


\title{
OPERATION, MAINTENANCE AND EVALUATION OF THE BONIFER AND MINTHORN SPRINGS JUVENILE RELEASE AND ADULT COLLECTION FACILITIES
}

\author{
Annual Report 1988
}

\author{
Prepared by: \\ Peter T. Lofy \\ Confederated Tribes of the Umatilla Indian Reservation
}

\author{
Prepared for: \\ U.S. Department of Energy \\ Bonneville Power Administration \\ Environment, Fish and Wildlife \\ PO Box 3621 \\ Portland, Oregon 97208 \\ Project No. 83-435-00 \\ Contract No. DE-AI79-84BP17622
}

December 1989 


\section{ABSTRACT}

The Confederated Tribes of the Umatilla Indian Reservation and Oregon Department of Fish and Wildlife are cooperating in a joint effort to increase steelhead and re-establish salmon runs in the Umatilla River Basin. As part of this program, Bonifer and Minthorn Acclimation Facilities are operated for holding adult steelhead and acclimation and release of juvenile salmon and steelhead.

Regularly-scheduled maintenance was completed in 1988 . Equipment and pumps received regular maintenance and repair. The alarm system was upgraded to activate the alarm faster than with the previous configuration. A survey was completed by an hydrologist to determine the change of the Umatilla River contour in the vicinity of Minthorn after the flood in the spring of 1986 , and provide recommendations. A report will be submitted in 1989.

A total of 133 adult steelhead were collected at Threemile Dam January through March and held at Minthorn. Thirty-one pairs were spawned (22 pairs from Minthorn and 9 pairs collected and immediately spawned at Threemile Dam). The 176,533 eggs were transferred to Irrigon Hatchery for incubation and later moved to Oak Springs Hatchery for rearing.

Two marked adult steelhead returned to Bonifer in 1988 . However, 250 hatchery steelhead released from Bonifer (about 10\% of total Umatilla River run) returned to the Threemile Dam trap in the lower Umatilla River in Fall 1987 through Spring 1988.

Acclimation and release of 101,000 fall and 106,000 spring chinook salmon were completed at Bonifer. At Minthorn, 101, 000 fall chinook and 30,000 summer steelhead were acclimated and released. These releases occurred in spring of 1988 without any major losses of fish. Substantial losses of fall chinook salmon at Minthorn and spring chinook salmon at Bonifer took place during fall acclimation due to outbreaks of Ichthioohthirius.

The progress of outmigration for acclimated releases was monitored at the juvenile salmonid trap located at Westland Diversion. Because the fish in each release were not uniquely identified, fish size and migration timing were used to discern general trends. Data suggested that juvenile salmonids started showing up at the trap within about 3 days after release until June 20, when sampling was discontinued. Daily trapping rate was highest in May.

Collection of data to assess the holding and rearing capacities of the two acclimation facilities was initiated. Temperatures and dissolved oxygen were recorded. Contact was made with the ODFW Eastern Oregon Fish Pathology Laboratory to take disease samples of Umatilla River summer steelhead broodstock for monitoring purposes, to certify eggs, and to examine Bonifer and Minthorn fish when the epizootic of Ich occurred. Fish Management 
Consultants Inc. was hired to determine the most efficient way to use the Bonifer Facility. As part of their report, a survey to estimate volume and area of Bonifer Pond was completed. A draft report of recommendations was submitted.

Test and control groups (each group with three replicates) were coded-wire tagged by ODFW under subcontract. Fish were tagged for one experiment for fall chinook salmon, two experiments for spring chinook salmon (spring and fall releases) and one experiment for summer steelhead. 


\section{ACRNOWLEDGEMENT8}

This study was funded by Bonneville Power Administration. The CTUIR thanks Jerry Bauer and other BPA personnel for their assistance. Thanks are extended to Susan Whelan of the StanfieldWestland Irrigation District, Tom Collom, Jim Phelps, Mike Black, Ray Hill, Mike Gribble, Warren Groeberg, Sam Onjukka and other ODFW personnel for providing assistance in the collection of data and spawning of summer steelhead. We thank the landowners, Rosemary and Wes Gladow, and Richard Kaye for their cooperation and the Union Pacific Railroad for providing access to the acclimation facilities.

Thanks go to CTUIR staff, whose cooperation and contributions are evident in this report. Doug Olson and Bryson Bronson collected much of the adult return data at Threemile Dam and juvenile salmonid migration data at Westland juvenile salmonid trap. Numerous biologists and technicians assisted in field sampling. Julie Burke and Celeste Reves typed numerous drafts of this report and Doug Olson and Gary James provided critical review. Keith Kutchins prepared basic summaries of hourly temperature data.

Special thanks go to Larry Cowapoo for the long hours and weekends running the facilities and collecting much of the data included in this report. 


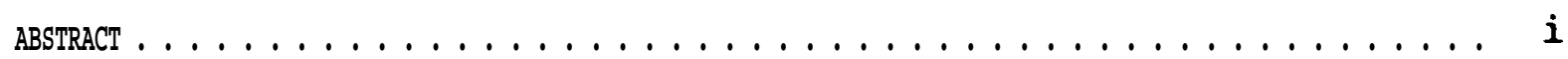

ACKNOWLEDGEMENTS $\ldots \ldots \ldots \ldots \ldots \ldots \ldots \ldots \ldots \ldots \ldots$

TABLE OF CONTENTS $\ldots \ldots \ldots \ldots \ldots \ldots \ldots \ldots$

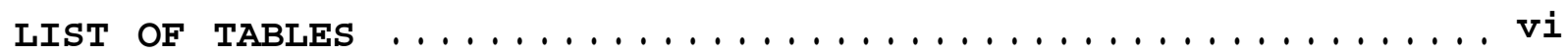

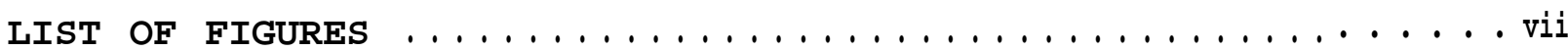

INTRODUCTION

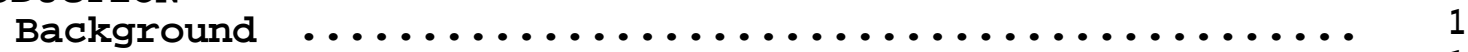

Facility Description \& Operations $\ldots \ldots \ldots \ldots \ldots \ldots \ldots \ldots$

Project objectives ...................... 4

MATERIALS AND METHODS

Collection Spawning of Summer steelhead ......... 6

Disease Sampling of Summer Steelhead ............. 6

Adult Returns to Bonifer .................... 7

Acclimation and Release of Juvenile Salmonids ....... 7

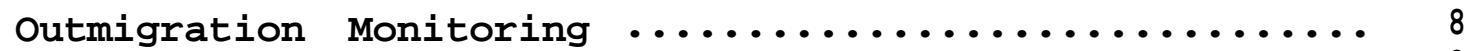

Assessment of Acclimation Facilities $\ldots \ldots \ldots \ldots \ldots \ldots$

Acclimation $\operatorname{Research} \ldots \ldots \ldots \ldots \ldots \ldots \ldots \ldots \ldots \ldots$

RESULTS AND DISCUSSION

Facility Maintenance ...................... 10

Collection and spawning of summer steelhead ........... 10

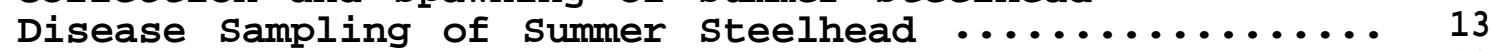

Adult Returns to Bonifer ...................... 13

Acclimation and Release of Juvenile Salmonids ........ 15

Acclimation at Minthorn
Fall chinook salmon $-3 / 8 \ldots \ldots \ldots \ldots \ldots \ldots \ldots$

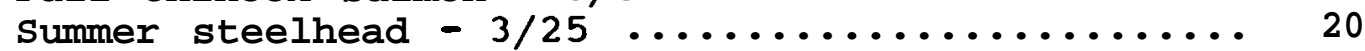

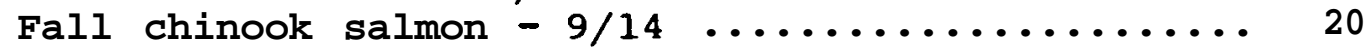

Acclimation at Bonifer

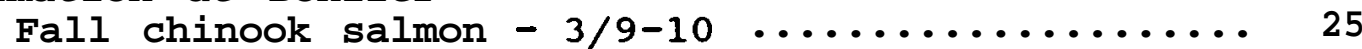

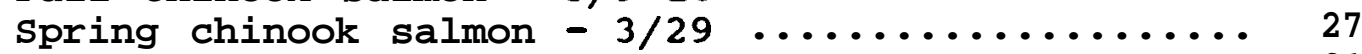

Spring chinook salmon $-9 / 13 \ldots \ldots \ldots \ldots \ldots \ldots \ldots \ldots$

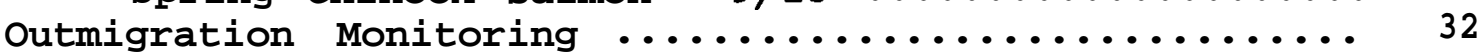

Assessment of Acclimation Facilities ............. 32

Acclimation Research ..................... 34

Project Difficulties

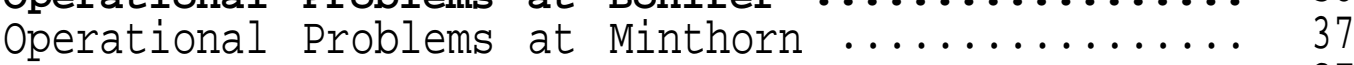

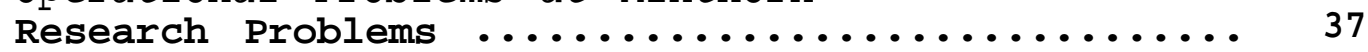

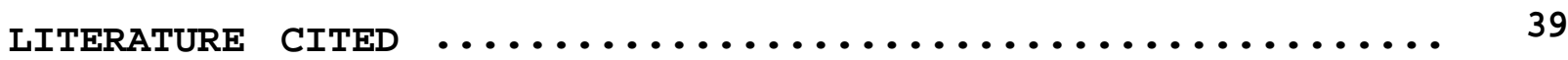

APPENDICES $\ldots \ldots \ldots \ldots \ldots \ldots \ldots \ldots \ldots \ldots \ldots \ldots \ldots \ldots \ldots \ldots$ 


\section{LIST OF TABLE8}

Number

1. Collection and transport of steelhead broodstock 1988

2. Results of disease sampling of spawned and prespawned mortality in 1988 for Umatilla River

broodstock

3. Juvenile salmon and steelhead released in the Umatilla River Basin $-1988 \ldots \ldots \ldots \ldots \ldots \ldots$

4. Liberation information for upriver bright fall chinook salmon coded-wire tagged and released in the Umatilla River Basin in 1988.

5. Juvenile salmonid and steelhead released into the Umatilla River Basin -1980's . . . . . . . . . . . . . . . . . 18

6. Liberation information for all coho salmon coded-wire tagged and released in the Umatilla River Basin ......

7. Liberation information for all summer steelhead codedwire tagged and released in the Umatilla River Basin..

8. Liberation information for all spring chinook salmon coded-wire tagged and released in the Umatilla River 


\section{LIST OF FIGURES}

Number

Page

1. Umatilla River Basin and Confederated Tribes of the Umatilla Indian Reservation . . . . . . . . . . . . . . . . . . . . 2

2. Bonifer and Minthorn Acclimation Facilities and

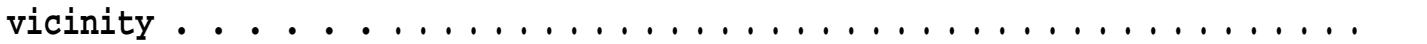

3. Historic versus 1987-88 run of summer steelhead in the

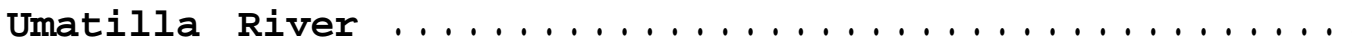

4. Length frequencies of non-experiemntal fall chinook salmon released from Minthorn 3/27-28 - marked

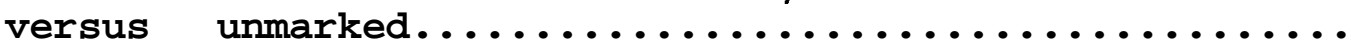

5. Length frequencies of experimental groups summer steelhead released at Minthorn 4/18-19 test

versus control group . . . . . . . . . . . . . . . . .

6. Length frequencies of experimental groups of fall chinook salmon released at Minthorn 11/3-4

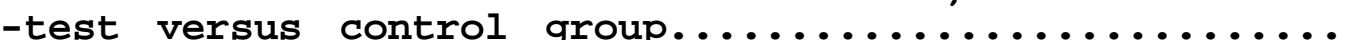

7. Length frequencies of non-experimental fall chinook salmon released from Bonifer 3/24-25 - marked versus unmarked $\ldots \ldots \ldots \ldots \ldots \ldots$

8. Length frequencies of marked experimental spring chinook salmon released at Bonifer and in the lower Umatilla River $3 / 29$ - 4/30 - test versus control

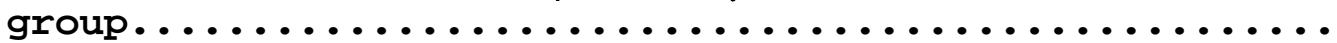

9. Length frequencies of experimental groups of spring chinook salmon released at Bonifer 11/8-10 -

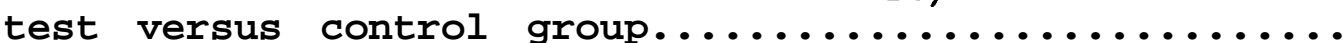




\section{APPENDICES}

Number

Page

A. Steelhead broodstock spawning and mortality at Minthorn Acclimation Facility and Threemile Dam

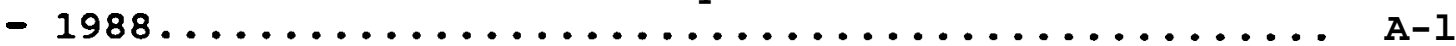

B. Date of spawning for summer steelhead versus date of collection. ............................

C. Summary of descaling data from pre-release sampling

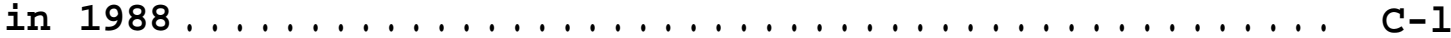

D. Electronic thermograph data taken hourly from Minthorn for $1988 \ldots \ldots \ldots \ldots \ldots \ldots \ldots$ D-1

E. Dissolved oxygen at Minthorn Acclimation Facility 1988

F. Electronic thermograph data taken hourly from

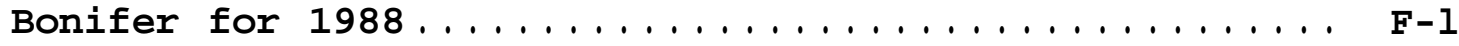

G. Dissolved oxygen and temperature at Bonifer

Acclimation Facility in $1988 \ldots \ldots \ldots \ldots \ldots \ldots$

H. Estimated number and daily rate of juvenile salmonids captured at Westland juvenile salmonid trap in $1988 \ldots$ H-1

I. Coded-wire tagging of juvenile salmonids in 1988 for release into the Umatilla River Basin to evaluate acclimation 


\section{INTRODUCTION}

Background

The Umatilla River system has historically supported large populations of anadromous salmonids, including summer steelhead (Oncorhvnchus mykiss), fall and spring chinook salmon (ㅇ. tshawvtsha) and coho salmon (‥ kisutch). The only native anadromous stock left in the basin is a small run of approximately 2,000 summer steelhead. This steelhead run was supplemented 1967 through 1970 with Skamania and Idaho (Oxbow) stocks and Umatilla River stock in 1975 and 1981 to the present (CTUIR 1988). The run was $10 \%$ hatchery (adipose fin-clipped) fish in 1987-88 (the first season that fin-clipped fish were differentiated). Large runs of chinook and coho salmon were essentially eliminated in the early 1900's. Irrigation, agriculture, logging and hydropower are among the developments that have impacted all of these stocks in the Umatilla River Basin.

A comprehensive plan developed by the Confederated Tribes of the Umatilla Indian Reservation (CTUIR) and the Oregon Department of Fish and Wildlife (ODFW) was implemented to bolster steelhead and re-establish salmon runs in the Umatilla River Basin. Among the initial steps toward rebuilding the runs was construction of two acclimation facilities completed on the Umatilla Indian Reservation under the Fish and Wildlife Program of the Northwest Power Planning Council, and funded by Bonneville Power Administration (BPA).

\section{Facility Descriptions and Operations}

The Bonifer Pond Facility (Bonifer) is located on the upper Umatilla River drainage at Meacham Creek river-mile (RM) 2.0 . Meacham Creek empties into the Umatilla River at RM 79 (Figures 1 \& 2). The pond empties into Boston Canyon Creek which flows about 50 yards before its confluence with Meacham Creek. Construction of water control structures completed at the outlet of an existing pond was completed in the fall of 1983 and operations began in early 1984. The 1.75-acre pond has 4.5 acre-feet of water (Fish Management Consultants Inc. 1988). The pond is fed by three springs that originate from $1 / 8$ to $1 / 2$ mile away, the largest of which parallels the railroad in a series of large pools before emptying into Bonifer. A concrete fishway that is used as an adult holding area, and a juvenile release culvert that runs parallel to the fishway, are the two release structures at the outlet of the pond.

The Minthorn Springs Facility (Minthorn) is located about four miles east of Mission, Oregon (Figures $1 \& 2$ ). Minthorn Springs Creek is formed from the confluence of several springs located immediately south of the Umatilla River. The creek is about one mile long, with the facility located near the mouth at Umatilla RM 


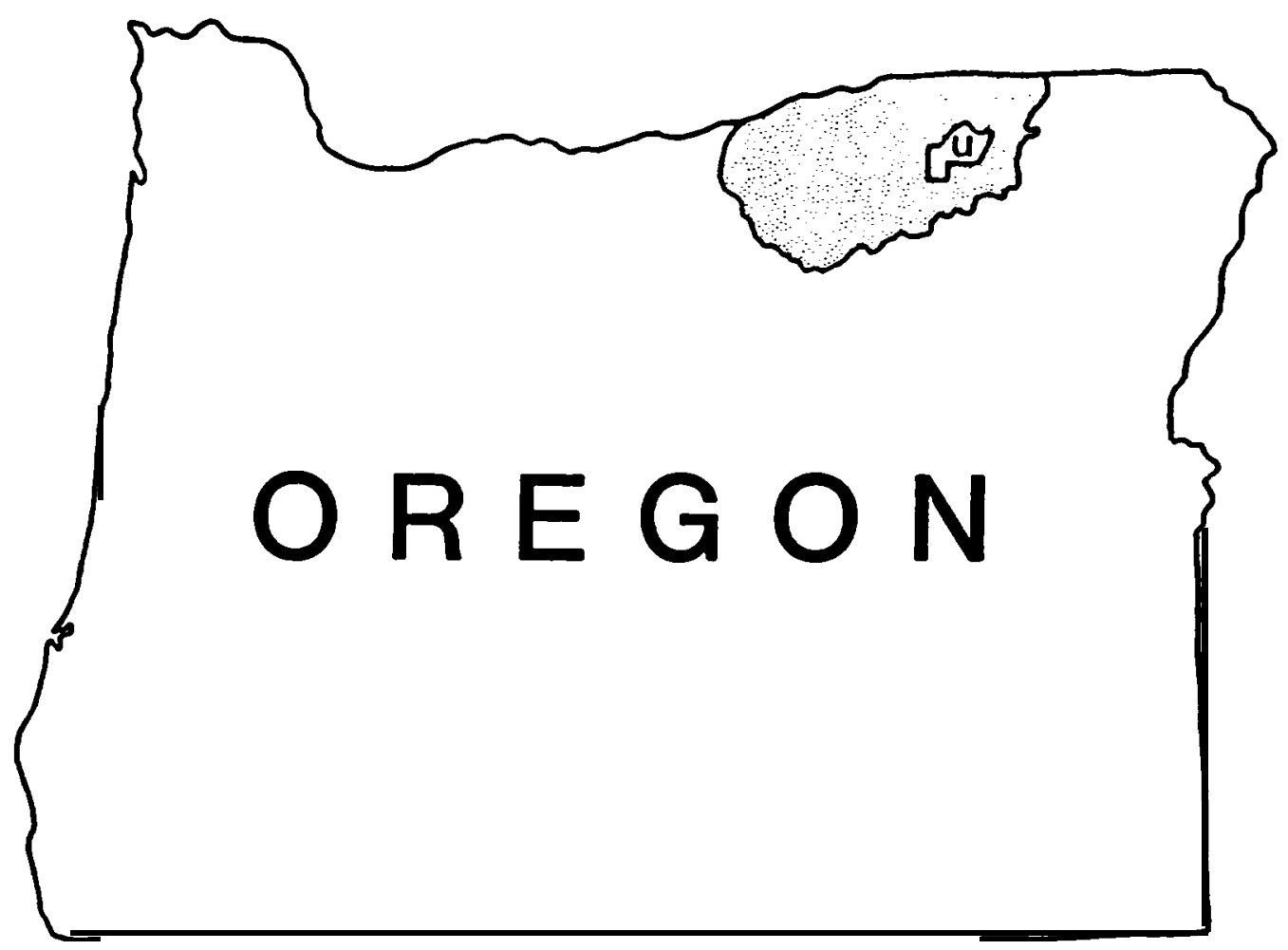

Figure 1. Umatilla River Basin and Confederated Tribes of the Umatilla Indian Reservation (u). 


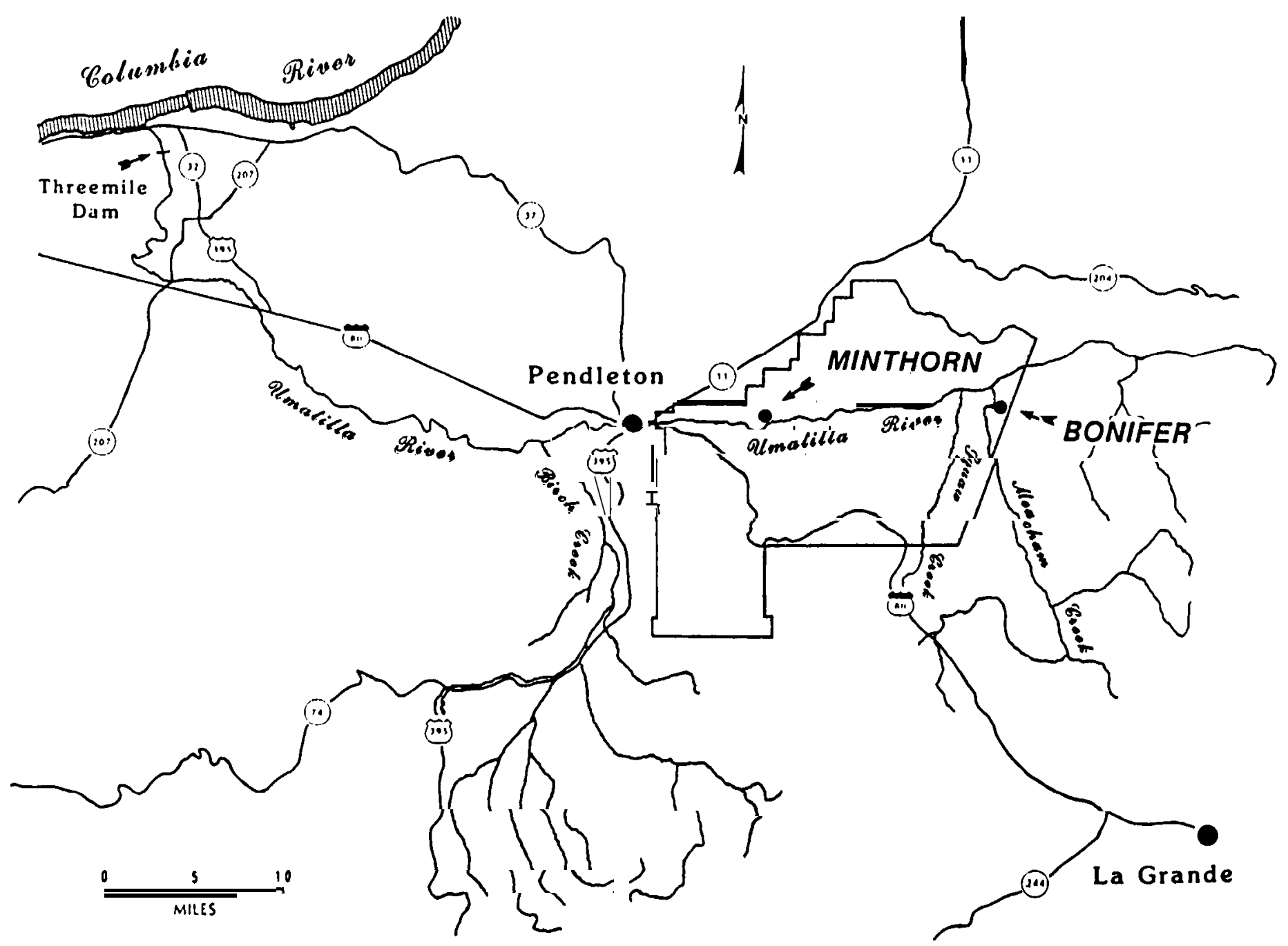

Figure 2. Bonifer and Minthorn Acclimation Facilities and vicinity. 
63. The facility was completed in December of 1985 and first used for juvenile acclimation in the spring of 1986. Two concrete raceways (120 x 12 feet) were constructed for acclimation and holding of juvenile salmonids. Water is pumped about 40 feet from Minthorn Springs Creek to the raceways. Water depth is usually held at 3 feet with a single-pass water pumping rate of 800 gallons per minute (gpm) through each raceway. The facility has the capability to release raceway outflows upstream or downstream of the pump intake. This feature allows for either recycling of flows (if desired) and release of juveniles downstream of the pump intake.

The Bonifer and Minthorn Acclimation Facilities (BMAF) are operated by CTUIR with cooperation from ODFW. The facilities have been used for holding and spawning of adult summer steelhead and for acclimation and release of juvenile fall and spring chinook and coho salmon and summer steelhead. The main goals of acclimation are to reduce stress from trucking prior to release and improve imprinting of juvenile salmonids to increase adult return to the Umatilla River. In addition, it is desired to produce an acclimation environment that is favorable for smoltification. The proposed Umatilla Hatchery will eventually be the source hatchery for Bonifer and Minthorn and the proposed Umatilla Satellite Facility which may also be used to acclimate juvenile salmonids. Until that time, fish are being acquired from various sources. This report details activities associated with operation, maintenance and evaluation of the Bonifer and Minthorn facilities in 1988 .

\section{Project Objectives}

The following specific project objectives for 1988 are part of overall objectives to operate, maintain and evaluate Bonifer and Minthorn Acclimation Facilities:

1. Collect and transport adult steelhead from the lower Umatilla River to facilities.

2. Hold and artificially spawn adult steelhead and transport eggs.

3. Acclimate and release groups of juvenile salmon and steelhead.

4. Monitor general condition and health of adults and juveniles.

5. Maintain, repair and service equipment, building and grounds.

6. Place tags in experimental groups of juvenile spring and fall chinook salmon and summer steelhead for acclimation studies.

7. Cooperate in data collection at juvenile salmonid traps to determine salmonid species composition and number.

8. Compare length frequency and descaling index of juveniles during pre-release. 
9. Obtain temperature and dissolved oxygen data for both acclimation facilities.

10. Collect snouts and information from coded-wire tagged adult salmonids returning to the Umatilla River and gather information for harvest from the Columbia River and ocean. 


\section{MATERIAL8 AND METHODS}

\section{Collection and spawning of Summer Steelhead}

Adult steelhead were collected for broodstock through the cooperative efforts of CTUIR, ODFW and Stanfield-Westland Irrigation District. Fish were trapped at Threemile Dam, located three miles upstream from the mouth of the Umatilla River. The dam has ladders on both the east and west sides. Both ladders are being renovated under BPA funding as a part of the Umatilla Fisheries Restoration Program.The trapping facility on the east side was operated from October 20, 1987 through June 17, 1988.

Adult steelhead were differentially marked each collection day and transported to acclimation facilities using a trailer with a 400-gallon, aerated tank. Fish were checked for condition weekly and sexual maturation monthly until late March. When the first fish began to ripen, they were checked for maturation weekly. Ripe fish were spawned by Irrigon Hatchery and CTUIR personnel using standard hatchery practices. All fish were sorted for sex and ripeness on the first day of spawning. Thereafter, all females were checked weekly for ripeness, and males were handled as necessary to provide pairing for ripe females. Each female was spawned with only one male. Eggs from each pair (family group) were water hardened, placed in buckets, and transported to Irrigon Hatchery to be incubated separately. Eggs from family groups were combined when they were certified as being free from replicating viruses. Eyed eggs were later transferred to Oak Springs Hatchery for rearing. Incubation and rearing of steelhead eggs from adults spawned at acclimation facilities will eventually occur at Umatilla Hatchery, scheduled for completion in 1991.

\section{Disease Sampling of Summer Steelhead - Umatilla River 1988 brood}

Spawned adult steelhead were sampled for presence of selected pathogens by ODFW Northeast Oregon Fish Pathology Laboratory (NOFPL) to certify eggs for transfer from Irrigon Hatchery to Oak Spring for rearing. Additional sampling as part of BPA's Fish Health Monitoring Program was also performed on spawned fish and 20 prespawn mortalities. Sixty-two spawned fish were sampled(31 males and 31 females) for replicating viral agents. Ovarian fluid from females or milt from males and pyloric caeca, kidney and spleen were sampled for infectious hematopoietic necrosis virus (IHNV) and infectious pancreatic necrosis virus (IPNV). Kidney smears from 38 spawned adults were sampled for bacterial kidney disease (BKD) and 16 blood samples were taken to test for erythrocytic inclusion body syndrome (EIBS). Samples of head cartilage were taken to test for Mvxosoma cerebralis (whirling disease) from 44 fish and were assayed as pooled sample of two fish each. 
Nineteen steelhead that died during holding and one fish collected at Threemile Dam were also sampled. Kidney smears were taken for BKD and samples of the lower intestine were examined for Ceratomvxa shasta. Cultures from the kidney were also taken to test for typical bacterial pathogens.

All tests were performed at NOFPL by Warren Groeberg or Sam Onjukka except tests for whirling disease that were performed at the ODFW Fish Pathology Laboratory at Corvallis by Harriet Lorz. IHNV/IPNV tests were performed on family groups to screen the egg take while all other tests were performed on individuals or pooled samples of individuals to determine incidence of the pathogen in the stock.

\section{Adult returns to Bonifer}

The adult trap was operated at Bonifer from the beginning of January through the end of May to collect fish expected to return there.

\section{Acclimation and Release of Juvenile salmonids}

Juvenile salmonids were transported by ODFW from hatcheries using 2,000 to 5,000 gallon liberation units. Transfers were completed in one to four days. Juveniles were fed $3 \mathrm{~mm}$ Biomoist Feed twice a day, in the morning and the afternoon.

Mortalities were removed daily at both facilities. When a specific disease problem was apparent in mortalities or live fish, or unexplained mortality was very high, ODFW pathology personnel were consulted

Transfer mortality (immediate and delayed mortality) was defined as all fish that die within 5 days of the last transfer date. Total number of fish at release is estimated using ODFW hatchery records, ODFW transfer and release reports, acclimation mortality records and ODFW tagging records. Number of fish reported as tagged at release is estimated by sub-sampling for coded-wire tag retention just prior to release. Clipped fish are those with an adipose fin clip for salmon and a left pelvic fin clip plus an adipose fin clip for steelhead. Fish reported as tagged have the correct fin clips and a coded-wire tag.

Samples for length frequency data were taken using standard ODFW techniques. The descaling index was completed in general accordance with criteria used to index descaling at Snake River Dam (Scully et al. 1984). Ten potential descaled areas were identified (five sections on each side of the fish). These scaled sections are above a line extending from the vent to the insertion of the pectoral fin. Descaled fish is defined as one with a loss of greater than $40 \%$ of the scales in at least 2 of these ten sections. Partial descaling addresses smaller loss in scaled areas. We defined partial descaling as greater than $3 \%$ of the scales on at least one side of the fish. 
Temperatures reported associated with specific acclimation periods are data from hourly readings that correspond to the date of first transfer to the last date of release unless otherwise indicated. Incomplete temperature data are available for portions of some acclimation periods. All available data are reported.

Percent body weight of food fed was determined with poundage transferred (ODFW Transfer Reports) and pre-release sampling data (number per pound and estimated number of fish at release).

\section{outmigration Monitoring}

Juvenile salmonids were collected in the trapping facility (smolt trap) at Westland Diversion (RM 27), about 54 and 36 rivermiles downstream from Bonifer and Minthorn, respectively. This was the only place that the outmigration of juvenile salmonids was monitored downstream from the release sites in 1988. The trap was set on $3 / 25$ and operated until $6 / 29$.

Fish length, species and mark were recorded on an enumerated subsample of fish. The total number of fish in the trap was estimated by counting the number of fish in a "net" and estimating the number of fish in each net thereafter. The fish in every fifth or sixth net were actually counted to adjust the estimated number of fish in each scoop because a decreasing number of fish were being removed from the trap as they were counted.

The trapping facility is small and causes fish to be stressed when rowded. A new smolt trap facility is scheduled to be built as a part of the new Westland screens in 1990 .

Assessment of Acclimation Facilities

As part of the Northwest Power Planning Council's Fish and Wildlife Program, the Umatilla Hatchery will provide increased juvenile salmonid production for the Umatilla River Basin. Species-specific carrying capacities at the BMAF for both juveniles and adults at various times of the year are to be calculated based on water quality and quantity. Progress toward collecting the necessary data was initiated in 1987 and continued in 1988.

Automatic temperature recorders (Ryan Tempmentors) were installed at both facilities in late 1987. One was installed at Bonifer outlet and the other at the pump intake at Minthorn. Temperatures were recorded hourly. Operational data, which included dissolved oxygen and other temperatures, were recorded starting in March in the Minthorn raceways and at Bonifer at the outlet and spring inlets. Operational data were generally recorded daily when juveniles were being held. During non-acclimation periods, data were recorded weekly. Oxygen data from Minthorn were 
collected at the pump intake during non-acclimation periods and in the raceways during acclimation because the latter were the environmental conditions to which the fish were exposed.

A Request for Proposal was distributed for evaluation of Bonifer to increase efficiency and address past problems. From the proposals received, CTUIR and BPA concurred in selecting Fish Management Consultants to complete the evaluation.

\section{Acclimation Research}

The first steps toward setting up a research program to determine the benefits of acclimation were initiated in 1987 and were continued in 1988 .

Juvenile salmonids were tagged and marked by ODFW under subcontract. Information reported is from ODFW Coded Wire Tagging Operation Summaries. Three replicate tag codes were used for each test (acclimated) and control (non-acclimated) group. Chinook salmon were coded-wire tagged (CWT) and given an adipose fin clip. Summer steelhead were CWT and had both the adipose and left pelvic fin clipped.

Adult salmonids marked to indicate the presence of coded- wire tags were collected at Threemile Dam. Snouts were taken and data for each fish were recorded. Snouts were sent to ODFW for tag removal and decoding along with associated data. 


\section{RE8ULT8 NMD DI8CU88IOA}

\section{Facility Maintenance}

Various maintenance activities at Minthorn were completed in 1988. All electrical and pumping equipment was checked, and serviced if necessary, before each acclimation group was delivered. The alarm system was wired to activate the alarm as soon as the main pump shuts off (instead of waiting until the water level drops). In addition, an alarm bypass was installed so that the alarm would not automatically be activated at the tribal police when we chose to draw down the raceways. A horn was installed to alert personnel at the facility should the alarm be activated while they are on site. Gates and screens at the pump intake and the inlet and outlet of the raceways were cleaned daily, or more often as required while fish were being held. During other times the intake and adult holding areas were cleaned as necessary.

An hydrologist was hired to review survey work at Minthorn and complete any additional surveys necessary to evaluate alternatives to address fish passage problems associated with the change in streamcourse of Umatilla River as a result of the flood in February 1986. A report will be submitted in 1989 detailing options and the most viable and cost-effective measures from a hydrologic standpoint.

Routine maintenance work at Bonifer consisted mostly of weed abatement in the work area around the outlet and clearing around and maintenance of the electric fence. The cobble barrier at the inlet of Bonifer Springs Creek was rebuilt before the first group of fish was transferred to the facility. An attempt was made to draw down the facility during the summer to dry out the bottom and discourage aquatic weed growth. Spring sources that empty directly into the pond at pond operating level precluded drying of the bottom and emergent plants appeared to thrive in the semi-moist mud. If anything, growth appeared to be greater in number and density than when the pond was left alone.

\section{Collection and Spawning of Adult Summer Steelhead}

A total of 133 adult steelhead were trapped at Threemile Dam and transported to Minthorn (Table 1). The ability to trap all fish passing the dam allowed us to capture more fish at one time for spawning, therefore transport of fish was not necessary as frequently as in past years. Fish were collected from January through March and held through April. Fish collected in April were spawned at Threemile Dam without transport. Fish were collected later than we had originally planned because the run returned later than normal. About 45\% of the run passes the trap by the end of January in a normal year, but only about 10 percent had passed in the 1987-88 season (Figure 3). 
Table 1. Collection and transport of steelhead broodstock - 1988. 1/

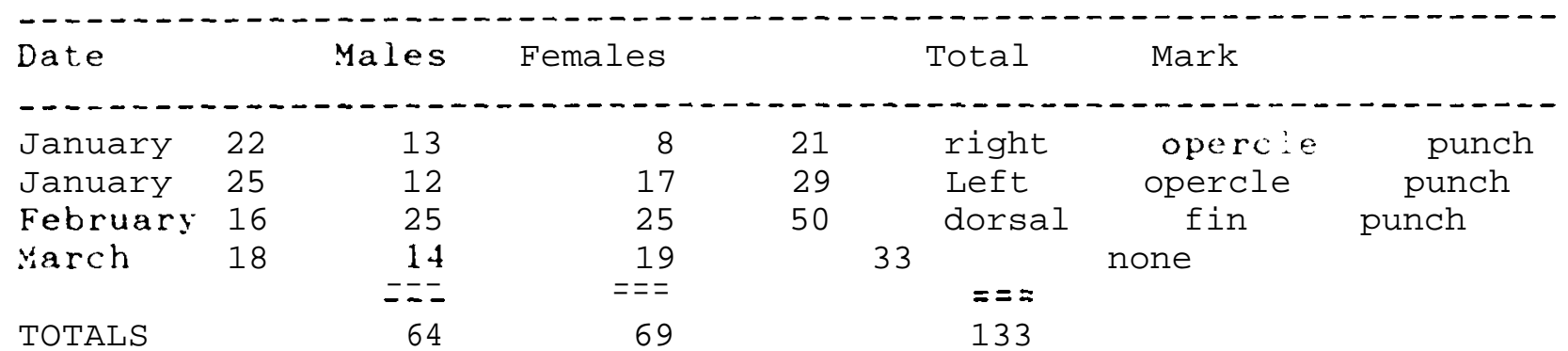

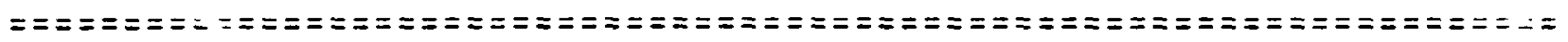
Revised $7 / 22 / 89$

File: $102:$ STCOL $88 \mathrm{~A}$

1/ All adults trapped at Threemile Dam.

No adipose fin-clipped fish were spawned.

All fish transported were held at Minthorn, 


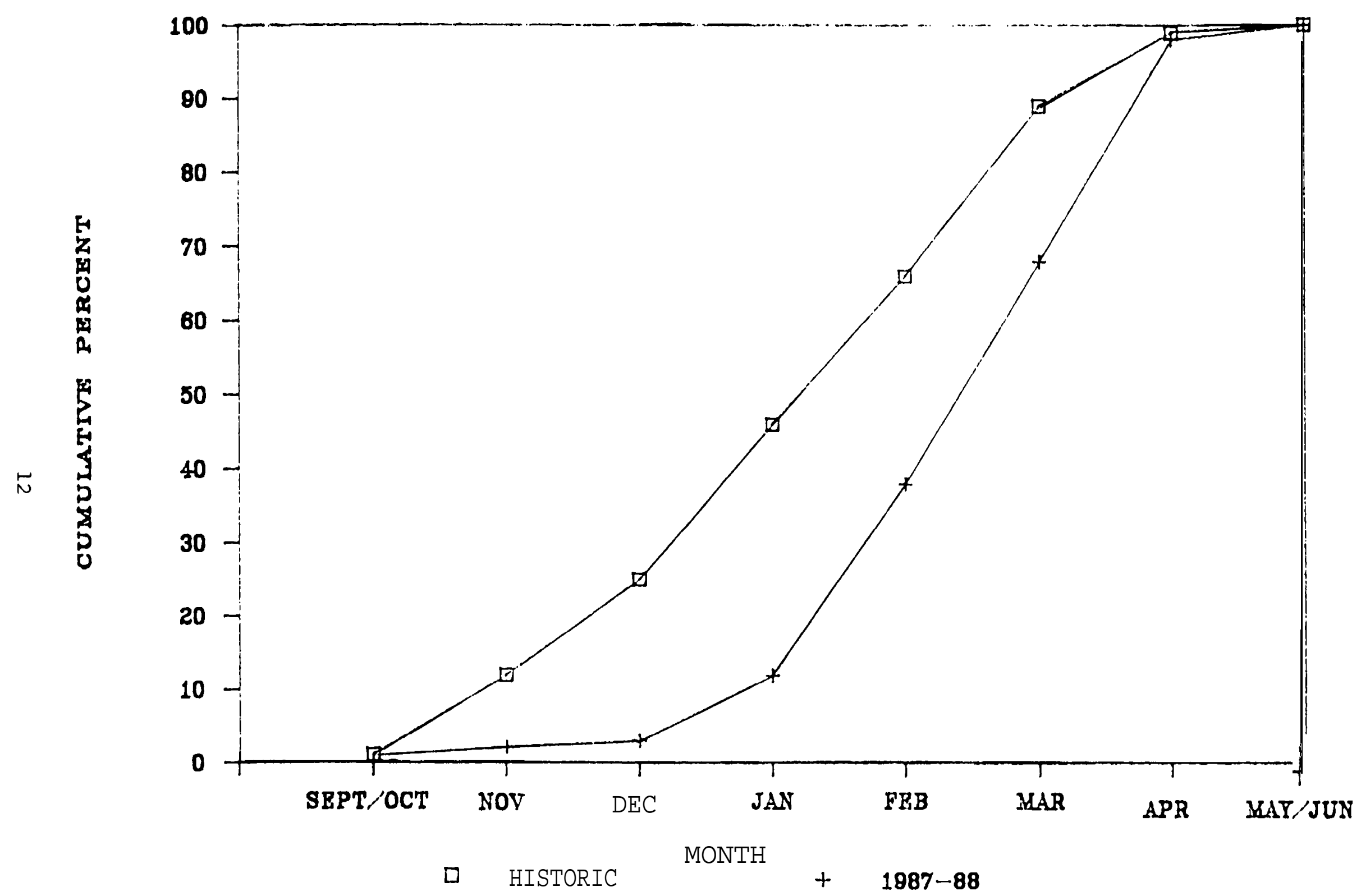

Figure 3. Historic versus 1987-88 run of summer steelhead in the Umatilla River. 
Prespawning mortality during the adult holding period at Minthorn was 39\% (Appendix A). This was much higher than previous years at Bonifer $(24 \% 1987 ; 22 \% 1986 ; 10 \% 1985$; and $8 \% 1984)$, but still less than at McNary Dam before the completion of the acclimation facilities (52\% 1983). A total of 52 adults died prior to completion of spawning in late April. Prespawning mortality was much higher in females (53\%) than in males (26\%). This may have been due to the fact that females were checked for ripeness every spawning (weekly) while males were only handled to the extent needed to find the required number of ripe individuals to pair with females.

-emales at Minthorn (22 which represent $34 \%$ of those collected and $h \in-\lambda$ ) were spawned in addition to nine females collected and spawned at Threemile Dam and an estimated 176,533 eggs were taken (Appendix A). Average fecundity was 5,695 eggs per female. It was not necessary to discard any eggs this year because the results of all IHN and IPN viral samples were negative.

Comparing the percent of spawned fish by month to the distribution of the run by month, it appears that the percentage of spawned fish collected in January was much larger than necessary to have represented the run. About $34 \%$ of the spawned fish were collected in January, whereas only about $10 \%$ of the fish had migrated to the trap by that date (Figure 3). A larger percentage of females collected in January (11 of 25) were spawned compared to those collected in February ( 5 of 25) and March (6 of 19) fish (Appendix B). There was no apparent trend between collection and spawning times. On the first spawning day, two females from each of the collection dates were spawned (Appendix B).

Disease sampling of summer steelhead - Umatilla River 1988 brood

The only fish pathogens detected were spores of Ceratomvxa shasta in 9 of 20 adult mortalities and aeromonad-pseudomonad bacteria in 8 of these same $20 \mathrm{fish}$. None of the pathogens for which tests were performed were detected in fish spawned (Table 2) .

\section{Adult returns to Bonifer}

Two adult steelhead were caught in the trap at Bonifer in 1988. However, 10\% of the adult steelhead captured at Threemile Dam (about 250) had adipose fin clips and are presumed to be from previous Bonifer releases. Several steelhead were observed in Meacham Creek near the mouth of Boston Canyon Creek in March and April. Some of these fish may have been those expected to return to Bonifer, but low flows in Boston Canyon Creek evidently attracted few fish. Two steelhead redds were found in the lower one mile of Boston Canyon Creek this year. None were observed last 
Table 2. Results of disease sampling of summer steelhead spawned and prespawn mortality in 1988 for Umatilla River broodfish.

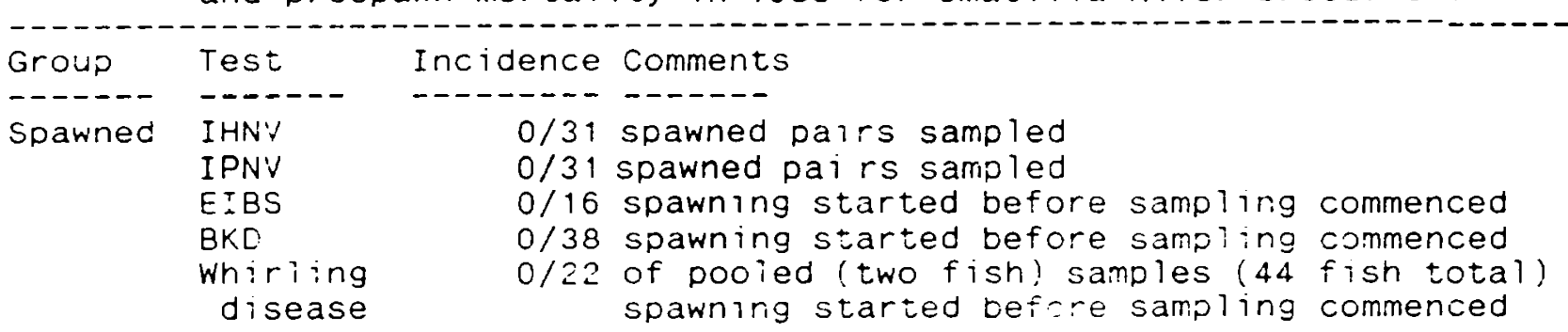

Morts Ceratomyxa $\quad 9 / 20$

shasta

Aeromonas/ $8 / 20$ not at levels $=01$ is ed lethal for fish

Pseudomonas

BKD

$0 / 20$

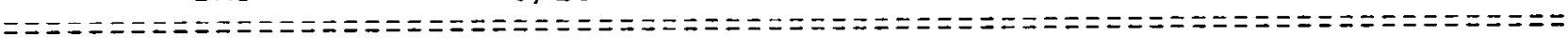
Revised $01 / 05 / 90$ PTL

Filename: 102 : DISES88A

One of the 20 mortalities was collected directly from Threemile Dam.

All other fish were transported and heid at Minthorn Acclimation Facility. Data provided by ODFW Eastern Oregon Fish Pathology Laboratory. 
year, although 8 were observed in 1986 and 10 in 1985. Most adults destined for Boston Canyon Creek from the natural production and hatchery (Bonifer) releases are believed to have spawned in Meacham Creek.

\section{Acclimation and Release of Juvenile salmonids}

Six groups of acclimated juvenile salmonids (353,000 fish) were among the almost 5 million salmon and steelhead released into the Umatilla River in 1988 (Table 3). Fall chinook acclimated in Bonifer and Minthorn in March had two tagcodes for fish at each facility (Table 4). All other acclimated groups were part of facility evaluations, with three tagcodes for each test (acclimated) and control group (unacclimated - kept at the hatchery until release). Fall chinook salmon have been released in the Umatilla River every year since 1982 and from acclimation facilities since 1983 (Table 5). Tule stock fall chinook were initially released in 1982. Since then all releases have been upriver bright stock (Bonneville). This is the third year that spring chinook salmon of Carson stock via Lookingglass Hatchery have been acclimated and released. Summer steelhead of Skamania and Oxbow stocks were released 1967 through 1970. In 1975, one release of Umatilla stock steelhead occurred and fish releases every year since 1981 have been from this stock. Coho salmon were not acclimated this year, but were all released directly into the river (Table 6). Control releases for acclimation studies went into an empty raceway at Minthorn, and in Meacham Creek adjacent to Bonifer.

There were no disease problems during spring acclimation. Both facilities experienced epizootics of Ichthyophthirius (Ich) in the fall. The specific fish losses and treatment are discussed under each acclimation section. Columnaris, which has been encountered in the past, was not a problem at acclimation facilities this year.

\section{Acclimation at Minthorn}

\section{Fall chinook salmon - $\underline{3 / 8}$ to $\underline{3 / 24-25}$}

The first lot of fish held at Minthorn in 1988 was yearling fall chinook salmon (1986 brood) that were reared at Bonneville Hatchery (Table 3). ODFW transferred fish into the facility on $3 / 8$ fish were releases on 3/24-25. Fish of two different tag codes were held together at the hatchery and were not specifically transferred into the upper or lower raceway. Transfer mortality totaled 160 fish while mortality over the 17-day acclimation period was 252 (includes transfer mortality).

Temperature ranged from 5.6 to 10.3 and averaged 7.9 degrees

C (Appendix D). Dissolved oxygen ranged from 7.5 to $13 \mathrm{ppm}$ (Appendix E). Fish in each raceway were fed $0.9 \%$ body weight of food per day. Fish were sampled at $8.8 / 1 b$. just prior to release. 


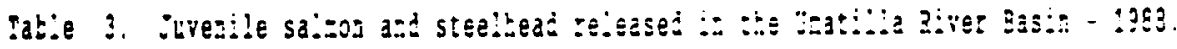

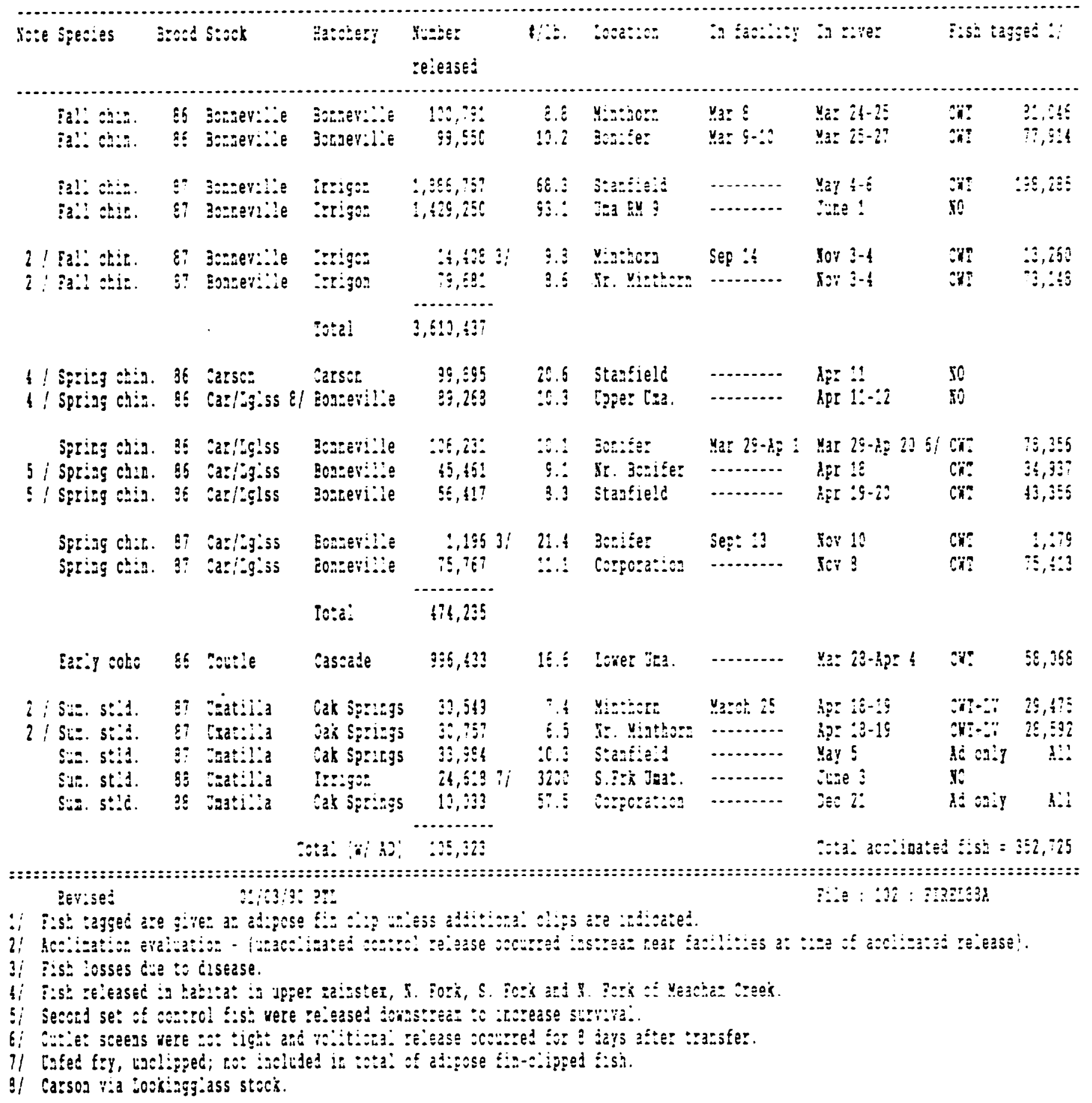


Table 4. Liberation information for fall chinook salmon coded-wire tagged and released in the Umatilla River Basin in 1988.

\begin{tabular}{|c|c|c|c|c|c|c|}
\hline Brood & $\begin{array}{l}\text { Total } \\
\text { number }\end{array}$ & $\begin{array}{l}\text { Release } \\
\text { time }\end{array}$ & $\begin{array}{l}\text { Size } \\
(=/ 1 b .)\end{array}$ & $\begin{array}{l}\text { Sumber } \\
\text { tagged }\end{array}$ & $\begin{array}{l}\text { ChT } \\
\text { code }\end{array}$ & $\begin{array}{l}\text { Release } \\
\text { location }\end{array}$ \\
\hline $\begin{array}{l}86 \\
86\end{array}$ & $=-\begin{array}{r}52,317 \\
48,47 \cdot 4 \\
100,791\end{array}$ & $\begin{array}{l}\text { Mar } 88 \\
\text { Mar } 88\end{array}$ & $\begin{array}{l}8.8 \\
8.8\end{array}$ & $===\begin{array}{r}42,068 \\
38,978 \\
81,046\end{array}$ & $\begin{array}{l}074038 \\
074039\end{array}$ & $\begin{array}{l}\text { Minthorn } \\
\text { Minthorn }\end{array}$ \\
\hline $\begin{array}{l}86 \\
86\end{array}$ & $\begin{array}{r}50,480 \\
49,070 \\
--w- \\
99,550\end{array}$ & $\begin{array}{l}\text { Apr } 88 \\
\text { Apr } 88\end{array}$ & $\begin{array}{l}10.2 \\
10.2\end{array}$ & $==\frac{\begin{array}{l}39,503 \\
38,405 \\
77,914\end{array}====}{}$ & $\begin{array}{l}074036 \\
074037\end{array}$ & $\begin{array}{l}\text { Bonifer } \\
\text { Bonifer }\end{array}$ \\
\hline $8 i$ & $1,886,757$ & Yay 88 & 68.3 & 198,285 & 075007 & Lima RM 23 \\
\hline $\begin{array}{l}87 \\
87 \\
87\end{array}$ & $====\begin{array}{r}1,823 \\
4,660 \\
4,925 \\
14,308\end{array}$ & $\begin{array}{l}\text { Nov } 88 \\
\text { Nov } 88 \\
\text { Nov } 88\end{array}$ & $\begin{array}{l}9.8 \\
9.8 \\
9.8\end{array}$ & $====\begin{array}{r}4,438 \\
4,289 \\
4,533 \\
13,260\end{array}$ & $\begin{array}{l}074539 \\
074540 \\
074541\end{array}$ & $\begin{array}{l}\text { Minthorn } \\
\text { Minthorn } \\
\text { Minthorn }\end{array}$ \\
\hline $\begin{array}{l}87 \\
87 \\
87\end{array}$ & $\begin{array}{r}26,858 \\
25,493 \\
27,330 \\
------ \\
79,681\end{array}$ & $\begin{array}{ll}\text { SOV } & 88 \\
\text { Nov } & 88 \\
\text { Nov } & 88\end{array}$ & $\begin{array}{l}8.6 \\
8.6 \\
8.6\end{array}$ & $===\begin{array}{l}24,656 \\
23,103 \\
25,089 \\
73,148\end{array}$ & $\begin{array}{l}074536 \\
074537 \\
074538\end{array}$ & $\begin{array}{lll}\text { Cma } & \text { RM } & 63 \\
\text { Cma } & \text { RM } & 63 \\
\text { Lima } & \text { RM } & 63\end{array}$ \\
\hline
\end{tabular}


iable 3. Jureaile steelbead and saleon releases in the Oeatille Liver basin - 1900 's $|1|$.

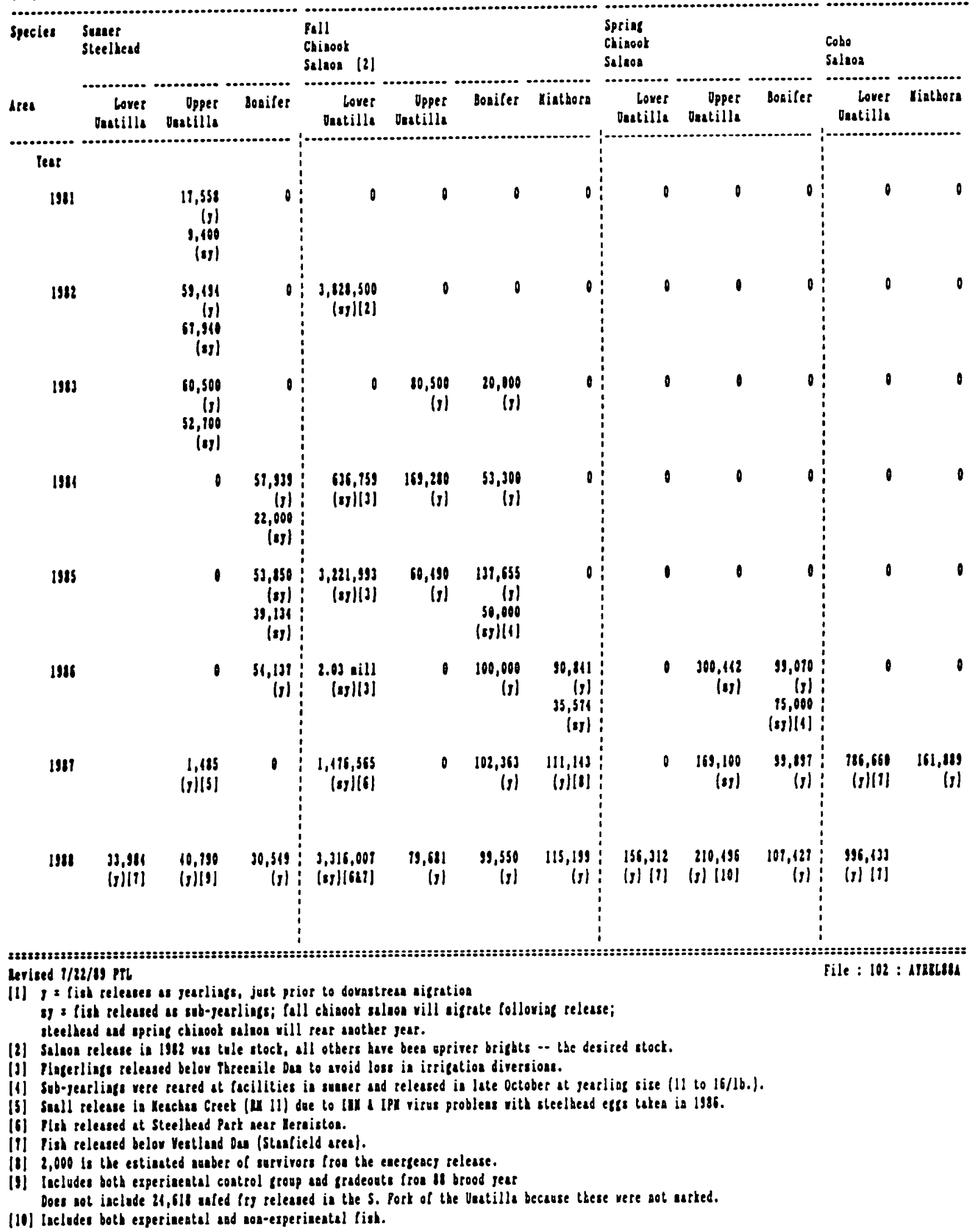




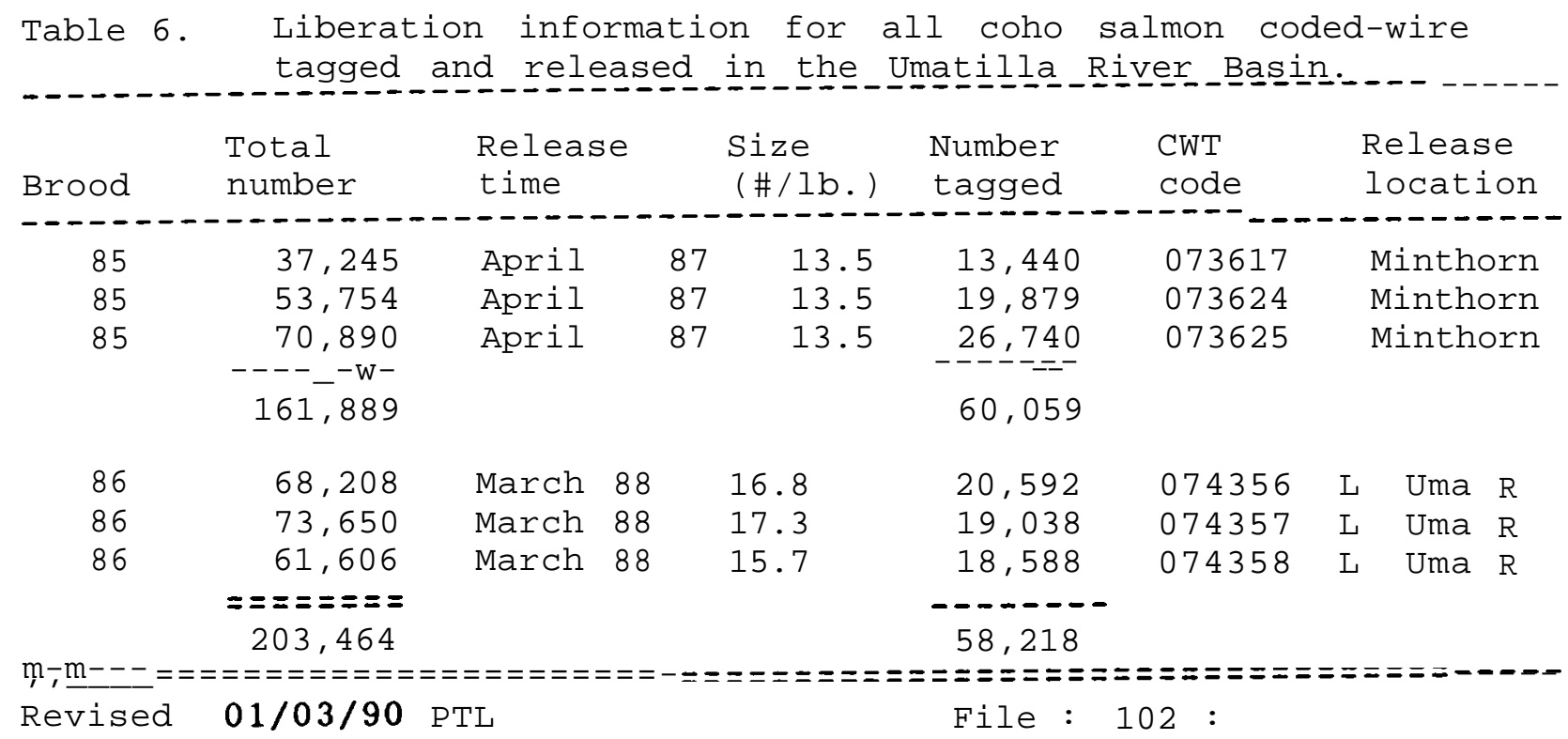


Of the estimated 100,791 fish released, pre-release sampling indicated 81,046 were tagged (Table 4). Length frequencies of marked and unmarked fish were similar to each other (Figure 4). The percentage of fish with total descaling was small, while that of partial descaling was about 54. Marked fish did not appear to have different amounts of descaling compared to unmarked fish (Appendix c).

Summer steelhead $-\underline{3 / 25}$ to $\underline{4 / 18-19}$

The second lot of fish acclimated at Minthorn were 1987 brood summer steelhead from adults spawned at CTUIR acclimation facilities, transferred to Irrigon Hatchery for incubation, and shipped as eyed eggs to Oak Springs Hatchery for hatching and rearing (Table 3). Fish were transferred to the lower raceway on $3 / 25$ and released 4/18-19. These were the first summer steelhead tagged and released into the Umatilla River (Table 7), although hatchery fish have been released since 1967. Transfer mortality was 68 while mortality was 184 (including transfer mortality) over the entire 25-day acclimation period.

During acclimation, temperatures ranged from 5.6 to 13.1 with an average of 9.0 degrees $C$ (Appendix D). Dissolved oxygen ranged from 7.8 to $13 \mathrm{ppm}$ (Appendix E). Fish were fed $0.8 \%$ to $0.9 \%$ body weight of food per day until their release at $7.4 / 1 \mathrm{~b}$. on $4 / 18-19$. Of the estimated 30,549 fish released, pre-release sampling indicated 29,475 were tagged (three tagcodes). A control group of an estimated $30,757 \mathrm{fish}$, with 28,592 similarly tagged fish (three tagcodes), was released at $6.5 / 1 b$. concurrently at the facility as an acclimation experiment (Tables $3 \& 7$ ).

Length frequencies for marked and unmarked fish were not differentiated. The length frequency for acclimated fish was very similar to unacclimated fish (Figure 5). The percentage of partially descaled fish was 1.8 for control fish with almost $70 \%$ of them being partially descaled. Test fish lost fewer scales with essentially no fish being descaled and only 20\% having even partial descaling (Appendix C).

Fall chinook salmon - 9/14 to $11 / 3-4$

The final transfer of fish into Minthorn was 1987 brood fall chinook salmon reared at Irrigon Hatchery (Table 3). Fish were tagged with three different tag codes and were not segregated by raceway (Table 4 ).

Operating procedures at the facility were adjusted according to changes in the availability of the water supply previous to acclimation. Low flows from Minthorn Springs could not sustain the flow necessary to provide $1600 \mathrm{gpm}$ to the raceways. Evidently the drought conditions prevalent in the area affected the springs flows. We recirculated a portion of the raceway outflow for the first time since the facility began operation in 1986 in order to supplement the spring flow and maintain $800 \mathrm{gpm}$ in each raceway. 
Table 7. Literation information for all summer steelhead codea-wire tagged and reieased in the Umatilia River Sasin ir. 1988.

\begin{tabular}{|c|c|c|c|c|c|c|}
\hline Brood & $\begin{array}{l}\text { Total } \\
\text { number }\end{array}$ & $\begin{array}{l}\text { Release } \\
\text { time }\end{array}$ & $\begin{array}{l}\text { size } \\
(\# / 10 .)\end{array}$ & $\begin{array}{l}\text { Number } \\
\text { tagged }\end{array}$ & $\begin{array}{l}\text { CWT } \\
\text { code }\end{array}$ & $\begin{array}{l}\text { Release } \\
\text { iocation }\end{array}$ \\
\hline $\begin{array}{l}87 \\
87 \\
87\end{array}$ & $\begin{array}{c}10,187 \\
10,075 \\
10,287 \\
======= \\
30,549\end{array}$ & $\begin{array}{l}\text { Apr } 88 \\
\text { Apr } 88 \\
\text { Apr } 88\end{array}$ & $\begin{array}{l}7.4 \\
7.4 \\
7.4\end{array}$ & $\begin{array}{r}9,829 \\
9,721 \\
9,925 \\
===== \\
29,475\end{array}$ & $\begin{array}{l}073859 \\
073860 \\
07386 i\end{array}$ & $\begin{array}{l}\text { Minthorn } \\
\text { Minthorn } \\
\text { Minthorn }\end{array}$ \\
\hline $\begin{array}{l}87 \\
87 \\
87\end{array}$ & $\begin{array}{l}10,423 \\
10,171 \\
10,163 \\
======== \\
30,757\end{array}$ & $\begin{array}{l}\text { Apr } 88 \\
\text { Apr } 88 \\
\text { Apr } 88\end{array}$ & $\begin{array}{l}6.5 \\
6.5 \\
6.5\end{array}$ & $\begin{array}{r}9,689 \\
9,455 \\
9,448 \\
====== \\
28,592\end{array}$ & $\begin{array}{l}073356 \\
073857 \\
073858\end{array}$ & $\begin{array}{lll}\text { Uma } & \text { RM } & 63 \\
\text { Uma } & \text { RM } & 63 \\
\text { Uma } & \text { RM } & 63\end{array}$ \\
\hline
\end{tabular}

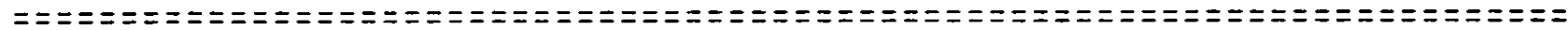
Revised : 


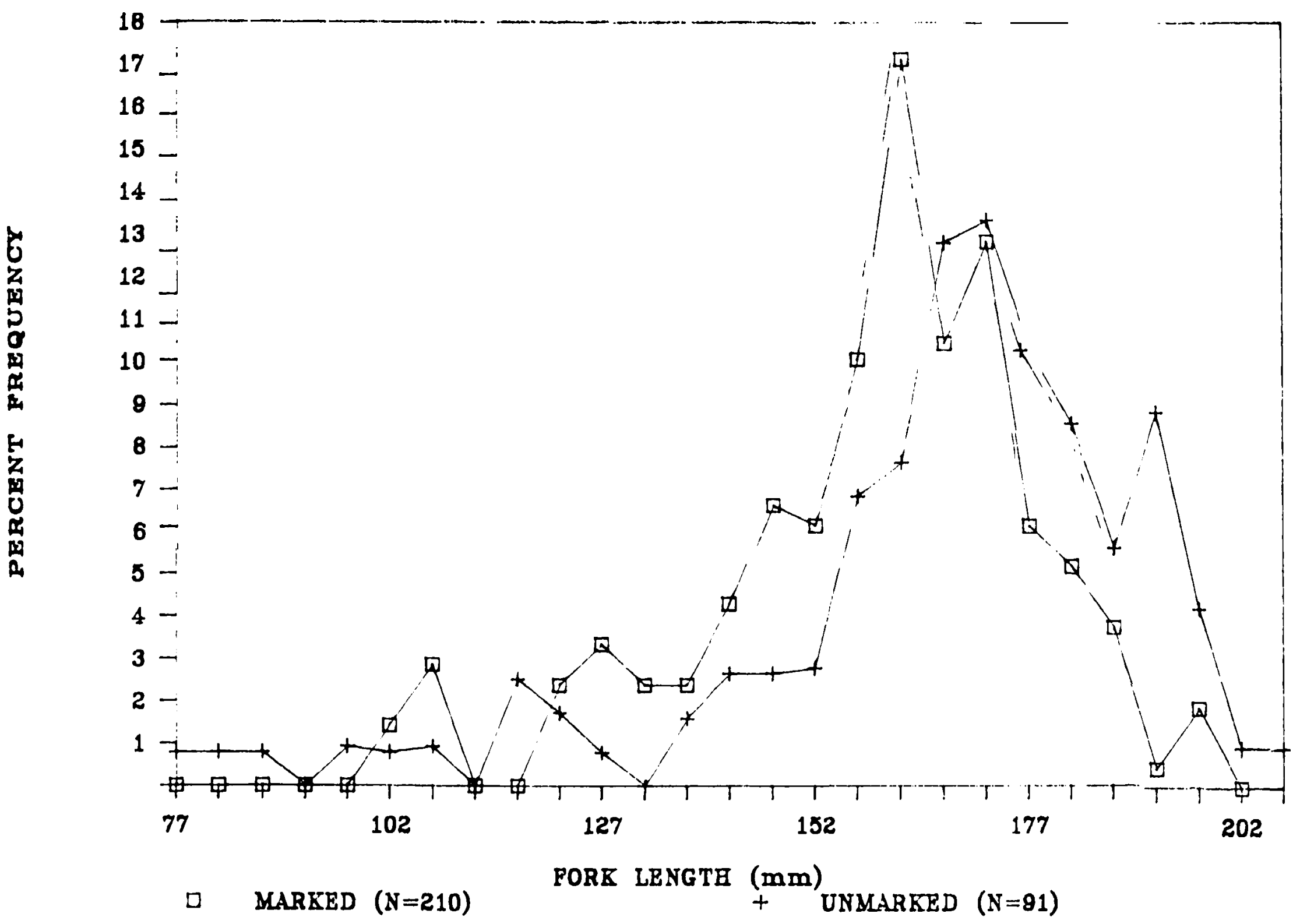

Figure 4. Length frequencies of non-expecimental fall chinook salmon released from Minthorn 3/27-28 - marked versus unmarked. 


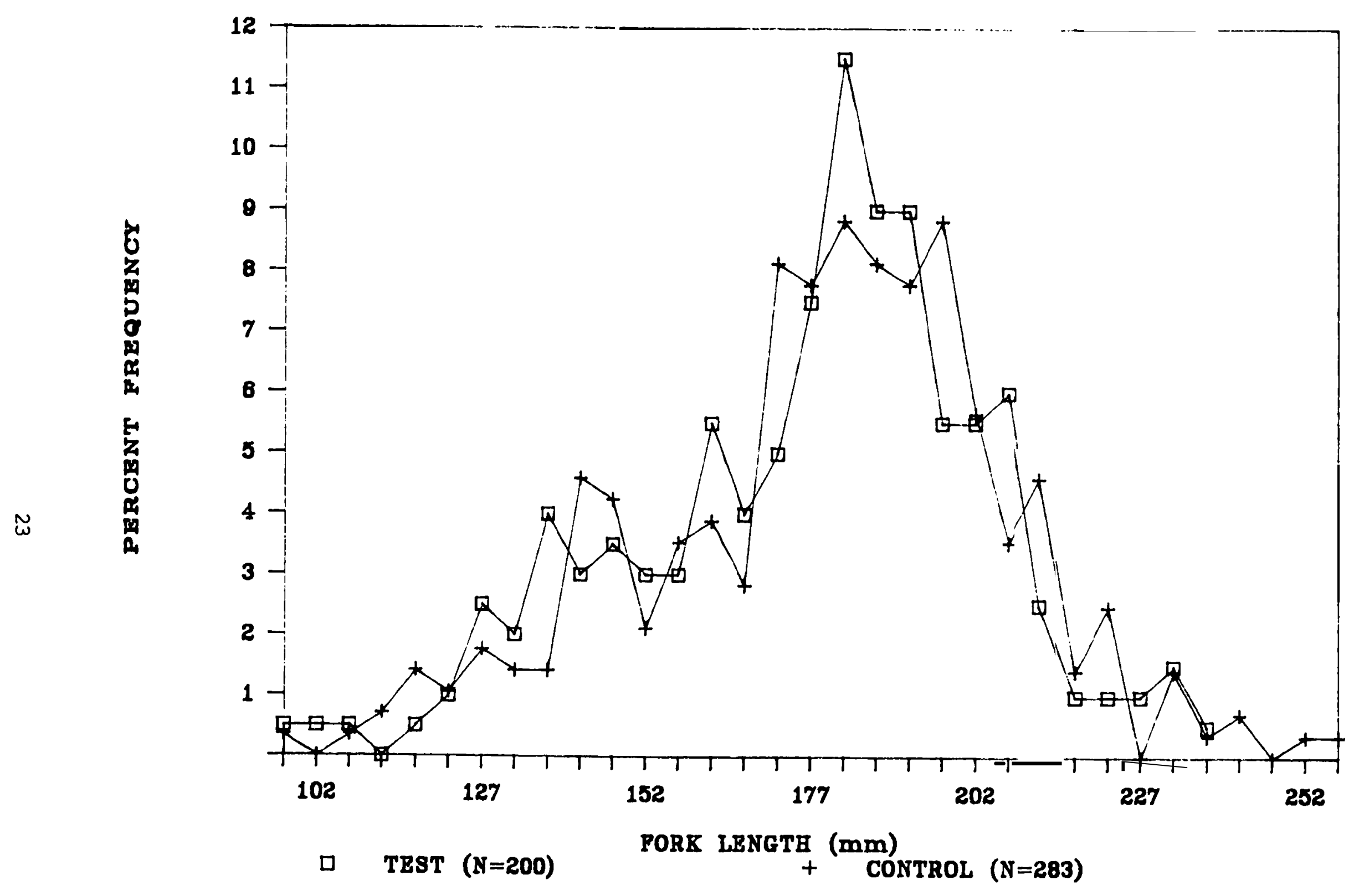

Figure 5. Length frequencies of experimental groups of summer steelhead released at Minthorn 4/18-19 - test versus contral group. 
Dissolved oxygen as low as $6.0 \mathrm{ppm}(6.0-6.6)$ was observed at the pump intake in late July through early september before the acclimation period, however these had returned to above 7.0 by September 8 (Appendix E). Dissolved oxygen readings when the pumps are not being run are slightly below those which would occur in the raceways if the pump was turned on, because some aeration presumably occurs at the head of the raceway. Reuse of water was restricted to the minimum volume necessary to maintain flow of 800 gpm in each raceway.

ODFW transferred fish on $9 / 14$, and they were released $11 / 3-$ 4. Transfer mortality was 192. Fish were fed $1.3 \%$ body weight of food per day.

The DO was above 7.0 on almost every day at the head of both outlets, although it was below this level on two occasions (9/25 and 10/17; Appendix E). The recorded DO at the outlet dipped slightly below 7.0, the level considered safe for salmonids (Leitritz and Lewis 1980) only once during acclimation (both raceways on 9/25). The potential impact of low Do that is not evident in the data should be stressed because 1) these concentrations may not indicate the actual minimums to which fish were exposed and 2) although DC levels were generally above 7.0 ppm at the head of either raceways on all but two occasions, the DO at the outlet was recorded as low as $4.7 \mathrm{ppm}$ and was below 7.0 on 34 occasions (Appendix E).

Except for the previously mentioned notes, acclimation proceeded normally until the weekend of 10/1-2. On these days the fish appeared lethargic, did not feed as well as usual, and mortalities had increased slightly. Additional dead fish were discovered Monday and consequent inspection of some moribund fish revealed pinkish, mucus-clogged gills, with all fish inspected exhibiting small to large extensive areas of necrotic gill tissue. The ODFW Eastern Oregon Fish Pathology Laboratory (NOFPL) in La Grande was immediately notified and arrangements were made to examine moribund fish. Mucus smears and gill examinations revealed a heavy infection of what was diagnosed to be Ichthvonhthirius ("Ich"). Tissue samples and smears ruled out other pathogens. Fish were immediately taken off feed and treatment with formalin was recommended by NOFPL personnel and other ODFW pathologists and hatchery managers. In addition, simple daily flushing has been shown to be effective without chemical use. The severity of the infection prompted CTUIR personnel to use both treatments.

Fish were treated with formalin daily from 1-2 hours at concentrations starting at $1: 7000$ and increasing to 1:5500. Each raceway was flushed daily. An additional treatment for 5 hours at 1:40,000 was added 10/12. Regular treatments (1:5500) were discontinued $10 / 20$ and low-level treatments were continued through 1/26. Flushing was continued until release. After treatment fish were fed $2 \%$ body weight of food per day. 
Most of the mortality was estimated by volume (trash cans and buckets). It was estimated that about 67,000 fish had died and that 11,000 remained.

As health of the fish appeared to improve fish were fed up to $2.0 \%$ body weight of food per day was fed. A sample of fish was examined on $10 / 27$ by Warren Groeberg, NOFPL, and few Ich were found on the gills, while none were detected on the skin. Fish were cleared for release.

Dissolved oxygen during acclimation ranged from 4.7 to $11 \mathrm{ppm}$. (Appendix E). Temperature ranged from 9.3 to 17.1 and averaged 13.6 degrees Celsius (Appendix D).

Length frequencies for marked and unmarked fish were not differentiated. The length frequency for acclimated fish was shifted to the left slightly (Figure 6), as would be expected due lack of feeding just prior to, and during treatment, and as indicated by their smaller average weight. The fish were subsampled at $9.8 / 1 \mathrm{~b}$. just before release on $11 / 3-4$. The percentage of fish with total descaling was less than $1 \%$ for both acclimated and non-acclimated fish, while that of partial descaling was much greater for control fish (Appendix C).

Most fish were counted with a fish counter and the last few were counted by hand. Total was estimated to be 14,408 while sampling indicted the number that were tagged was 13,260. Loss over the 51-day acclimation period was estimated at $82 \%$.

A control group of an estimated 79,681 fish from Irrigon Hatchery was released immediately following the release of the test group at Minthorn. The control fish averaged $8.6 / 1 \mathrm{~b}$. with prerelease sampling indicating 73,148 of these being tagged. Columnaris disease was discovered in control fish at the hatchery while test fish were held at Minthorn. The control group was treated with Terramycin at Irrigon Hatchery, certified and held 10 additional days to clear the Terramycin before release (Table 3).

\section{Acclimation at Bonifer}

Fall chinook salmon - 3/9-10 to $\underline{3 / 25-28}$

The first lot of fish acclimated at Bonifer in 1988 consisted of 1986 brood yearling fall chinook salmon (Table 3). ODFW transferred the fish from Bonneville Hatchery to Bonifer on 3/910 and released 3/25-28. Fish were CWT with 2 tagcodes (Table 4). Transfer mortality was 64 while observed total mortality recorded over the 19-day acclimation period including transfer mortality was 165 fish. Because silt and vegetation cover much of the bottom of Bonifer, observed mortality is not a total count, however few plants had grown by this time and this count was considered 


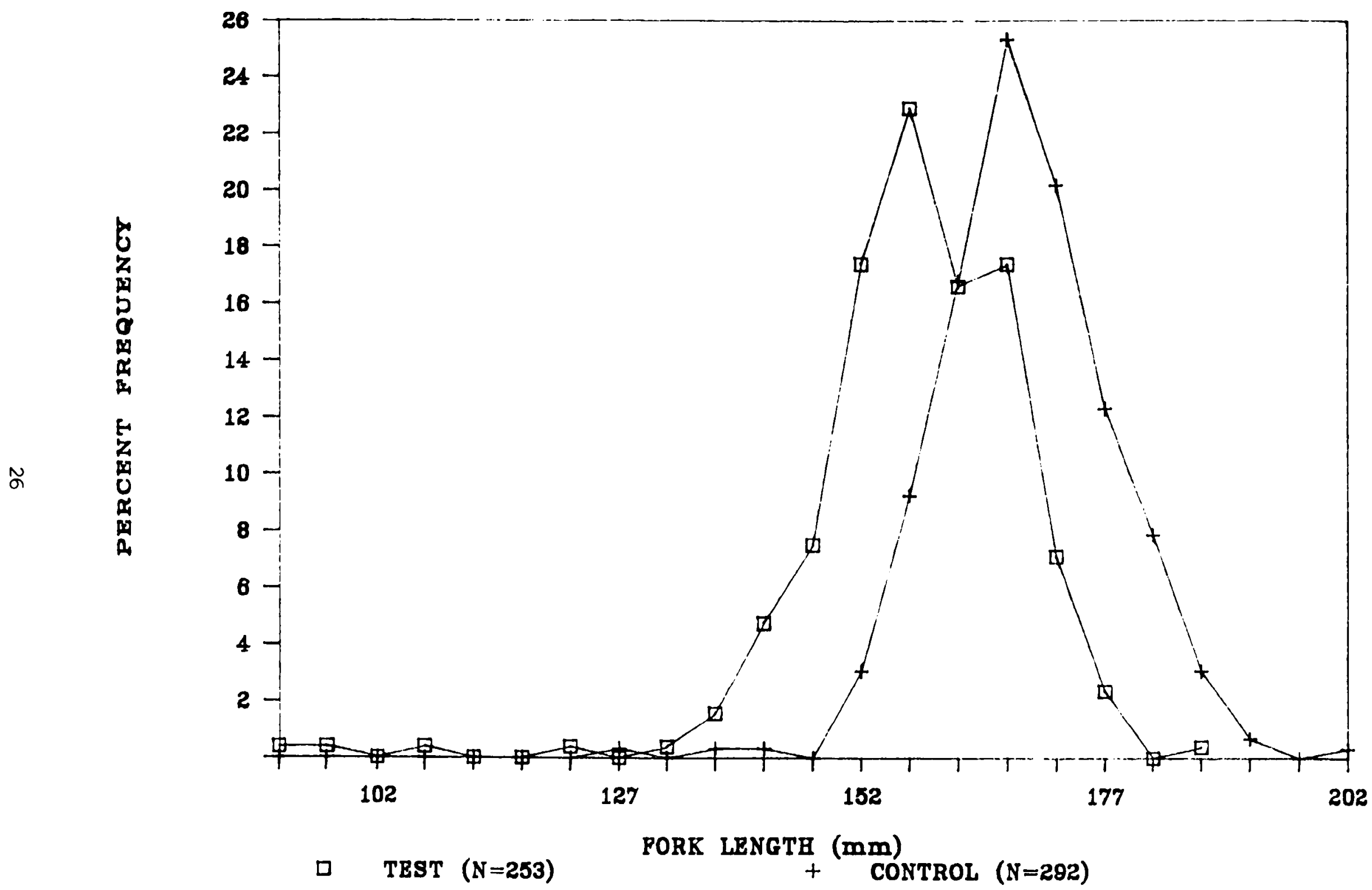

Figure 6. Length frequencies of experimental groups of fall chinook salmon released at Minthorn $11 / 3-4$ - test versus contral group. 
relatively accurate. The small count indicates that heavy mortality did not occur. Temperature during acclimation ranged from 5.0 to 9.7 March 9 to 24, averaging 7.2 degrees Celsius (Appendix F). Dissolved oxygen ranged from 7 to $12 \mathrm{ppm}$. (Appendix G). Fish were fed from 0.9 to $1.0 \%$ body weight of food per day.

A fish counter was installed on $3 / 25$ and it had recorded 55,000 fish by 3/27. Problems with battery terminal connections precluded counting all of the fish. The last few thousand fish had $t n$ be seined/crowded out of the pond on $3 / 27$ because it was not totally drainable after all of the deposition of gravel from Bostor: Canyon Creek at the outlet in past years. The number of fish released was estimated using mortality records.

Fish were sampled just before release on $3 / 25-28$ at $10.2 / 1 \mathrm{~b}$. (Table 3). Of the estimated 99,550 fish that were released, prerelease sampling indicated 77,914 had coded-wire tags (Table 4). No fish were observed in the inlet spring flow or the pond on the morning of 3/28. Stoplogs were replaced to refill the pond. Length frequencies of marked and unmarked fish are similar (Figure 7). The percentage of fish with total descaling was about 3\%, the highest among the six groups acclimated this year. Marked fish did not appear to have different amounts of partial descaling compared to unmarked fish (Appendix C).

\section{Spring chinook salmon $-\underline{3 / 29}=\underline{4 / 1}$ to $4 / 20$}

The second lot of fish acclimated at Bonifer was yearlings from the 1986 brood of spring chinook salmon reared at the Bonneville Hatchery (Table 3). ODFW transferred fish to the Bonifer Facility on $3 / 29-4 / 1$. Test and control groups were each coded-wire tagged with three different tagcodes (Table 8). Transfer mortality was 94 while total mortality was 213. Temperature during acclimation ranged from 6.1 to 13.3 4/7-19, with an average of 9.4 degrees Celsius. Dissolved oxygen ranged from 8.7 to $12.1 \mathrm{ppm}$ (Appendix G). Fish were fed $1.0 \%$ body weight of food per day. On $4 / 6$ it was noted that the screen at the outlet of the pond was not pushed down far enough, and a small gap at the bottom allowed fish to escape. The situation was corrected, and the acclimation continued as normal with the remainder of the fish. However, feeding amounts were reduced following $4 / 6$ and were based on feeding acitivity of the remaining fish.

Size of test fish at pre-release sampling was $10.1 / 1 \mathrm{~b}$. while control fish averaged $8.7 / 1 \mathrm{~b}$. at release (Table 3 ). There is no reason to believe that the number per pound estimate was not representative of fish in the pond. However, given that the test $\mathrm{fish}$ were at $10.15 / \mathrm{lb}$. at transfer and that they were being fed at 1\% body weight, the outmigration of larger fish is a more likely explanation for the small size, rather than a lack of growth. Length frequencies of test and control fish are very similar (Figure 8). Descaling indices did not appear to be different between marked and unmarked fish, although total descaling was over 


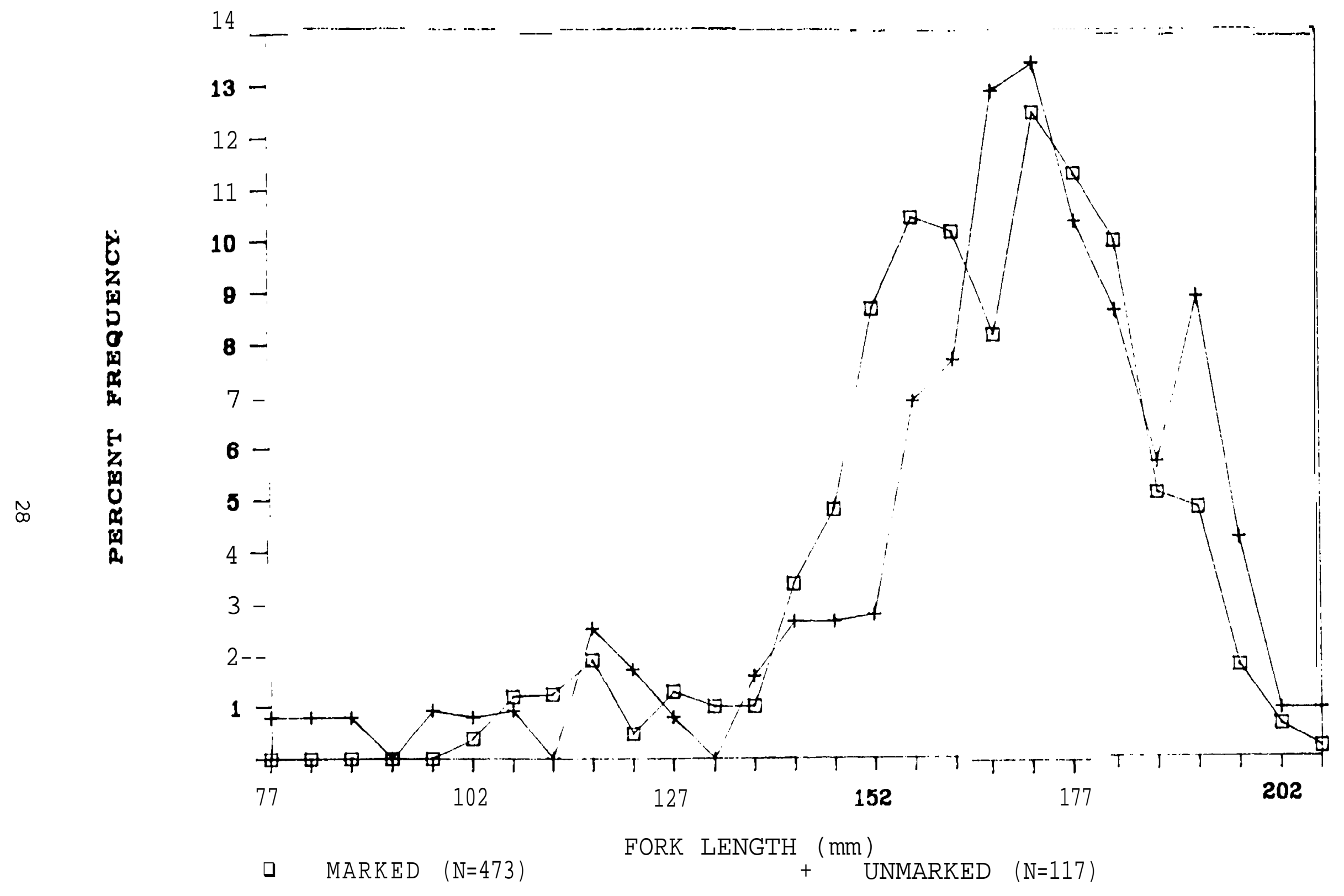

Figure 7. Length frequencies of non-experimental fall chinook salmon released from Minthorn 3/27-28 - marked versus unmarked. 
Table 8. Liberation information for all spring chinook salmon coded-wire tagged and released in the Umatilla River Basin.

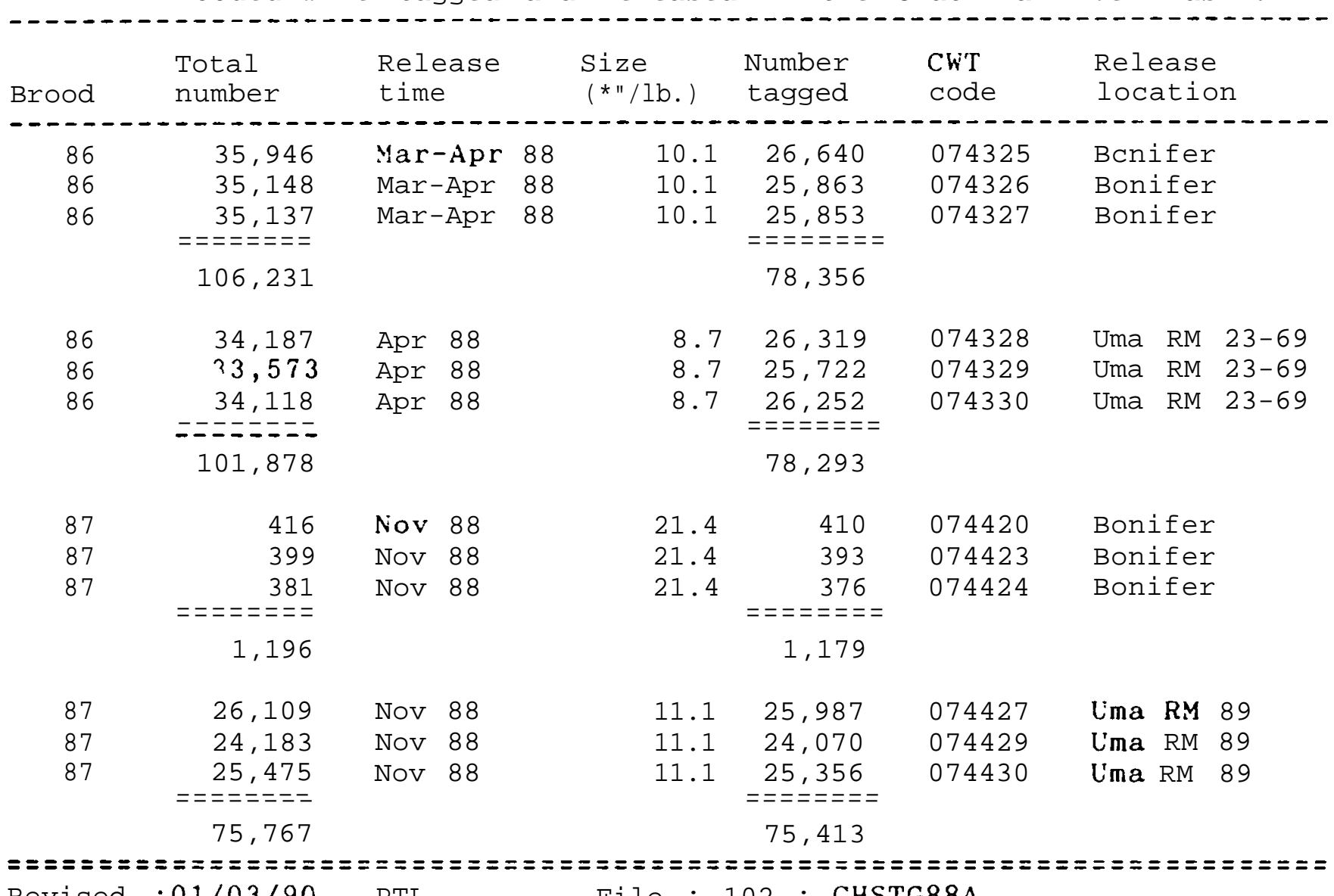

File : 102 : ChSTG88A 


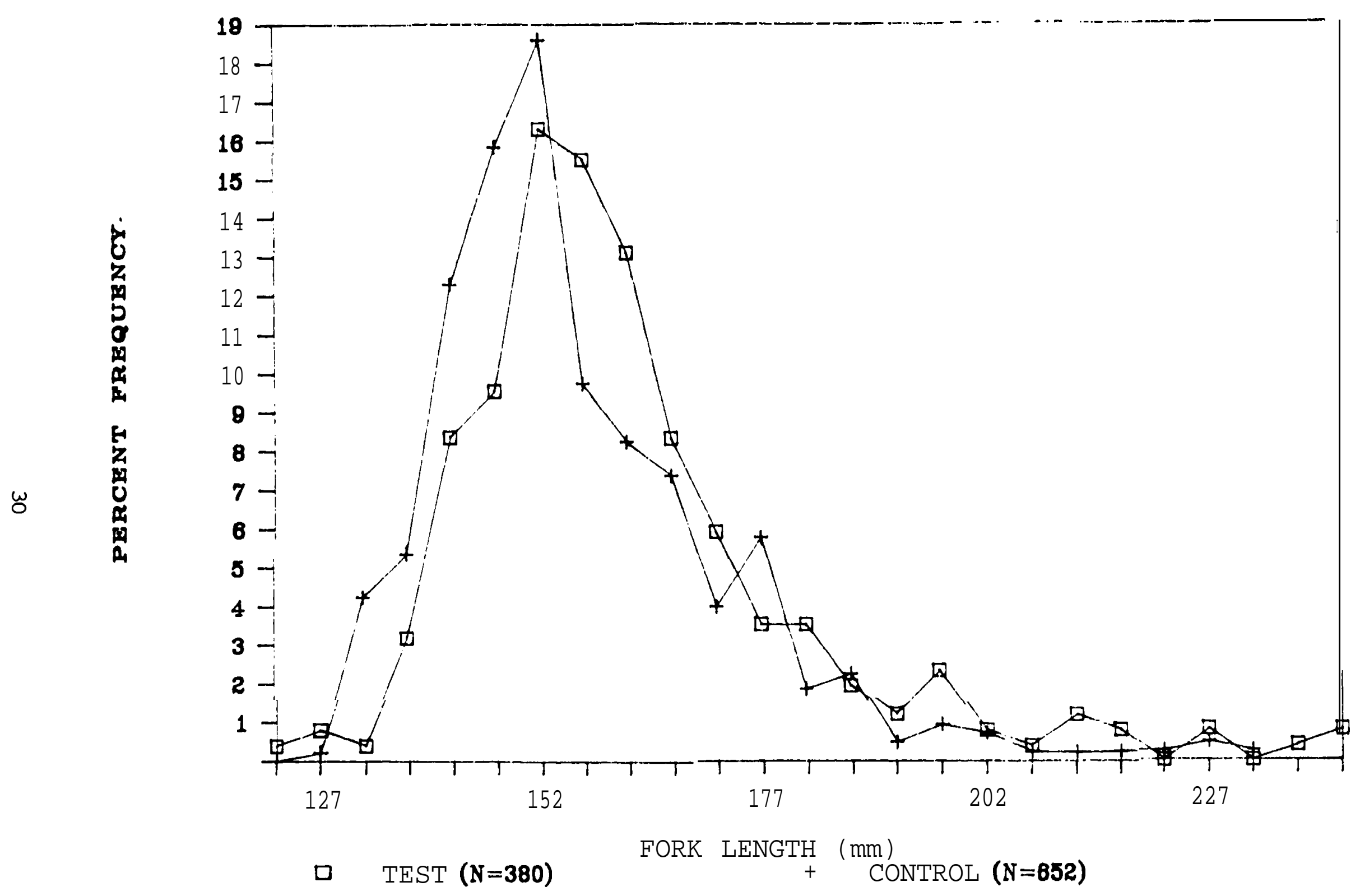

Figure 8. Length frequencies of marked experimental spring chinook salmon released at Bonifer and in the lower Umatilla River 3/29-4/30

-test versus control group. 
1\% in the test fish. Partial descaling was actually lower in the test fish (Appendix C).

A counter was installed on $4 / 19$ to determine the approximate number of fish that remained in the pond. On 4/20 the remainder of the fish (about 12,000) were seined and crowded through the counter. Flow in the Umatilla River was dropping dramatically. After releasing the first group of control fish $(45,461)$ on April 18, flow appeared to be heading for a drastic reduction and it was questionable as to whether the acclimated fish and the newlyreleased control fish would have adequate flow for a successful migration. The validity of a true test of acclimation was assessed at that time. The decision was made to scrap the experiment due to the unknown acclimation time and number of the majoirty of test fish and the desire to maximize the survivial of the rest of the control group which would be jeopardized severly by relesing them above Westland smolt trap. The remainder of the control fish $(56,417)$ were released at Stanfield in the lower Umatilla River (Table 3).

\section{Sprina chinook salmon - $9 / 13$ to $11 / 10$}

The third lot of fish acclimated at Bonifer was subyearlings from the 1987 brood of spring chinook salmon reared at the Bonneville Hatchery (Table 3). ODFW transferred fish to the Bonifer Facility on 9/13. Test and control groups were each codedwire tagged with three different tagcodes (Table G). Transfer mortality for the test group was 18. Temperature during acclimation ranged from 8.5 to 16.9 , with an average of 13.3 degrees Celsius during the 58-day acclimation (Appendix F) Fish were fed $1.4 \%$ body weight of food per day until 10/14.

The potential for low Do may often be present at Bonifer as plants start to die off in late summer and early fall. Low DO was observed in August, but seemed to improve by the week before transfer. Breakdown of accumulated organic material at the outlet caused extreme depletion (<5 mg/l) of oxygen shortly after fish were transferred on $9 / 17$ and several times thereafter (Appendix G). Fish evidently avoided the area next to the outlet. Oxygen concentrations to which fish were subjected are more accurately reflected by readings recorded at a stake anchored in the middle of the pond. It must again be emphasized that DC measurements at Bonifer were rarely taken before 10:00 a.m., and probably do not reflect the minimum oxygen to which fish were exposed.

On 10/15, the technician noted a large number of mortalities and many lethargic fish in the shallows. Inspection of the fish revealed a heavy infection of Ich, with a few parasites already visible on the skin. Fish were taken off feed and a low-level fonnalin treatment $(24-\mathrm{H}$ at $1: 40,000)$ was begun after inspection of the fish and confirmation of "Ich". On $11 / 4$ we decided to go with a heavier $(1: 15,000)$ treatment for a shorter period of time

$(12 \mathrm{hr})$ because we were having trouble getting drippers to work all night. This allowed us to be at the site for most of the 
treatment, so that we could monitor the three drippers at each inlet more carefully. Examination of a sample of fish at Bonifer on $11 / 8$ by the project biologist revealed that the number of Ich per gill arch was very low. After consultation with Warren Groeberg, it was decided to release the remaining fish.

Retrieval of mortalities at Bonifer was very difficult due to thick algal and aquatic macrophyte beds. Upon release fish were counted with an electronic counter (the last few were counted by hand). The release count of 1,196 fish indicated 98\% mortiality had occurred.

Fish were released on $11 / 10$ at $21.4 / 1 \mathrm{~b}$. Of the estimated 1,196 fish released, pre-release sampling indicated 1,179 were tagged. Because so few test fish survived acclimation, control fish were treated as production $\mathrm{fish}$, and were at released on 11/10 at Corporation instead of next to Bonifer. Of the 75,767 control fish released (at $11.1 \mathrm{fish} / \mathrm{lb}$ ), 75,413 were tagged. Length frequencies of samples of test and control fish are somewhat different (Figure 9). The smaller size of the test fish was most likely due to disease, lethargic feeding and total abstinence during treatment. The percentage of fish with severe descaling was zero, while that of partial descaling was very similar between test and control groups (Appendix C).

Outmigration Monitoring

Data were collected at the juvenile salmonid trap (Westland). Extensive overlap in the length frequencies of various release groups at release precluded use of length frequency as a reliable methods to distinguish group at the juvenile trap. Peaks in daily rates suggest that fish can migrate to the trap from release facilities as quickly as 2-3 days, as seems the case for releases in late March. The trend did not hold up for the releases around the 20th of April. The number of fish declined (probably due to prevailing drop in flow) and did not pick up again until mid-May. Trap counts seem to suggest that the majority of fish in the system migrated in May (Appendix $\mathrm{H}$ ).

Assessment of Acclimation Facilities

Temperatures and D.O. measurements that were recorded at the acclimation facilities are reported with associated acclimation periods and in Appendices $D$ and $F$.

Fish Management Consultants met with Tribal Biologists several times before, during and after the biological evaluation of Bonifer was complete. They were contracted to:

1) review documents related to past operations,

2) determine data needs beyond those data already being collected,

3) complete a field survey of the pond and its spring sources, 


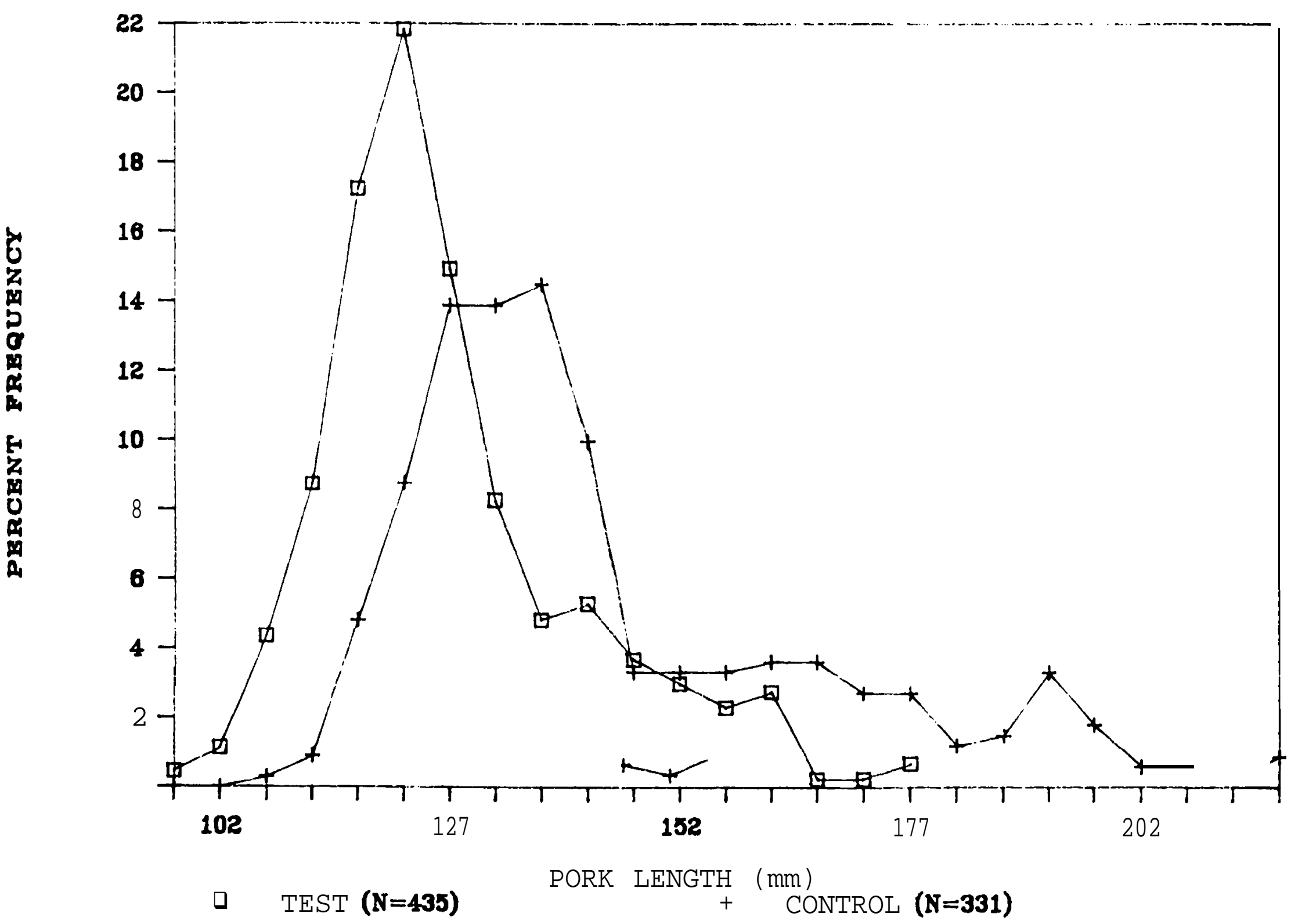

Figure 9. Length frequencies of experimental groups of spring chinook salmon released at Bonifer $11 / 8-10$ - test versus control group- 
4) coordinate design at the Bonifer outlet in Boston Canyon Creek with an ongoing Habitat Project,

5) observe daily operations,

6) become familiar with current procedures and structures relating to fish release,

7) in cooperation with CTUIR, collect data necessary for analysis of the system, and

8) submit a draft and final report detailing recommendations.

Their recommendations were presented in two parts. The first recommendations were to provide for efficient evaluation and culture operations. This included:

1) annual removal of gravel at the outlet,

2) annual control of aquatic vegetation,

3) removal of resident fish,

4) standby oxygen,

5) automatic feeders,

6) fish counter,

7) grading and reshaping of the pond,

8) installation of fish barriers and a

9) metal storage building.

The other recommendations were to optimize production capability. These were:

1) cleaning of the ditches through which the springs flow,

2) supplementing of spring flow with water from Boston Canyon Creek,

3) build an adult holding pond,

4) build two 6,000 cubic foot raceways for acclimation,

5) eliminate leakage around the fishway,

6) provide the ability to bypass spring water.

Details of the biological analysis and recommendations were provided in a final report to BPA entitled "Review of Bonifer Spring culture operation with recommendations" (Jan 1989). CTUIR and BPA are in the process of discussing how these biological recommendations mesh with overall production goals, and which options provide the best method to reach these goals.

FMC will be conducting an evaluation of Minthorn in 1989 similar to that completed at Bonifer.

Acclimation Research

\section{Taqaina - Subcontract}

A test group of fall chinook salmon consisting of three replicates totaling $82,243 \mathrm{fish}$ was tagged in May and acclimated at Minthorn in the fall. A control group consisting of three replicates totaling 80,591 fish was tagged and released directly into the stream near Minthorn at the time of the acclimation release (Appendix H). 
Four groups of spring chinook salmon were tagged in August for the study. A test group consisting of three replicates totaling 77,049 fish was tagged and acclimated at Bonifer in the fall. The control group consisting of three replicates totaling 75,797 fish was tagged and was to be released directly into the stream at the time of the acclimation release (Appendix $\mathrm{H}$ ). These fish ended up being treated as a production group, and were released upstream at Corporation instead (Table 3).

A test group of spring chinook salmon consisting of three replicates totaling 79,497 fish was tagged and will be acclimated at Bonifer in the spring of 1989. A control group consisting of three replicates totaling 80,884 fish was tagged and will be released directly into the stream at the time of the acclimation release (Appendix $\mathrm{H}$ ).

Two groups of summer steelhead were tagged for the study in October. A test group consisting of three replicates totaling 30,271 fish was tagged and is to be acclimated at Minthorn and released in 1989. A control group consisting of three replicates totaling 30,266 fish was also tagged and will be released directly into the stream at the time of the acclimation release (Appendix H).

\section{Adult returns to Threemile Dam}

The snouts from fall chinook salmon with adipose fin clips were collected at Threemile Dam in the 1987-88 season. Taken from the trap were 157 subjacks, 14 jacks and 14 adults. Additional fish snouts from fall chinook salmon were also provided through a BIA-funded spawning survey conducted below Threemile Dam. Not all fish that returned to the Umatilla River made it to Threemile Dam trap. Spawning was observed in a few gravelly areas between the mouth and the dam. Snouts were collected from 1 subjack, 1 jack, and 5 adults. Size categories for all of these fish were defined as <458mm for subjacks, 458-609 for jacks and > 609 for adults. The cutoff for subjack size was determined by CTUIR biologists who examined the length frequency information for the fall chinook salmon run in 1987. Snouts were turned over to ODFW for tag identification. Data from ODFW are not currently available for fish from this season.

Data were available for the 73 tags that were retrieved from fall chinook salmon in the 1986-87 season. One jack (637 mm) was released from Bonifer or the upper Umatilla River in March of 1985. Two jacks (482 \& $484 \mathrm{~mm})$ were also released from Bonifer or the upper Umatilla River, but in June of 1985. All 70 of the subjacks were released from Bonifer or Minthorn in March of 1986. 
Project Difficulties

operational problems at Bonifer

Complete drainage of Bonifer Pond was a problem again this year. Yearly bedload movement from recently destabilized banks continues to fill in the area surrounding the outlet at Bonifer. As in previous years, some juveniles migrated into the main feeder spring from Bonifer. Although a "barrier" (cobble dam) across the spring entrance remained intact, fish were seen in the ponds above the entrance of the main spring. In 1989 a small barrier will be constructed in an effort to prevent this movement.

This year the growth of aquatic vegetation at Bonifer proved to be more than a simple nuisance. Deteriorating material in the pond from spring and summer growth severely depleted oxygen during fall acclimation. Low dissolved oxygen probably stressed fish being acclimated in the fall, thus exposing weakened fish to the Ich parasite and predisposing them to a disease outbreak (Pers. comm. Warren Groeberg, ODFW)

Food and Feeding

Length frequencies suggest that acclimated fish are not shorter than control fish at release. However, estimates of number per pound do suggest that test fish regardless of the group, weigh less. This translates to fish that lease the acclimation facility with a lower condition factor. Fat reserves that are associated with high condition factors in hatchery - reared juvenile salmonids may be a key to success in some groups. In addition, if test fish go out at a smaller size (weight) this effect on their survival could complicate testing of differences in survival due onlv to acclimation.

An effort must be made to ensure that the test and control groups are as close to the same size as possible. Hatchery managers and CTUIR personnel must make a concerted effort to achieve this goal. When hatchery managers have a standard feed (e.g. 1.0 body weight/day) it will be easy for CTUIR personnel to feed something near the equivalent for their water temperature. But when a manager feeds them as much "as they'll eat" to get them to size CTUIR personnel need to know what that amount is in order to duplicate it and prevent fish from leaving acclimation facilities being over or underfed.

\section{Disease}

Bonifer and Minthorn have never had disease problems with spring acclimation. Fall acclimations have been plagued by epizooties of Ich, and Columnaris. In the fall, DC at both facilities tends to drop. It has been suggested by pathologists that the presence of Ich and Columnaris, coupled with stressors (low DO), may produce a situation where the occurence of an 
epizootie will be a chronic problem. Columnaris, although it has been present has not been as much of a problem. Recommendations of pathologists are the same as those recommended by FMC at both Bonifer and Minthorn. Generally speaking they are 1) clean up the environment (fish above the facilities which may be carriers and sources of reinfection, and 2) improve water quality (most specifically the chronic low DO). Until these problems are solved, pathologists recommended not having a full-blown acclimation at Bonifer in the fall. Acclimation at Minthorn could proceed with caution only because there is a controlled environment, and fish could be treated if an outbreak should occur. In addition, close daily monitoring of fish at Minthorn should be completed to detect Ich early to avoid potential losses. If Ich appear start treatment immediately. Most of the concern of the pathologists is realization that the facilities should not be planned to run like this in the future. Either the problems need to be fixed (bottled $\mathrm{O}^{2}$, packed columns, etc.) or the option of not using the facilities in the fall should be considered.

\section{Operational problems at Minthorn}

Extra effort to clean the pump intake prevented clogging which has occurred in the past. Problems with the configuration of the alarm system were corrected in the fall (see Facility Maintenance).

Problems with low Do at Minthorn probably contributed to the outbreak of Ich at Minthorn in the fall. Evaluation of Minthorn to examine this and other problems associated with Minthorn operations should be able to suggest solutions to this problem.

\section{Electronic thermographs}

Apparent malfunctions caused some water temperature data to appear in error (e.g. $20 \mathrm{C}$ at Bonifer in February). No apparent reason could be given for this, and the thermograph appeared to function normally thereafter. Care must be taken when drawing water down in areas where thermograph probes are stationed to make sure ambient air temperatures are not confused with water temperatures.

Research problems

Documenting the number of fish released at Bonifer has been a recurrent problem. The number of fish transferred into the facility is available through hatchery records. In 1988, mortality during spring acclimations was very low, and recorded mortality was probably not much less than actual mortality. However, when disease and other problems caused large losses (e.g. fall acclimation), the number of fish that were released was difficult to estimate and was subject to an unquantifiable error. Use of the fish counter will be most effective when the pond can be completely drained. Incomplete drainage necessitates crowding the fish through the counter (causing a potential for an inaccurate count and unnecessarily stressing fish) and seining of the remainder of 
the fish (a labor intensive and stressful endeavor). Extensive aquatic macrophyte growth in the spring and fall made retrieval of mortalities difficult and clogged the fish counter.

Information on the outmigration of particular releases has been very difficult to determine. Multiple releases make it difficult to distinguish between acclimation groups, test and control groups and subspecies (chinook salmon of similar sizes). Work to be completed at Threemile Dam in 1909 will allow sampling of juveniles at a place other than wastland. When research for acclimation facilities is incorporared i: o Umatilla Hatchery Master Plan, groups of fish will be freeze-pranded so that they can be distinguished at collection facilities on the Umatilla and the mainstem Columbia River. 


\section{IITBRATURE CITED}

Confederated Tribes of the Umatilla Indian Reservation (CTUIR). 1988. Draft Report: Columbia Basin System Planning, Umatilla Subbasin, October 31, 1988. Submitted to Northwest Power Planning Council and Columbia Basin Fish and Wildlife Authority.

Fish Management Consultants. 1988. Draft Report: Review of Bonifer Springs culture operation with recommendations. Report submitted to Bonnevilie Power Administration. 53pp.

Leitritz. E. and R. C. Lewis. 1980. Trout and salmon culture (Hatchery Methods). California Fish Bulletin \#164. University of California, Berkeley. 197pp.

Scully R.J., E. Buettner and C. Cummins. 1984. Smolt condition and timing of arrival at Lower Granite Reservoir. Report Submitted to BPA for Project No. 83-323B. $87 \mathrm{pp}$. 
Appendix A Steelhead broodstock spawning and prespawn mortality at Minthorn Acclimation faci i ity and Threenile Dan in 1988.

Faniiy Sex co?:yark Date Fork Hypural Weight Fecundity Date Prespawn group coll length l ength (lbs) 3/4/ spawned mortality/6 $1 /$ (na) (nn) 21

Eg take H F T

\begin{tabular}{|c|c|c|c|c|c|c|c|c|c|c|}
\hline \multirow{3}{*}{$\begin{array}{l}1 \\
2\end{array}$} & & $F$ & $1 \mathrm{HH}$ & $3 / 19$ & $x$ & 550 & 4.2 & 6,696 & $3 / 31 / 88$ & 57 D \\
\hline & H & & $2 \mathrm{RO}$ & ID2 & 630 & 500 & 4.6 & & & \\
\hline & & $F$ & 3 ما & $1 / 25$ & 780 & 200 & 83 & 7,052 & & \\
\hline 2 & H & & ما 4 & $1 / 25$ & 20 & 500 & 4.2 & & & \\
\hline \multirow[t]{2}{*}{3} & & $\mathrm{f}$ & 5 to & $1 / 25$ & 700 & 580 & 56 & $?, 128$ & & \\
\hline & H & & 6 ما & $1 / 25$ & 660 & 520 & 51 & & & \\
\hline \multirow[t]{2}{*}{4} & & i & $7 \mathrm{NH}$ & $3 / 18$ & 580 & 490 & 35 & 4,284 & & \\
\hline & $H$ & & ما 8 & $1 / 25$ & 650 & 520 & 56 & & & \\
\hline \multirow[t]{2}{*}{5} & & $F$ & $9 \mathrm{RO}$ & $1 / 22$ & 590 & 480 & 35 & 4,950 & & \\
\hline & H & & $10: 0$ & $1 / 25$ & 740 & 590 & 7.1 & & & \\
\hline \multirow[t]{2}{*}{5} & & $\mathrm{~F}$ & 11 DP & $2 / 16$ & 730 & ๓ & 63 & 6,808 & & \\
\hline & H & & 12 LO & $1 / 25$ & 750 & 60 & 7.9 & & & \\
\hline \multirow[t]{2}{*}{1} & & $F$ & $13 \mathrm{DP}$ & $2 / 16$ & 550 & 460 & 31 & 3,188 & & \\
\hline & H & & $14 \mathrm{RO}$ & $1 / 22$ & 20 & 490 & 4.7 & & & \\
\hline \multirow[t]{2}{*}{8} & & $F$ & $15 \mathrm{RO}$ & $1 / 22$ & 60 & 550 & 57 & 5,983 & & \\
\hline & M & & $16 \mathrm{DP}$ & $2 / 16$ & 790 & 60 & 9.2 & & 46,089 & \\
\hline \multirow[t]{2}{*}{9} & & $F$ & 17 NM & $3 / 18$ & $x$ & 500 & 4.1 & 3,696 & $4 / 7 / 88$ & 3912 \\
\hline & $n$ & & $18 \mathrm{NH}$ & $3 / 18$ & 28 & 20 & 9.1 & & & \\
\hline \multirow[t]{2}{*}{10} & & 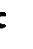 & $19 \mathrm{NM}$ & $3 / 18$ & 730 & 580 & 61 & 1,752 & & \\
\hline & H & & $20 \mathrm{DP}$ & $2 / 16$ & 600 & 530 & 50 & & 11,448 & \\
\hline \multirow[t]{2}{*}{11} & & F & $21 \mathrm{RO}$ & $1 / 22$ & $\mathbf{x z}$ & 580 & 63 & 6,475 & $4 / i 4 / 88$ & $68 \mathrm{H}$ \\
\hline & $M$ & & $22 \mathrm{LP}$ & $2 / 16$ & 88 & 50 & 5.1 & & & \\
\hline \multirow[t]{2}{*}{$D$} & & $=$ & 23 LO & $1 / 25$ & 70 & 590 & 53 & 6,600 & & \\
\hline & $M$ & & $24 \mathrm{MM}$ & $3 / 18$ & $2 *$ & 540 & 56 & & & \\
\hline \multirow[t]{2}{*}{$B$} & & F & 25 LO & $1 / 25$ & œ0 & 50 & 39 & 5,148 & & \\
\hline & M & & $26 \mathrm{DP}$ & $2 / 16$ & 800 & 640 & 9.5 & & & \\
\hline \multirow[t]{2}{*}{14} & & $=$ & $27 \mathrm{RO}$ & $1 / 22$ & 590 & 480 & 3.2 & 6,094 & & \\
\hline & $H$ & & $28 \mathrm{DP}$ & $2 / 16$ & 640 & 530 & 61 & & & \\
\hline \multirow[t]{2}{*}{15} & & $=$ & 29 to & $1 / 25$ & $8 x$ & 450 & 24 & $3,: 58$ & & \\
\hline & $M$ & & $30 \mathrm{DP}$ & $2 / 16$ & 790 & 640 & 87 & & 21,485 & \\
\hline 16 & 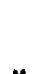 & i & $31 \mathrm{DP}$ & $2 / 16$ & 640 & 520 & $x * x$ & 5,400 & $4 / 21 / 88$ & 145 \\
\hline \multirow{2}{*}{$! 1$} & M & 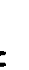 & $\begin{array}{l}32 \mathrm{RO} \\
33 \mathrm{PP}\end{array}$ & $1 / 22$ & 20 & 500 & 218 & & & \\
\hline & H & & $34 \mathrm{MM}$ & $3 / 18$ & w & $\begin{array}{l}490 \\
500\end{array}$ & $\begin{array}{l}\mathbf{2 1 8} \\
\mathbf{2 1 8}\end{array}$ & 3,850 & & \\
\hline 18 & $y$ & 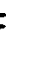 & $\begin{array}{l}35 \mathrm{NH} \\
36 \mathrm{NM}\end{array}$ & $\begin{array}{l}3 / 18 \\
3 / 18\end{array}$ & $\begin{array}{l}580 \\
x\end{array}$ & $\begin{array}{l}490 \\
490\end{array}$ & 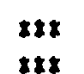 & 3,876 & & \\
\hline \multirow[t]{2}{*}{19} & $n$ & F & 37 LO & $1 / 25$ & 700 & 50 & $x \times x$ & 7,344 & & \\
\hline & $x$ & & 38 LO & $1 / 25$ & ๓ & 490 & xtx & & 22,470 & \\
\hline
\end{tabular}




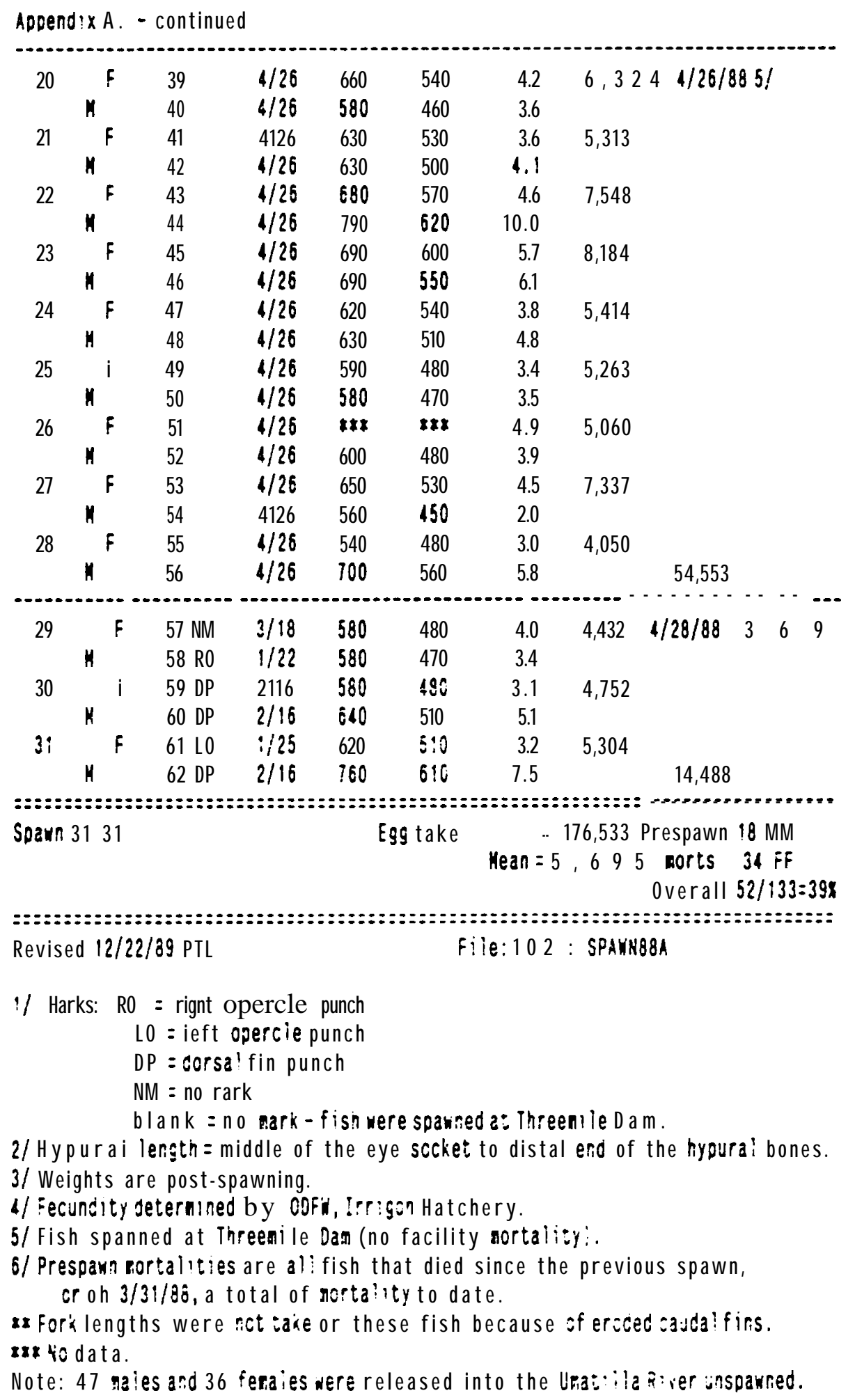


Appendix 9. Date of spaunirg for suamer steinead versus date of collection.

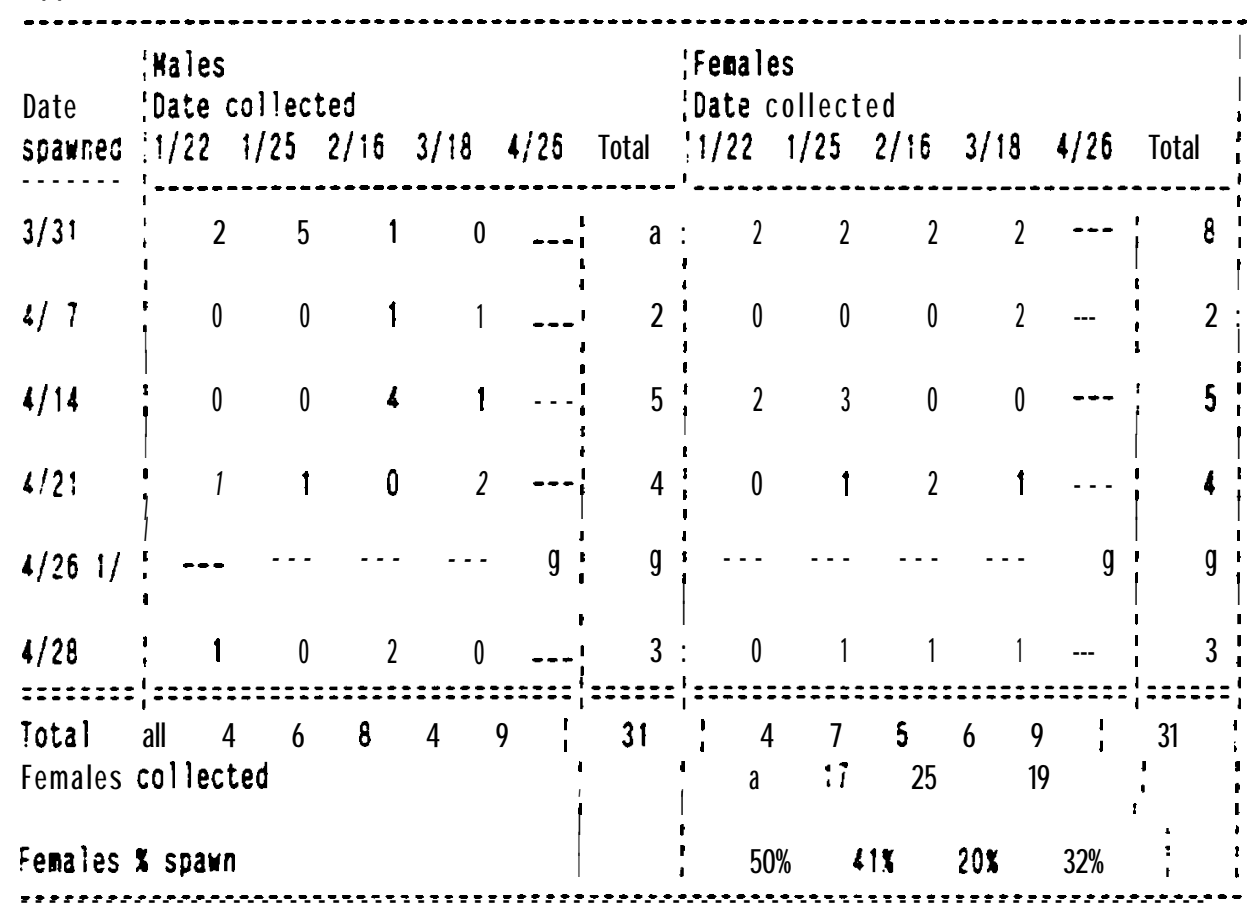

Revised 12/22/89 PTL

Filenane : 102 : corsp88A

1/ Collected and spawned at Threemile Dam on this date: [selected from 17 females and $22 \mathrm{ma} i \mathrm{z}$ unclipped fish that were available). 


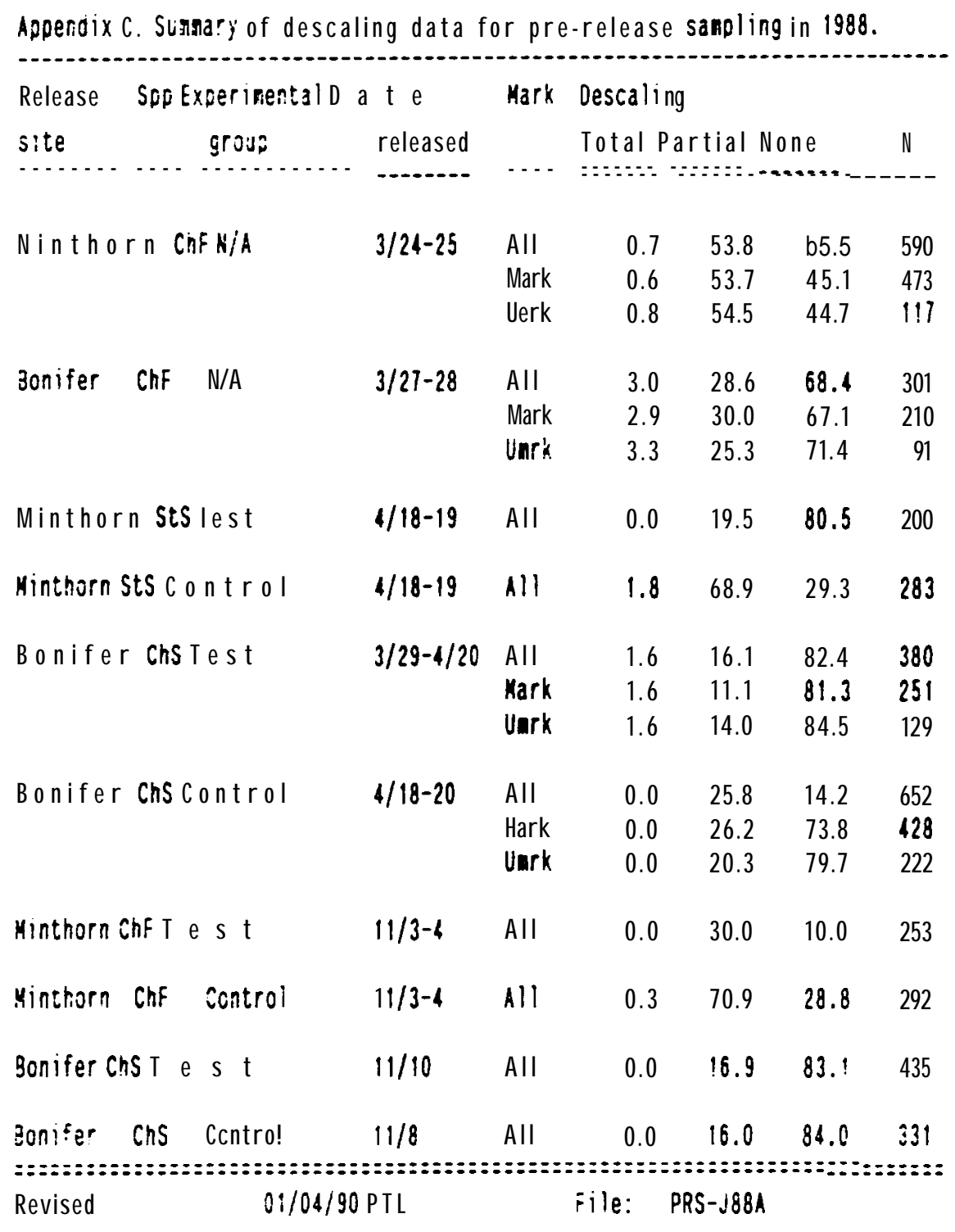



pump intake for 1988 .

RTM Data Summary

MINTHORN INSTALLED 12-22-87

\begin{tabular}{|c|c|c|c|c|}
\hline & & \\
\hline Date & Minimum & Maximum & Mean & Median \\
\hline 1Jan $\operatorname{Ja}$ & 6.2 & 6.7 & 6.5 & 6.4 \\
\hline $2 \operatorname{Jan} 88$ & 5.6 & 6.8 & 6.3 & 6.3 \\
\hline $3 \mathrm{Jan} 88$ & 4.6 & 5.6 & 5.2 & 5.4 \\
\hline $4 \operatorname{Jan} 8 \theta$ & 5.2 & 5.9 & 5.5 & 5.6 \\
\hline $5 \mathrm{Jan} 88$ & 5.4 & 6.7 & 6.0 & 6.1 \\
\hline $6 J \operatorname{Jan} 88$ & 5.8 & 6.8 & 6.3 & 6.4 \\
\hline $7 \mathrm{Jan} 88$ & 5.6 & 6.3 & 6.0 & 6.0 \\
\hline $8 J \sin 88$ & 5.6 & 6.5 & 6.0 & 6.0 \\
\hline $9 \mathrm{Jan} 88$ & 5.7 & 7.0 & 6.4 & 6.5 \\
\hline $10 \operatorname{Jan} \theta 8$ & 7.0 & 7.8 & 7.3 & 7.2 \\
\hline $11 \operatorname{Jan} 88$ & 6.4 & 7.3 & 6.9 & 7.0 \\
\hline $12 \operatorname{Jan} \theta 8$ & 6.7 & 7.8 & 7. 1 & 7.1 \\
\hline $13 \operatorname{Jan} \theta 8$ & 7.1 & 8.1 & 7.6 & 7.7 \\
\hline $14 \operatorname{Jan} \theta \theta$ & 7.9 & 8.8 & 8.3 & 8.5 \\
\hline $15 \mathrm{Jan} 88$ & 4.2 & 8.8 & 8.2 & 8.4 \\
\hline $16 \mathrm{~J} \operatorname{an} \theta \theta$ & 7.5 & 8.7 & 8.0 & 8.0 \\
\hline $17 \operatorname{Jan} \theta \theta$ & 7.1 & a. 4 & 7.6 & 7.6 \\
\hline $18 \mathrm{Jan} 88$ & 6.7 & 7.3 & 7.1 & 7.1 \\
\hline $19 \operatorname{Jan} B 8$ & 6.4 & 8.1 & 7.2 & 7.1 \\
\hline 20Jan 88 & 6.7 & 7.7 & 7.1 & 7.1 \\
\hline $21 \mathrm{Jan} B \mathrm{~B}$ & 6.8 & 8.2 & 7.4 & 7.2 \\
\hline $22 \operatorname{Jan} 88$ & 5.9 & 7.7 & 6.9 & 7.0 \\
\hline $23 \operatorname{Jan} \theta 8$ & 6.9 & 8.2 & 7.4 & 7.3 \\
\hline $24 \operatorname{Jan} 8 \theta$ & 6.0 & 7.4 & 6.8 & 6.9 \\
\hline $25 \operatorname{Jan} 88$ & 6.4 & 8.1 & 7.2 & 7.3 \\
\hline $26 \operatorname{Jan} 88$ & 6.2 & 7.3 & 6.8 & 7.0 \\
\hline $27 \mathrm{Jan} 88$ & 6.6 & 7.9 & 7.3 & 7.4 \\
\hline $28 \operatorname{Jan} B 8$ & 6.9 & 7.8 & 7.4 & 7.4 \\
\hline $29 \mathrm{~J}$ an 88 & 7.5 & 8.6 & 8.1 & 8.2 \\
\hline $30 J a n 88$ & 6.6 & 7.9 & 7.1 & 7.1 \\
\hline $31 \mathrm{~J}$ anB 8 & 5.7 & 7.1 & 6.4 & 6.4 \\
\hline Total January & 4.2 & 8. a & 6.9 & 7.0 \\
\hline
\end{tabular}


Appendix D continued.

RTM Data Summary

MINTHORN INSTALLED 12-22-87

Date

1 FebB日

2FebBB

3Feb8B

4Feb8B

SFeb88

GFebBB

7Feb88

AFebBB

9Feb8B

$10 F e b \theta$

11 Feb 88

1 2FebBB

$13 F e b 8 B$

$14 F e b B B$

$15 F e b 88$

$16 F e b 8 B$

$17 F=b B 8$

$18 F e b 88$

$19 F e b 8 B$

zOFebB日

21Feb88

2EFeb8B

23Fe b88

24Feb88

25Feb88

26Feb8B

27Feb8B

2BFebB日

29Feb88

Tot al February

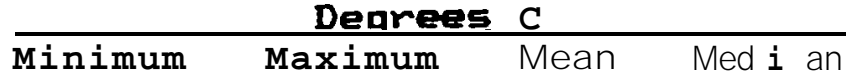

\section{3}

3.7

4. 9

5.6

5.7

6.3

7.2

7.8

8.2

7.4

7.2

6.6

7.1

6.5

6.9

6.2

6.0

6.4

6.2

6.4

6.3

6.0

5.3

5.4

5.6

5.6

6.0

6.4

7.1

3. 7
5. 9

5. 5

7.5

7.2

7. 1

7.8

8. 6

8. 9

8. 7

8. 9

9.1

8. 9

a. 3

8. 2

8. 2

8.1

7.2

8. 7

9.0

9.4

9.4

8. 9

8. 0

8. 5

8. 5

8.7

9.2

9.0

10.0

10.0
5.1

4. 6

6.3

6.5

6.5

7.1

7.9

8. 4

8. 5

8.2

8. 2

8. 0

7. 6

7.4

7.7

7.0

6.7

7.5

7.6

7.8

7.8

7. 3

6.7

6.9

7.0

7.2

7.5

7.8

8. 5

7.3
5.3

4. 7

6.7

6.6

6.5

7.0

8.0

8.4

0. 5

8.2

8.2

8.2

7.7

7.4

7.8

6.9

6.7

7.5

7.6

7.8

7.8

7.3

6.6

6.9

7.1

7.3

7.6

7.9

8.2

7.4 
Appendix D continued.

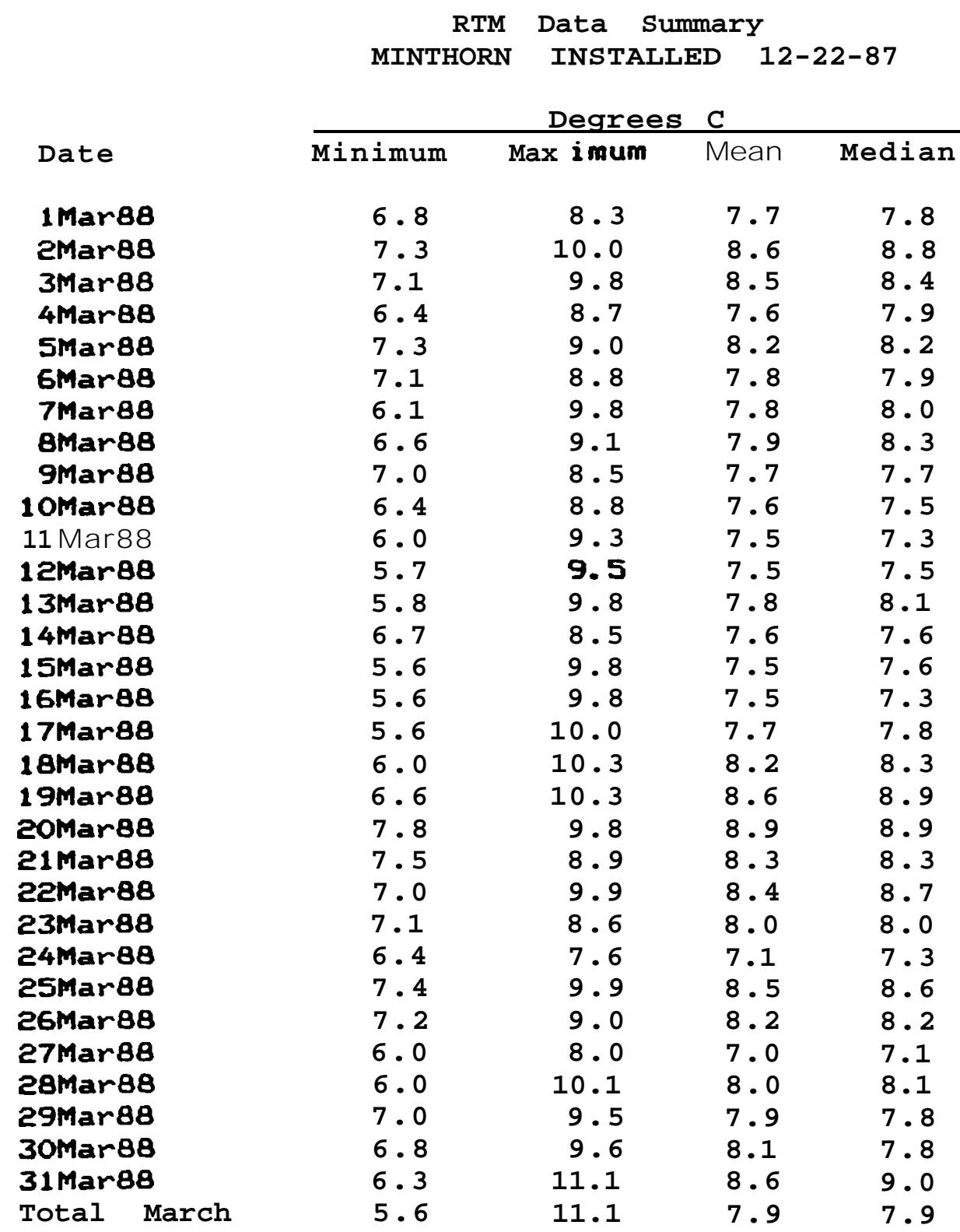


Appendix D continued.

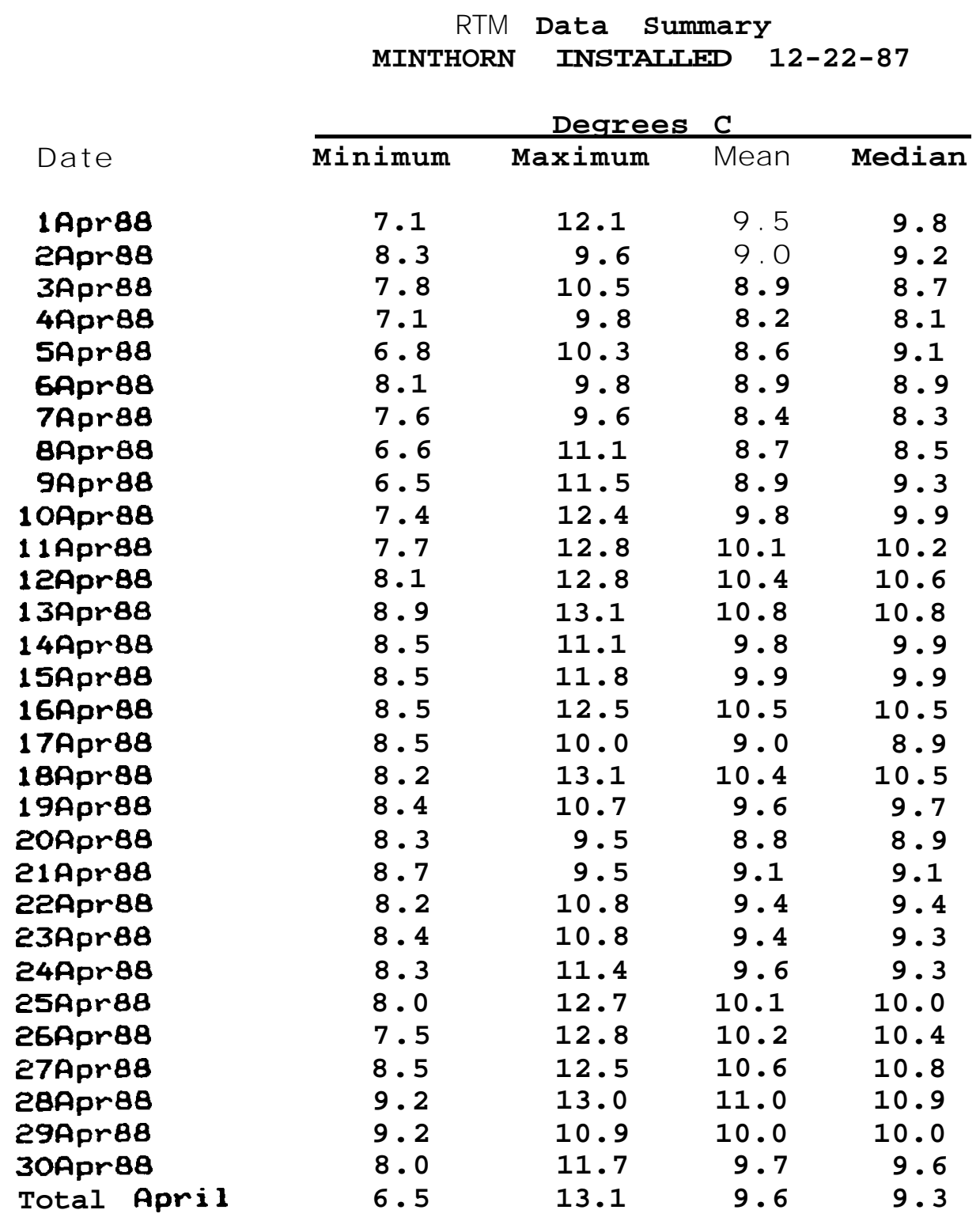


Appendix D continued.

\begin{tabular}{|c|c|c|c|c|}
\hline & & Data & mar & \\
\hline & MINTI & INSTAL & ED & $2-87$ \\
\hline & & Deorees & C & \\
\hline Date & Minimum & Maximum & Mean & Pled ian \\
\hline 1 May 88 & 7.9 & 11.3 & 9.5 & 9.4 \\
\hline 2May 88 & 7.9 & 10.3 & 9.2 & 9.3 \\
\hline 3 May 88 & a. 5 & 12.0 & 10.1 & 10.1 \\
\hline 4 May 88 & a. 2 & 9.7 & 9.1 & 9.3 \\
\hline 5 May 88 & a. 4 & 11.8 & 9.9 & 10.1 \\
\hline 6 Mау 88 & 9.1 & 12.3 & 10.5 & 10.3 \\
\hline 7 May88 & a. 5 & 12.5 & 10.5 & 10.6 \\
\hline 8 May 88 & 9.0 & 12.1 & 10.6 & 10.7 \\
\hline 9 May8 & 9.5 & 14.2 & 11.6 & 11.7 \\
\hline 10 May 88 & 9.8 & 14.4 & 12.1 & 12.0 \\
\hline 11 May 88 & 10.3 & 14.8 & 12.4 & 12.5 \\
\hline 1 2May 88 & 11.1 & 15.2 & 12.8 & 12.7 \\
\hline 13 May 88 & 10.4 & 13.1 & 11.6 & 11.4 \\
\hline 14 May $8 B$ & 9.6 & 13.8 & 11.5 & 11.5 \\
\hline 15 May 88 & 9.7 & 14.7 & 12.1 & 12.3 \\
\hline 16 May 88 & 9.8 & 11.9 & 10.7 & 10.7 \\
\hline 17 May 88 & a. 9 & 12. $a$ & 10.8 & 10.8 \\
\hline 18 May 88 & 9.7 & 13.1 & 11.3 & 11.3 \\
\hline 19 May 88 & 10.0 & 14.6 & 12.1 & 12.0 \\
\hline 20May88 & 10.0 & 14.8 & 12.3 & 12.3 \\
\hline 21 May88 & 10.3 & 15.4 & 12.7 & 13.0 \\
\hline 22May88 & 11.2 & 15.1 & 13.0 & 12.7 \\
\hline 23Mау 88 & 10.7 & 14.8 & 12.6 & 12.4 \\
\hline 24 Maу 88 & 10.7 & 15.2 & 12.8 & 12.7 \\
\hline 25May88 & 10.8 & 15.0 & 12.8 & 12.7 \\
\hline 26Мау 88 & 10.6 & 14.3 & 12.4 & 12.4 \\
\hline 27May88 & 11.2 & 14.5 & 12.8 & 12.7 \\
\hline Ëmay 88 & 10.3 & 12.3 & 11.2 & 11.2 \\
\hline 29Mау 88 & 9.8 & 12.6 & 10.9 & 10.9 \\
\hline 30Мау 88 & 9.8 & 13.9 & 11.7 & 11.7 \\
\hline 31 Мау 88 & 10.8 & 12.3 & 11.5 & 11.5 \\
\hline Total May & 7.9 & 15.4 & 11.5 & 11.3 \\
\hline
\end{tabular}


Appendix D continued.

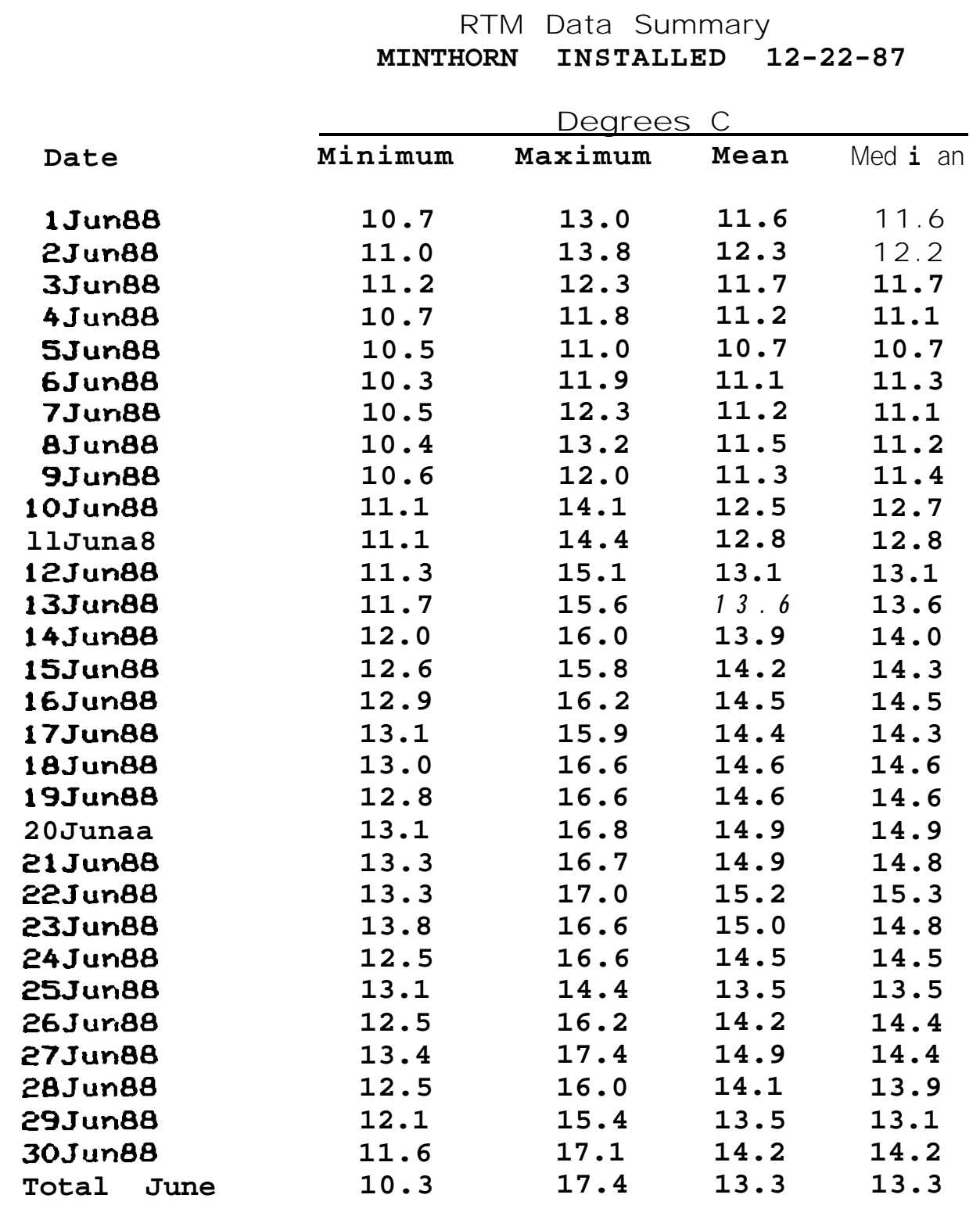


Appendix D continued.

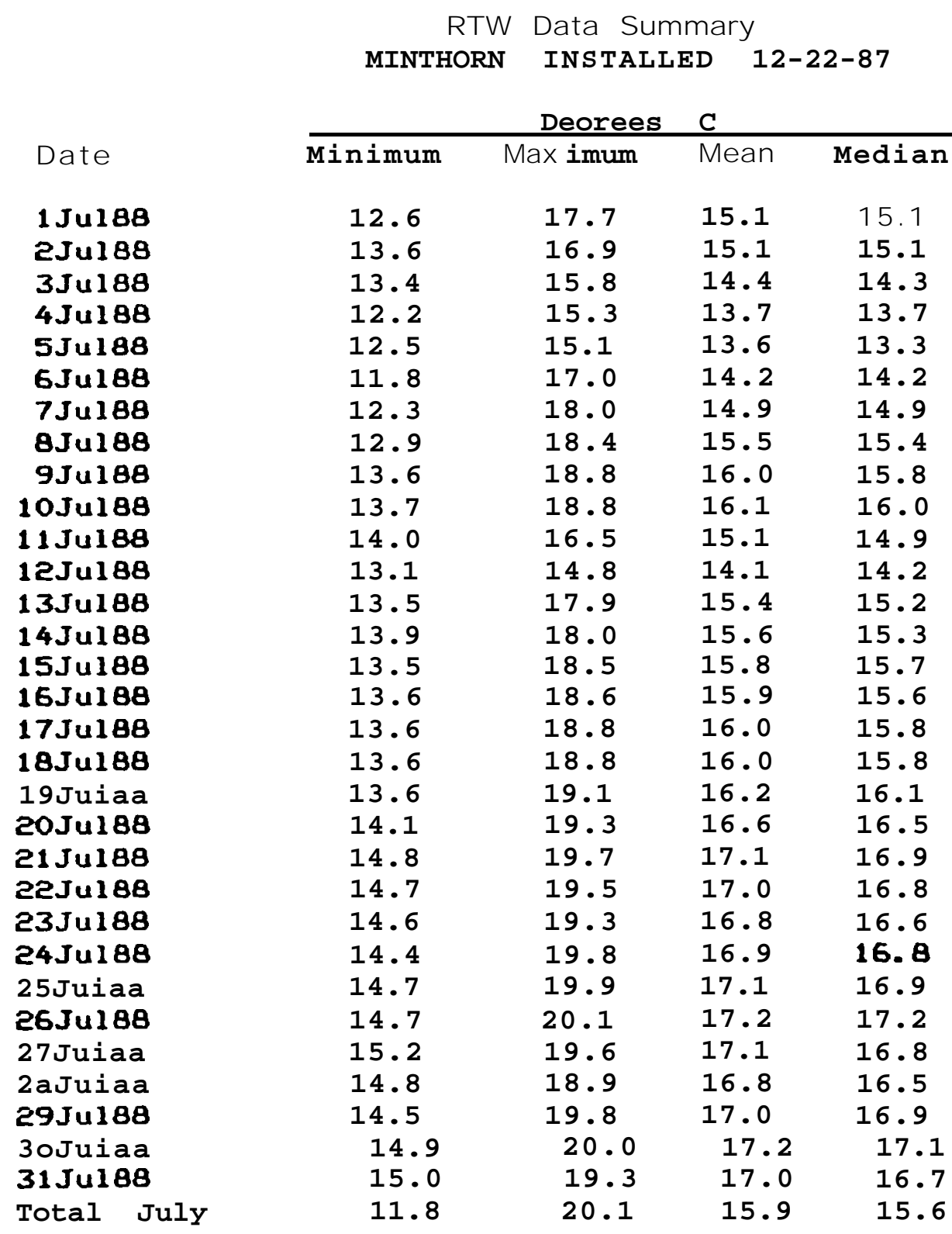




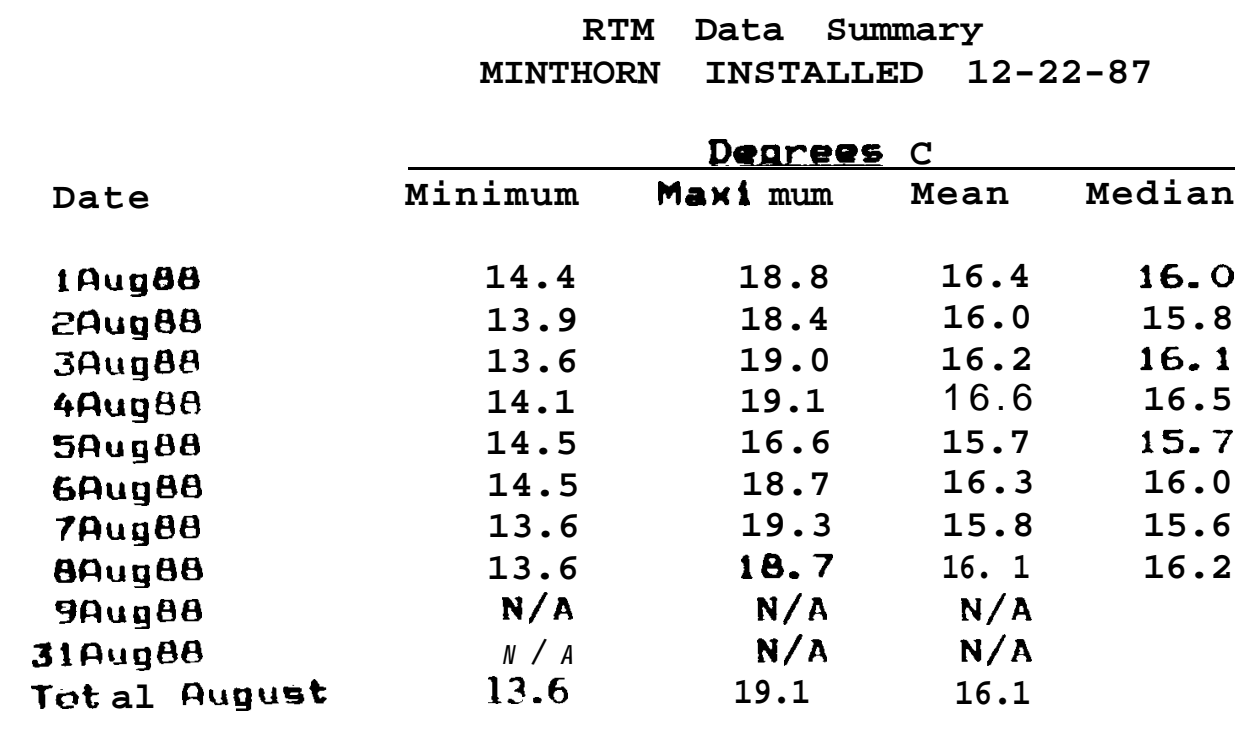

RTM Data Summary

MINTHORN INSTALLED 9/9/88

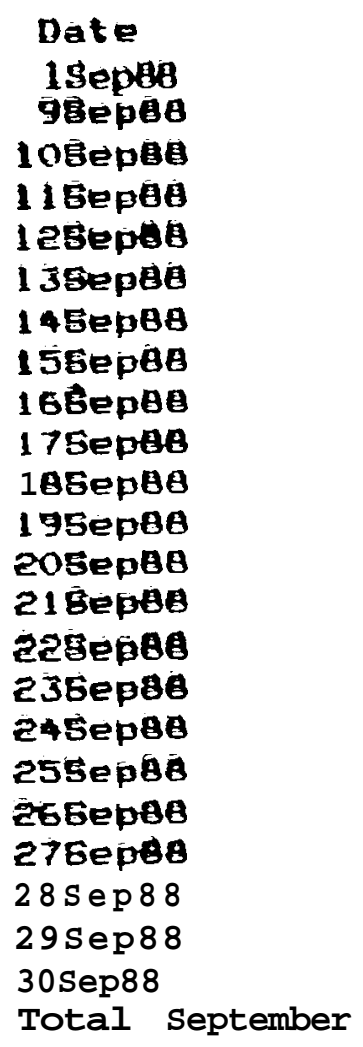

\begin{tabular}{cccc}
\multicolumn{4}{c}{ Deqrees } \\
Minimum & Maximum & Mean & Median \\
N/A & N/A & N/A & \\
N/A & N/A & N/A & \\
13.3 & 15.2 & 14.0 & 14.1 \\
13.0 & 16.4 & 14.4 & 13.9 \\
12.6 & 16.2 & 14.3 & 14.3 \\
12. a & 16.4 & 14.4 & 14.3 \\
13.1 & 16.8 & 15.0 & 14.6 \\
13.3 & 16.5 & 15.2 & 15.3 \\
14.0 & 16.3 & 15.0 & 15.0 \\
13.0 & 14.5 & 13.8 & 13.3 \\
12.6 & 15.7 & 14.0 & 13.6 \\
13.8 & 15.4 & 14.5 & 14.4 \\
13.1 & 14.4 & 13.7 & 13.7 \\
11.9 & $1 \% .9$ & 13.5 & 13.9 \\
12.4 & $1 \% .4$ & 13.9 & 13.9 \\
12.7 & 15.0 & 13.9 & 14.0 \\
13.9 & 16.5 & 15.0 & 14.5 \\
14.1 & 15.3 & 14.7 & 14.9 \\
13.6 & 15.9 & 14.7 & 14.5 \\
14.1 & 15.2 & 14.6 & 14.7 \\
12.4 & 15.3 & 13.8 & 13.7 \\
12.5 & 15.4 & 13.3 & 13.8 \\
12.6 & $1 \% .7$ & 14.1 & 14.0 \\
11.3 & 17.1 & 14.3 & 14.3
\end{tabular}


Appendix D continued.

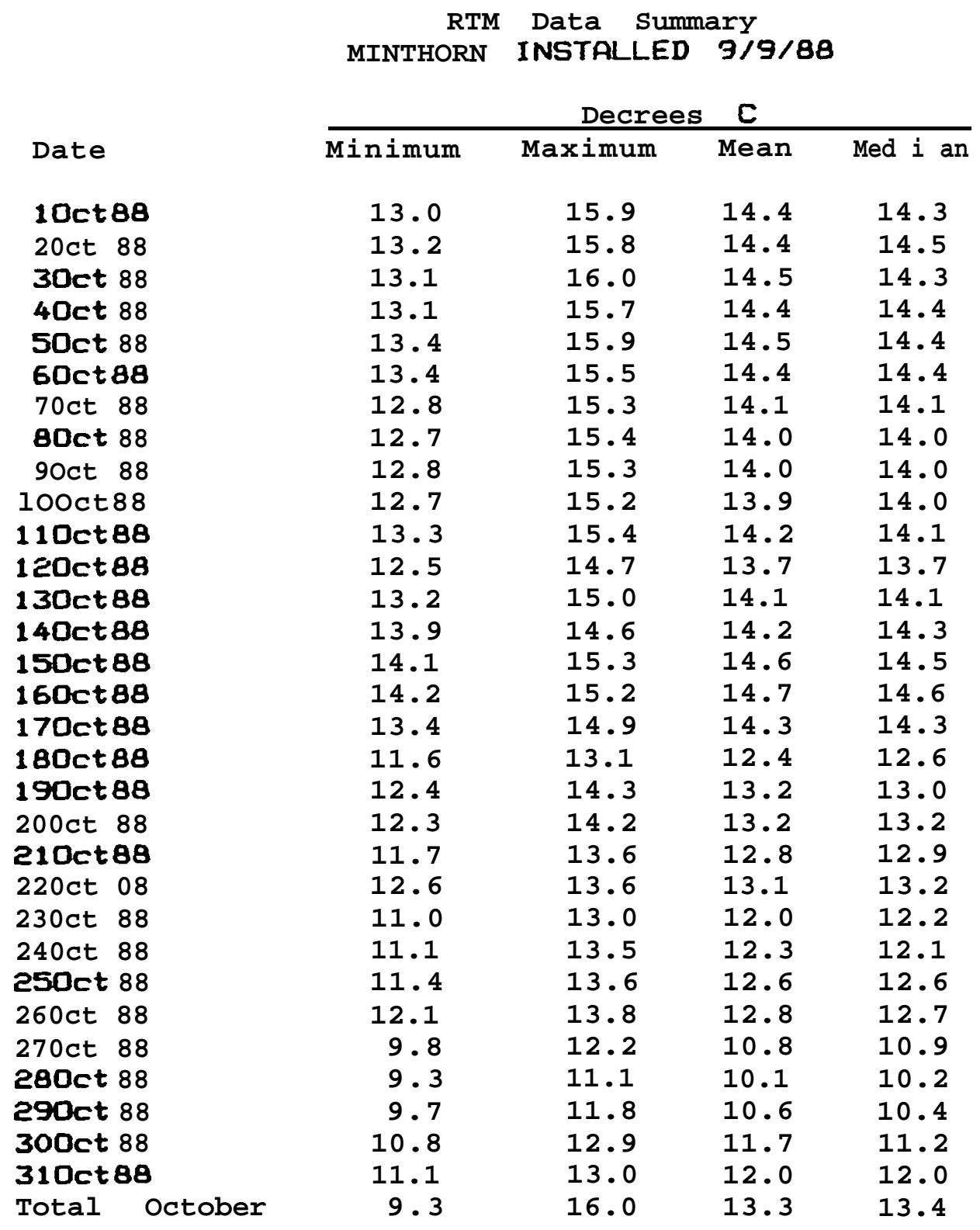


Appendix D continued.

\begin{tabular}{|c|c|c|c|c|}
\hline \multirow[b]{2}{*}{ Date } & \multicolumn{4}{|c|}{$\begin{array}{c}\text { Mata Summary } \\
\text { N INSTALLED } 9 / 9 / 88 \\
\text { Dearees C } \\
\end{array}$} \\
\hline & Minimum & Maximum & Mean & Medi an \\
\hline 1 Nov8B & 11.0 & 12.6 & 11.8 & 11.7 \\
\hline 2Nov88 & 12.1 & 12.6 & 12.4 & 12.4 \\
\hline 3Nov8B & 12. 1 & 12.8 & 12.5 & 12.5 \\
\hline $4 N o v 88$ & 12.1 & 13.2 & 12.5 & 12.5 \\
\hline SNovBB & 12.3 & 12.8 & 12.7 & 12.7 \\
\hline 6Nov88 & 11.1 & 12.7 & 11.9 & 11.8 \\
\hline 7Nov88 & 10.3 & 11.6 & 11.0 & 11.0 \\
\hline BNov88 & 10.5 & 11.7 & 11.1 & 11.1 \\
\hline 9NovB8 & 10.3 & 11.3 & 10.8 & 10.8 \\
\hline 10 Nov 88 & 10.4 & 11.8 & 11.0 & 10.9 \\
\hline 11 Nov88 & 10.5 & 11.8 & 11.1 & 11.1 \\
\hline 12 Nov88 & 10.8 & 11.5 & 11.1 & 11.1 \\
\hline 13 Nov88 & 9.9 & 10.9 & 10.5 & 10.5 \\
\hline 14 Nov88 & 8.8 & 10.5 & 9.7 & 9.9 \\
\hline 15 Nov日8 & 9.8 & 10.8 & 10.3 & 10.1 \\
\hline 16 Nov8B & 10.7 & 11.5 & 10.9 & 10.8 \\
\hline 17 Nav88 & 10.3 & 11.0 & 10.6 & 10.5 \\
\hline 18 Nov 88 & 10.2 & 10.8 & 10.5 & 10.4 \\
\hline 19 Nov88 & 10.0 & 10.9 & 10.4 & 10.3 \\
\hline 2ONOV88 & 10.5 & 11.3 & 10.9 & 10.9 \\
\hline 21 Nav88 & 10.2 & 10.8 & 10.4 & 10.3 \\
\hline $22 N o v 88$ & 10.7 & 11.8 & 11.3 & 11.2 \\
\hline 23Nov88 & 10.4 & 11.6 & 11.1 & 11.1 \\
\hline 24Nov88 & 10.0 & 10.4 & 10.3 & 10.3 \\
\hline 25Nov8B & 10.1 & 10.8 & 10.5 & 10.5 \\
\hline 26Nov88 & 10.0 & 10.7 & 10.3 & 10.3 \\
\hline 27 Nov88 & 9.5 & 10.8 & 10.1 & 9.9 \\
\hline 28Nov88 & 10.3 & 10.9 & 10.6 & 10.5 \\
\hline 29Nov88 & 10.1 & 11.0 & 10.5 & 10.4 \\
\hline 30 Nov 88 & 9.2 & 10.3 & 9.8 & 9.9 \\
\hline Total November & 8. 8 & 13.2 & 10.9 & 10.8 \\
\hline
\end{tabular}


Appendix D continued.

$$
\begin{gathered}
\text { RTM Data Summary } \\
\text { MINTHORN INSTALLED } 9 / 9 / 88
\end{gathered}
$$

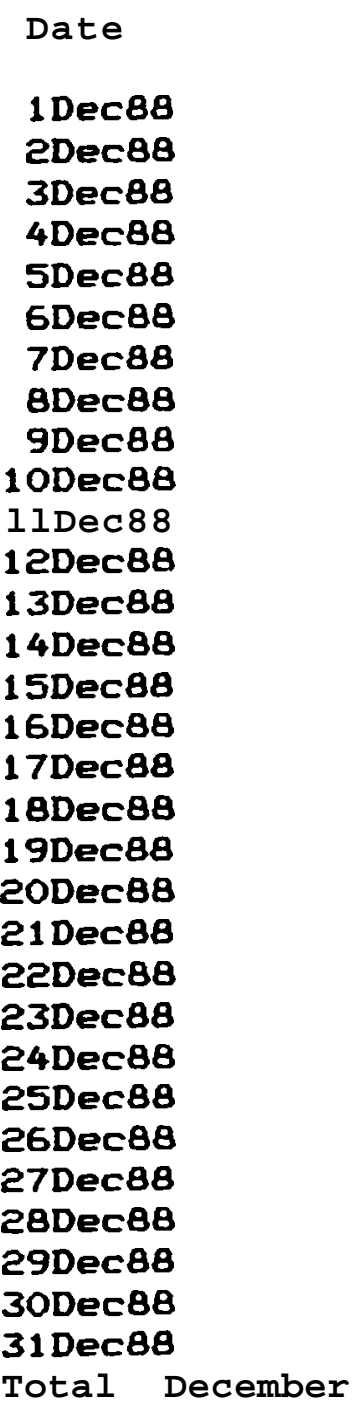

\begin{tabular}{rrrr}
\multicolumn{4}{c}{ Degrees } \\
Minimum & Maximum & Mean & Median \\
9.0 & & & \\
9.1 & 9.8 & 9.5 & 9.4 \\
9.4 & 9.8 & 9.5 & 3.6 \\
9.2 & 9.8 & 9.7 & 9.7 \\
8.8 & 9.6 & 9.4 & 3.3 \\
9.1 & 9.8 & 9.2 & 3.2 \\
10.0 & 10.8 & 9.8 & 9.4 \\
9.6 & 10.8 & 10.3 & 10.3 \\
10.3 & 10.3 & 10.0 & 10.0 \\
10.0 & 10.8 & 10.5 & 10.5 \\
10.1 & 10.7 & 10.3 & 10.4 \\
10.2 & 10.6 & 10.4 & 10.4 \\
9.3 & 11.3 & 10.7 & 10.5 \\
8.8 & 10.8 & 10.2 & 10.1 \\
7.5 & 9.5 & 9.2 & 3.2 \\
7.4 & 8.6 & 8.2 & 8.1 \\
6.9 & 8.4 & 7.8 & 7.8 \\
6.8 & 8.0 & 7.5 & 7.6 \\
7.8 & 7.8 & 7.4 & 7.5 \\
8.5 & 9.1 & 8.5 & 8.8 \\
8.1 & 8.9 & 8.8 & 8.8 \\
8.1 & 8.9 & 8.5 & 8.6 \\
7.9 & 8.6 & 8.4 & 8.5 \\
6.7 & 8.8 & 8.3 & 0.1 \\
6.9 & 8.1 & 7.4 & 7.5 \\
6.1 & 7.8 & 7.5 & 7.5 \\
6.4 & 7.1 & 6.6 & 6.7 \\
6.3 & 7.8 & 7.0 & 6.8 \\
6.4 & 7.1 & 6.6 & 6.7 \\
8.1 & 8.2 & 7.2 & 7.2 \\
8.1 & 8.5 & 8.3 & 8.3 \\
6.1 & 8.8 & 8.3 & 8.3 \\
& 11.3 & 8.7 & 8.8
\end{tabular}


Apperidix E. Dissolved oxygen at Kinthorn

Acclimation Facility in 1988. I/

\begin{tabular}{|c|c|c|c|c|c|c|}
\hline $\begin{array}{l}\text { Rceway } \\
\text { Date }\end{array}$ & Intake & $\begin{array}{l}\text { Lower } \\
\text { Head }\end{array}$ & $\begin{array}{l}\text { Rway } \\
\text { Outlet }\end{array}$ & $\begin{array}{l}\text { Eprer } \\
\text { Head }\end{array}$ & $\begin{array}{l}\text { Rway } \\
\text { Outlet }\end{array}$ & $\begin{array}{l}\text { Mlitary } \\
\text { Tiae }\end{array}$ \\
\hline $3 / 10 \mathrm{Fz}$ & & 10.4 & 9.0 & $: 0.5$ & 8.6 & 0932 \\
\hline $2 ; 11 \mathrm{~F}$ & & 10.0 & & 10.2 & & $09 ! 7$ \\
\hline $3: 12 \mathrm{~F}$ & & & 0.0 & & 9.4 & 0923 \\
\hline $3 / 13 \mathrm{~F}$ & & 9.8 & 7.5 & 10.0 & 8.6 & 0915 \\
\hline $3 / 14 \mathrm{~F}$ & & & 9.0 & & 9.5 & 1117 \\
\hline $\begin{array}{l}3 / 17 \mathrm{~F} \\
3 / 98 \mathrm{~F}\end{array}$ & & $i 3$ & 14 & $: 2.0$ & 14.0 & 0315 \\
\hline $3: 9 F$ & & 11 & g & 12 & 9 & 1023 \\
\hline$F$ & & 13 & 13 & $i \hat{\imath}$ & & 0430 \\
\hline $3120=$ & & 12 & 10 & 12 & 113 & 0838 \\
\hline$=$ & & 12 & 10 & 12 & 19 & 0343 \\
\hline $3 / 21 F$ & & 12 & 11 & 12 & 10 & 0828 \\
\hline 5 & & 12 & 11 & 12 & $10 !$ & 0433 \\
\hline $3122 F$ & & 12 & 12 & 12 & $9:$ & 1258 \\
\hline $3 / 23 F$ & & 12 & 11 & 10 & $11:$ & $091 ?$ \\
\hline $\mathrm{F}$ & & 12 & 11 & 11 & $11 !$ & 0215 \\
\hline $3 / 24 F$ & & 12 & $1:$ & 12 & $11:$ & 0813 \\
\hline $3 / 25 \mathrm{~F}$ & & & & 10 & $10 ?$ & 1039 \\
\hline $3 / 265$ & & 10 & 8 & & & 0723 \\
\hline $3 / 27 \mathrm{~F}$ & & 10 & 9 & & & 0855 \\
\hline $3 / 28 \mathrm{~F}$ & & 1: & 12 & & & 0910 \\
\hline $3 / 29 \mathrm{~F}$ & & 12 & 11 & & & 0953 \\
\hline $\mathrm{F}$ & & i) & 11 & & & 0353 \\
\hline $3 / 30 \mathrm{~F}$ & & 11 & 11 & & & 0955 \\
\hline $3 / 31 F$ & & $: 1$ & $: 0$ & & & 0910 \\
\hline ? & & $: 2$ & $j$ & & & 0212 \\
\hline$\$ / 1 F$ & & $\because:$ & $: c$ & & & 0853 \\
\hline $4: 25$ & & $: 2$ & 11 & & & $09: 9$ \\
\hline$f$ & & 12 & 10 & & & $020 i$ \\
\hline $1 / 3 F$ & & 12 & 11 & & & 0823 \\
\hline$F$ & & $i i$ & 10 & & & 0109 \\
\hline $1 / 45$ & & 11 & $11:$ & & & $101 ?$ \\
\hline $\mathrm{F}$ & & 11 & 10 & & & 0423 \\
\hline $4 / 5 F$ & & 11 & 10 & & & 0938 \\
\hline $4 / 6 \%$ & & 9.8 & 8.8 & & & 0915 \\
\hline $4 / 7 F$ & & 10.3 & 9.0 & & & 1141 \\
\hline $4 / 87$ & & $: 2.4$ & 11.8 & & & $10: 5$ \\
\hline $\mathrm{F}$ & & 12.2 & 10.8 & & & 0106 \\
\hline $6 / 9 F$ & & 9.6 & 8.7 & & & 0842 \\
\hline $4 / 10=$ & & 9.3 & 3.2 & & & 0815 \\
\hline $4 / 11 \mathrm{~F}$ & & 11.8 & 10.6 & & & 1010 \\
\hline $4: 12 \mathrm{~F}$ & & 10.0 & 9.0 & & & $10 ! 7$ \\
\hline $4 / 13 \mathrm{~F}$ & & 10.4 & 9.4 & & & 1025 \\
\hline $4 / 14 \mathrm{~F}$ & & 9.8 & 9.2 & & & 0920 \\
\hline $4 / 15 \mathrm{~F}$ & & 12.4 & 10.8 & & & $08: 9$ \\
\hline$F$ & & $1 \hat{6} .2$ & 13.3 & & & 0246 \\
\hline $1 / 16=$ & & 12.4 & 10.4 & & & $093 i$ \\
\hline$=$ & & il. $\hat{x}$ & 15.4 & & & 0408 \\
\hline $4 ! 17=$ & & 15 & ". & & & 0839 \\
\hline & & $i 2$ & $i:$ & & & 1235 \\
\hline
\end{tabular}

\begin{tabular}{|c|c|c|c|c|c|c|}
\hline $4 / 18 \mathrm{~F}$ & & $\begin{array}{l}12 \\
12\end{array}$ & $\begin{array}{l}11 \\
! 1\end{array}$ & & & $\begin{array}{l}1215 \\
0408\end{array}$ \\
\hline $4 / 19 \mathrm{~F}$ & & 12 & 10 & & & -- \\
\hline $5 / 13$ & 7.9 & & & & & 0815 \\
\hline $5 / 26$ & 9.4 & & & & & 1045 \\
\hline$E / 3$ & 9.8 & & & & & 1200 \\
\hline $6 / 8$ & 9.4 & & & & & $0 ! 15$ \\
\hline $6 / 10$ & 7.8 & & & & & $0 ? 43$ \\
\hline $6 / 16$ & 10.0 & & & & & $: 120$ \\
\hline $6 / 23$ & 10.2 & & & & & $: 2 i 0$ \\
\hline $6 / 30$ & $: 1.0$ & & & & & 0910 \\
\hline $7 / 7$ & 8.6 & & & & & 0929 \\
\hline $7 / 14$ & 8.2 & & & & & $: 010$ \\
\hline $7 / 25$ & 8.8 & & & & & 0330 \\
\hline $7 / 28$ & 5.6 & & & & & 0848 \\
\hline $8 / 4$ & 6.1 & & & & & 0818 \\
\hline 8! 125 & 5.5 & & & & & 1125 \\
\hline $9 / 1$ & 5.0 & & & & & 0130 \\
\hline $9 / 8$ & 7.2 & & & & & 0115 \\
\hline $9 / 15 \mathrm{~F}$ & & 7.5 & 6.8 & 8.3 & 7.4 & $: 018$ \\
\hline $9 / 16 \mathrm{~F}$ & & 7.6 & 5.6 & & & 0844 \\
\hline $9 / 17 \mathrm{~F}$ & & 7.4 & 5.8 & 7.2 & $6 . \hat{3}$ & 0841 \\
\hline $9 / 18 \mathrm{~F}$ & & 8.7 & 6.7 & 8.5 & 7.2 & 2914 \\
\hline $9 / 19 \mathrm{~F}$ & & 8.9 & 1.1 & 8.8 & $i .2$ & $09: 2$ \\
\hline $9 / 20 \mathrm{~F}$ & & 9.0 & 6.8 & 8.8 & 7.4 & $02 ! 5$ \\
\hline $9 / 2 ! F$ & & 9.8 & 3.4 & 8.6 & 7.0 & ก९2? \\
\hline $9 / 225$ & & 14 & ? & if & $\varepsilon$ & 6995 \\
\hline $9 / 23 \mathrm{~F}$ & & 3.0 & 5.6 & 7.3 & 5.4 & $: 934$ \\
\hline $9 / 24 \mathrm{~F}$ & & 7.5 & 5.0 & 7.4 & 6.2 & 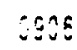 \\
\hline$g / 25 \mathrm{~F}$ & & 5.6 & 4.7 & 1.2 & 4.8 & 6945 \\
\hline $9126 \mathrm{~F}$ & & 9.8 & 8.8 & 7.4 & 0.2 & i\&17 \\
\hline $9 / 27 \bar{F}$ & & & & 10.0 & 8.0 & 8910 \\
\hline$F$ & & 8.0 & 7.4 & & & $0 ? 25$ \\
\hline $9 / 28 F$ & & 10.0 & $i .8$ & 3.0 & 5.4 & 3825 \\
\hline $9 / 29 \mathrm{~F}$ & & j. 1 & 5.8 & 9.4 & 5.3 & 0844 \\
\hline$=130 F$ & & 3.2 & 3.7 & 0.0 & 5.5 & 0839 \\
\hline $10 / 1 \mathrm{~F}$ & & $i .2$ & 8.0 & 3.0 & 5.8 & 0840 \\
\hline $1012 \mathrm{~F}$ & & $i .5$ & 6.4 & 7.4 & 6.2 & 0830 \\
\hline $10 / 3 \mathrm{~F}$ & & 3.1 & $6 .:$ & & 6.2 & $094 ?$ \\
\hline $10 / \& F$ & & 1.0 & 5.0 & $i .1$ & 6.3 & 0830 \\
\hline $1015=$ & & & 5.5 & & 7.4 & 0900 \\
\hline $10 / 65$ & & 8.2 & 7.6 & 8.1 & 8.1 & 1220 \\
\hline $1017=$ & & 1.8 & 7.8 & 8.7 & 7.4 & 0900 \\
\hline $10 / 8=$ & & 1.1 & $i .1$ & 7.7 & 1.2 & 0907 \\
\hline $10 / 10 \mathrm{~F}$ & & 7.9 & 7.6 & 8.6 & 8.0 & 0825 \\
\hline$: 0 / 11 \mathrm{~F}$ & 31 & & & 1.6 & 1.0 & 0922 \\
\hline$F$ & & 8.5 & 8.3 & & & 0245 \\
\hline $10 / 12 \mathrm{~F}$ & & 8.3 & 1.5 & & & 0845 \\
\hline $\bar{F}$ & & & & 8.4 & 8.0 & 1203 \\
\hline $10 / 13 \mathrm{~F}$ & & 8.4 & 7.8 & & & 1342 \\
\hline & & & & 8.4 & 8.1 & 0952 \\
\hline
\end{tabular}


Appendix E. continued.

\begin{tabular}{|c|c|c|c|c|c|c|c|}
\hline \multicolumn{2}{|l|}{$0: 14:$} & & \multicolumn{2}{|c|}{$8.2 \quad ? .6$} & \multicolumn{2}{|l|}{$095 ?$} \\
\hline $10 / 15 \mathrm{~F}$ & & $8 . \varepsilon$ & $8.6:$ & & & 1032 & \\
\hline $10 / 16 F:$ & & 7.8 & & & & 0109 & \\
\hline$F !$ & & 7.2 & & & & 0200 & \\
\hline $10 i 17 \mathrm{~F}:$ & & 6.9 & & & & $1 i 13$ & \\
\hline F ! & & & & $7 . ?$ & $i .3:$ & $! 254$ & \\
\hline F : & & & & 8.2 & & 5235 & \\
\hline $10 / 18 \mathrm{~F}$ & & & & 7.9 & & 3852 & \\
\hline$F:$ & & & & 9.2 & & 1005 & \\
\hline i & & 8.1 & & & & $: 200$ & \\
\hline$F$ & & 8.5 & & & & 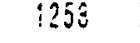 & \\
\hline $10 / 26 \bar{F}$ & & $7 . \hat{8}$ & $6.8 \vdots$ & $7 . \therefore$ & j. .5 & 0330 & \\
\hline $0023=1$ & & 9.6 & $8.8:$ & $9 . i$ & 今. & $30 \bar{i}$ & \\
\hline 活: & & 9.5 & $8.8 !$ & 5.2 & $\therefore \therefore$ & $\therefore E \hat{i}$ & \\
\hline $10 / 25=$ & & 3.1 & $8.2 !$ & 3.4 & $\hat{c}, \dot{t}$ & 0368 & \\
\hline $10: 20=1$ & & 3.2 & $6.8:$ & 8.0 & 3.3 & loil & \\
\hline $10 / 27 F$ & & $\partial . \hat{0}$ & $6.8 \vdots$ & & & $0 \leq 53$ & \\
\hline $10 / 28 F$ & & 8.9 & 1.01 & & & 0908 & \\
\hline $10 / 29 \mathrm{~F}$ & & 1.5 & $6.8 !$ & & & 0848 & \\
\hline $10 / 30 \mathrm{~F}$ & & 1.6 & $1.0 !$ & & & 0817 & \\
\hline $10 / 3 i=$ & & 8.0 & $6.4 i$ & & & 8018 & \\
\hline 11 ! if! & & 8.2 & $6.0 !$ & & & 0725 & \\
\hline $11 / 17$ & 5.8 & & & & & 0827 & \\
\hline $11 / 23$ & 1.0 & & & & & 0708 & \\
\hline $121 ?$ & 8.0 & & & & & 0950 & \\
\hline $12 / 15$ & 7.8 & & & & & --- & \\
\hline $1 \hat{2} ; \hat{2} 2$ & 8.0 & & & & & 0205 & \\
\hline$i 2 i ? 9$ & 8.0 & & & & & $\$ 120$ & \\
\hline \multicolumn{8}{|c|}{ 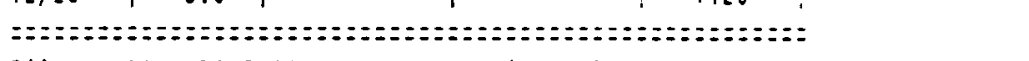 } \\
\hline \multicolumn{4}{|c|}{ File : :02 : COH:Y88n } & evised & PT! & $14-9 a r_{1}-90$ & \\
\hline \multicolumn{8}{|c|}{ 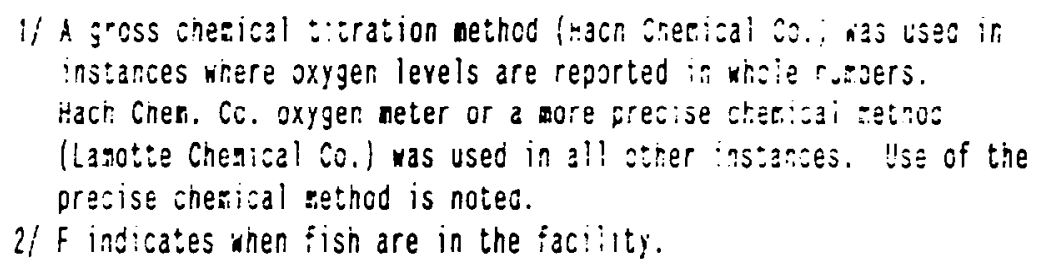 } \\
\hline
\end{tabular}


Appendix F. Electronic thermograph data from Bonifer outlet for 1988 ,

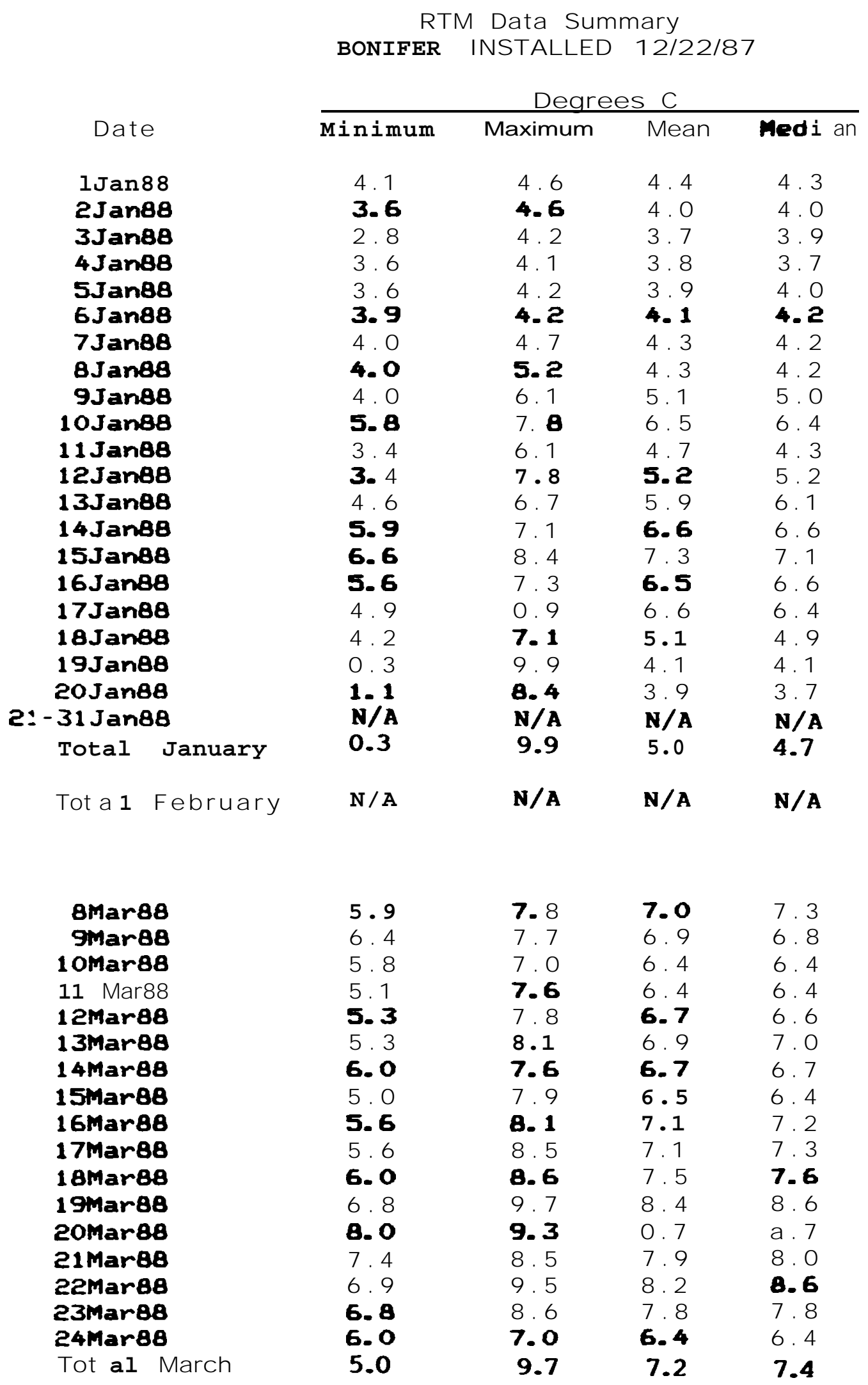


Appendix F continued,

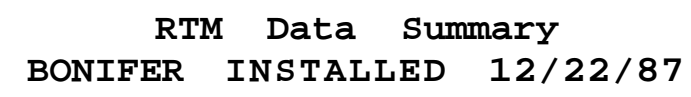

Date

Deqrees

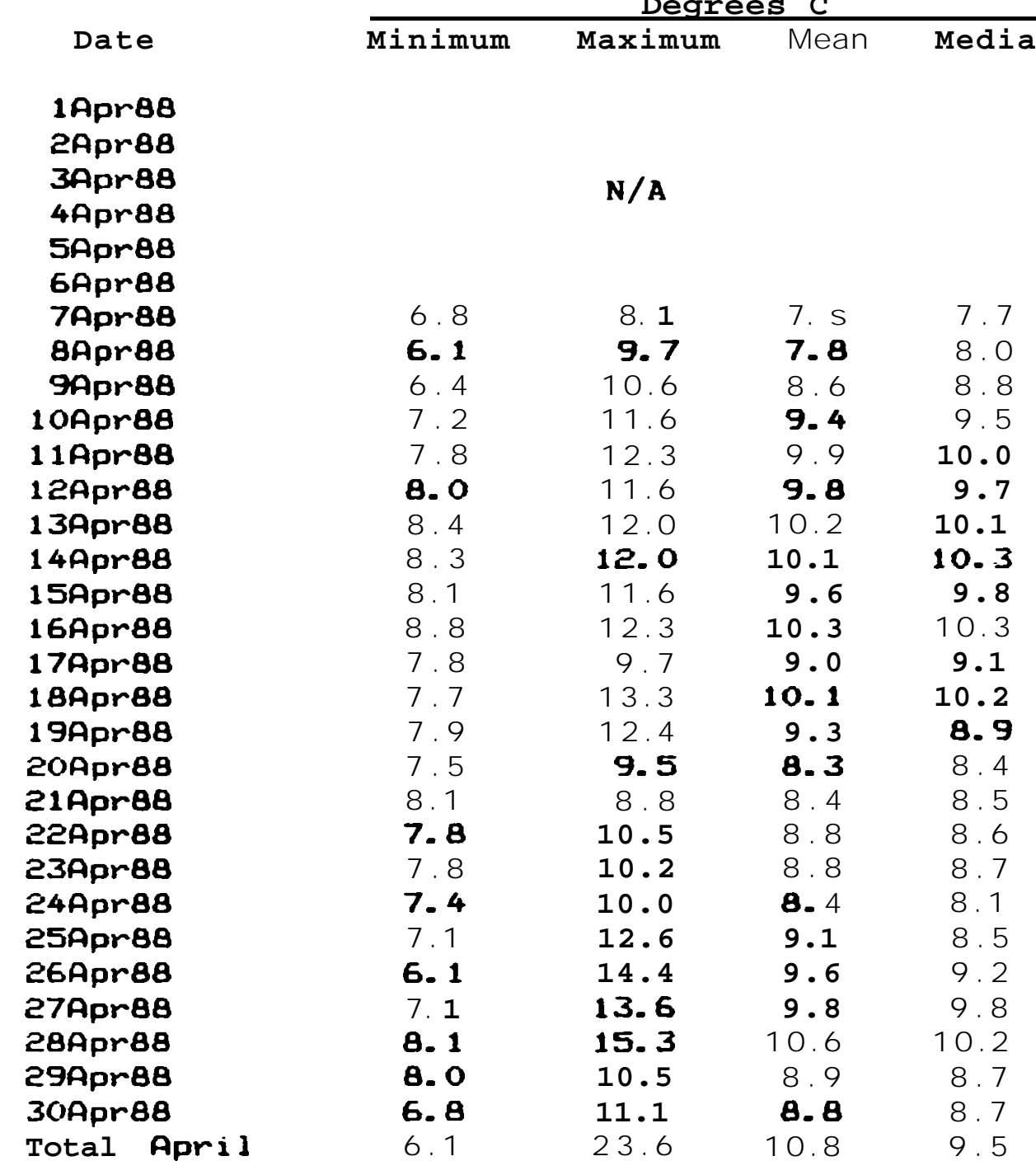


Appendix F continued.

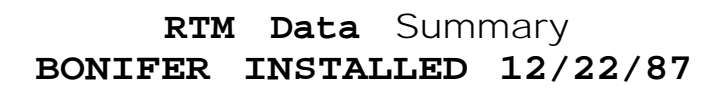

\section{Date}

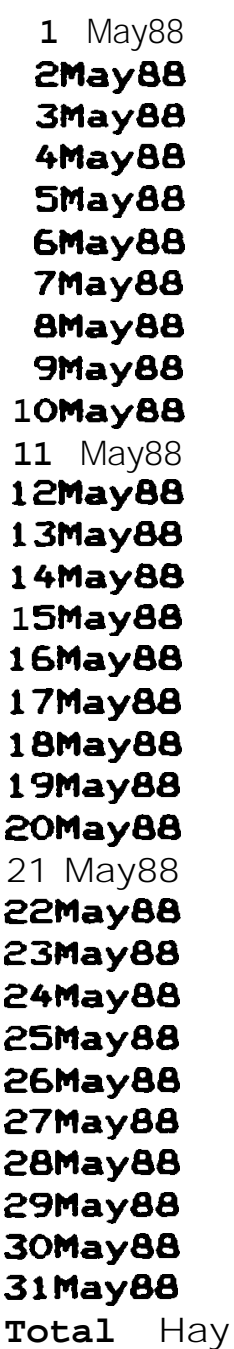

\section{Dearees}

Minimum Maximum Mean Medi an

$\begin{array}{rrrr}6.7 & 11.0 & \mathbf{8 . 5} & 8.1 \\ 6.5 & 10.1 & 8.5 & 8.7 \\ 7.7 & 11.7 & 9.3 & 8.7 \\ 7.1 & 8.6 & 8.0 & 8.1 \\ 7.4 & 11.3 & 9.0 & 9.0 \\ 8.5 & 12.2 & 10.1 & 9.8 \\ 7.7 & 11.7 & 9.7 & 9.9 \\ 8.1 & 12.6 & 10.2 & 9.9 \\ 8.7 & 14.7 & 11.2 & 10.8 \\ 8.7 & 14.2 & 11.3 & 11.3 \\ 9.5 & 14.4 & 11.8 & 11.7 \\ 9.8 & 15.3 & 12.6 & 13.6 \\ 10.0 & 13.9 & 11.5 & 11.0 \\ 9.0 & 12.8 & 10.7 & 10.5 \\ 8.7 & 15.9 & 11.9 & 12.2 \\ 9.5 & 11.3 & 10.3 & 10.3 \\ 8.8 & 13.7 & 10.7 & 10.5 \\ 9.1 & 13.8 & 10.9 & 10.7 \\ 9.5 & 15.0 & 11.8 & 11.6 \\ 9.2 & 15.0 & 12.0 & 11.9 \\ 9.7 & 15.6 & 12.5 & 12.6 \\ 10.5 & 14.9 & 12.7 & 12.6 \\ 10.3 & 15.7 & 12.6 & 12.3 \\ 10.4 & 15.9 & 12.8 & 12.6 \\ 10.5 & 15.9 & 12.9 & 12.7 \\ 10.2 & 15.2 & 12.5 & 12.5 \\ 10.8 & 14.9 & 12.7 & 12.5 \\ 9.9 & 12.0 & 10.9 & 10.8 \\ 9.5 & 12.3 & 10.7 & 10.2 \\ 9.7 & 15.1 & 11.8 & 11.6 \\ 10.0 & 12.7 & 11.1 & 10.9 \\ 6.5 & 15.9 & 11.1 & 10.8\end{array}$


Appendix F continued.

\author{
RTM Data Summary \\ BONIFER INSTALLED $12 / 22 / 87$
}

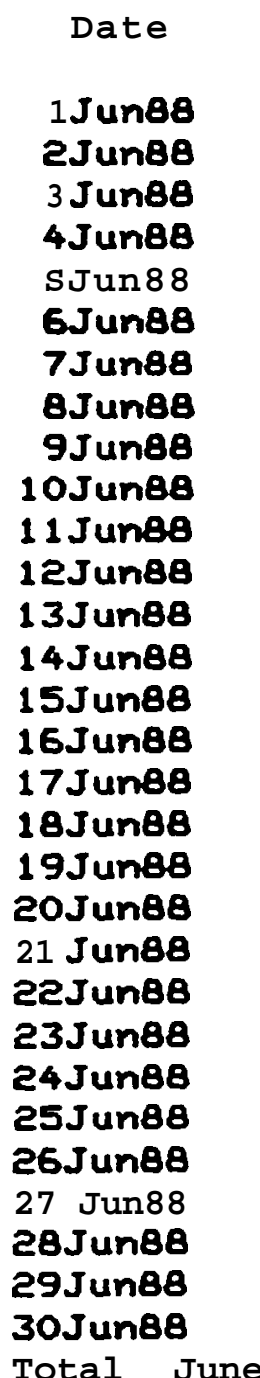

\begin{tabular}{|c|c|c|c|}
\hline \multicolumn{4}{|c|}{ Dearees C } \\
\hline Minimum & Maximum & Mean & Med $i$ an \\
\hline 9.9 & 12.0 & 10.8 & 10.8 \\
\hline 9.9 & 15.4 & 12.3 & 12.6 \\
\hline 10.3 & 12.1 & 11.2 & 11.1 \\
\hline 10.1 & 11.4 & 10.6 & 10.6 \\
\hline 9.8 & 10.2 & 10.0 & 9.9 \\
\hline 9.7 & 12.0 & 10.7 & 10.7 \\
\hline 9.9 & 12.4 & 10.9 & 10.9 \\
\hline 9.8 & 12.1 & 10.7 & 10.4 \\
\hline 9.8 & 11.6 & 10. 7 & 10.8 \\
\hline 10.2 & 14.6 & 12.1 & 12.0 \\
\hline 10.1 & 15.6 & 12.6 & 12.5 \\
\hline 10.2 & 16.6 & 13.0 & 12.8 \\
\hline 10.4 & 16.2 & 13.2 & 13.3 \\
\hline 11.0 & 16.5 & 13.6 & 13.6 \\
\hline 11.6 & 15.9 & 13.7 & 13.7 \\
\hline 12.0 & 17.0 & 14.1 & 14.1 \\
\hline 12.2 & 16.2 & 14.1 & 13.9 \\
\hline 12.0 & 17.8 & 14.6 & 14.6 \\
\hline 11.9 & 17.4 & 14.6 & 14.6 \\
\hline 12.5 & 17.9 & 15.0 & 15.2 \\
\hline 12.6 & 17.4 & 14.8 & 14.6 \\
\hline 12.6 & 18.0 & 15.2 & 15.3 \\
\hline 13.2 & 18.7 & 15.5 & 15.3 \\
\hline 12.3 & 17.4 & 14.8 & 14.7 \\
\hline 12.3 & 14. s & 13.0 & 12.8 \\
\hline 11.8 & 16.4 & 13.9 & 14.1 \\
\hline 12.9 & 17.6 & 15.1 & 14.9 \\
\hline 12.7 & 17.4 & 14.9 & 14.8 \\
\hline 12.6 & 15.4 & 13.9 & 13.9 \\
\hline 11.6 & 16.8 & 14.1 & 13.9 \\
\hline 9.7 & 18.7 & 13.1 & 12.9 \\
\hline
\end{tabular}


Appendix F continued.

RTM Data Summary

BONIFER INSTALLED 12/22/87

Date

1 JulB8

2Ju188

$3 J u 188$

$4 \mathrm{JU} 18 \mathrm{~B}$

$5 J u 188$

$6 J u 188$

$7 J u 188$

$8 J u 188$

$9 J u 188$

$10 \mathrm{Ju} 188$

$11 \mathrm{Ju} 188$

$12 J u 18 B$

$13 J u 188$

$14 J u 18 B$

$15 J u 188$

$16 J u 188$

$17 J u 188$

$18 J u 188$

$19 J u 188$

20Ju18B

$21 \mathrm{Ju} 188$

22Ju188

23Ju188

$24 J u 188$

25Ju18

26Ju188

27Ju18B

2BJu188

29Ju188

$30 J u 188$

$31 \mathrm{Ju} 188$

Total July
Dearees

Minimum Maximum Mean Nedian

12.6

17.7

1s. 1

15.1

13.4

13.5

12.1

12.6

12. 0

13.0

13.6

14.1

14.3

14.3

13.4

13.1

14.0

14.1

14.5

14.6

14. $\mathrm{s}$

14.7

15.0

15.4

15. $\mathrm{s}$

15.4

15.0

15.5

15.5

15.5

14.7

13.5

14.2

14.3

12.0 $\begin{array}{lll}15.9 & 14.7 & 14.8\end{array}$

15. $2 \quad 13.6 \quad 13.5$

$\begin{array}{lll}15.3 & 13.8 & 13.5\end{array}$

17. $\mathrm{s} \quad 14.7 \quad 14.8$

$17.6 \quad 15.3 \quad 15.2$

$18.0 \quad 15.8 \quad 15.0$

$18.6 \quad 16.2 \quad 16.1$

$19.0 \quad 16.6 \quad 16 . \mathrm{S}$

18. $116.3 \quad 16.3$

$15.7 \quad 14.1 \quad 14.1$

$18.0 \quad 15.3 \quad 15 . \mathrm{s}$

$17.4 \quad 15.7 \quad 15.5$

$18.6 \quad 16.2 \quad 16.0$

$18.4 \quad 16.4 \quad 16.3$

$18.3 \quad 16.4 \quad 16.5$

$17.8 \quad 16.2 \quad 16.1$

$18.0 \quad 16.3 \quad 16.2$

$18.3 \quad 16.6 \quad 16.4$

$18.8 \quad 16.9 \quad 16.7$

$19.7 \quad 17.3 \quad 17.0$

$18.5 \quad 16.9 \quad 17.0$

$18.1 \quad 16.5 \quad 16.5$

18. 5 16.9 16.8

18. $3 \quad 16.9 \quad 16.6$

$19.0 \quad 17.0 \quad 16.0$

$17.4 \quad 16.0 \quad 16.2$

$17.2 \quad 15.4 \quad 15.5$

$17.3 \quad 15.8 \quad 15.9$

$17.3 \quad 15.8 \quad 15.9$

$19.7 \quad 15.9 \quad 15.9$
18.9 $15.6 \quad 15.3$ 
Appendix F continued.

RTM Data Summary

BONIFER TNSTAIIED 12/22/87

Date

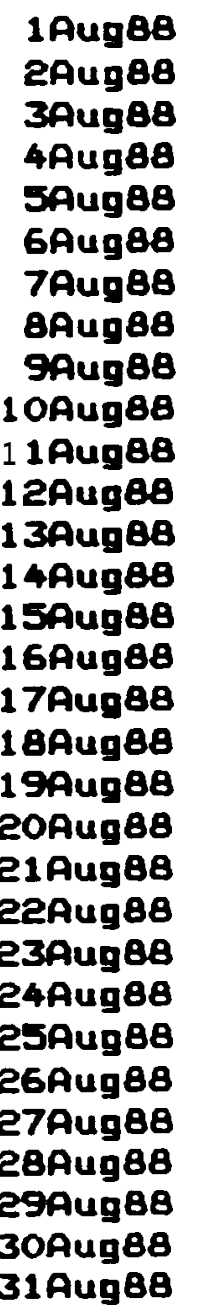

Total August

$\frac{\text { Dearees } c}{\text { Minimum Maximum Mean Median }}$

13.6

17.8

15.6

15.5

11.7

16.9

14.2

14.3

11.9

17.0

14.4

14.2

12.1

23.4

16.1

14.3

11.0

18.2

14.0

13.6

11.3

22.0

15. 3

13.0

10.1

22.0

14.6

12.9

22.6

15.0

15.7

15.7

15.8

16.1

15.2

15.7

15.4

15.3

15.1

14.9

14.8

14.6

14.9

14.6

14.7

15. 5

15.6

15.3

15.2

15.6

15.5

14.8

14.8

15.2

13.4

14.1

14.0

14.3

14.5

13.8

14.0

13.4

13.8

13.3

12.9

13.4

12.8

16.2

14.3

13.9

14.3

13.9

13.5

13.7

13.8

14.0

12.9

15.7

14.1 
Appendix F continued,

$$
\begin{aligned}
& \text { RTM Data Summary } \\
& \text { BONIFER INSTALLED } 12 / 22 / 87
\end{aligned}
$$

\begin{tabular}{ccccc} 
& \multicolumn{4}{c}{ Dearees $\mathbf{C}$} \\
\cline { 2 - 5 } Date & Minimum & Maximum & Mean & Med $\mathbf{i}$ an \\
1Sep88 & 12.3 & 18.8 & 14.9 & 14.8 \\
2Sep88 & 12.7 & 18.8 & 15.1 & 14.9 \\
35ep88 & 13.3 & 17.0 & 14.9 & 15.0 \\
4Sep88 & 13.5 & 16.5 & 15.0 & 15.1 \\
5Sep88 & 13.5 & 15.8 & 14.8 & 15.0 \\
6Sep8B & 13.1 & 18.3 & 15.5 & 15.3 \\
7Sep88 & 13.9 & 18.0 & 15.5 & 15.1 \\
8Sep88 & 12.1 & 16.5 & 13.9 & 14.0 \\
95ep8B & $\mathbf{N} / \mathbf{A}$ & $\mathbf{N} / \mathbf{A}$ & $\mathbf{N} / \mathbf{A}$ & $\mathbf{N} / \mathbf{A}$ \\
Tot a 1 September & $\mathbf{1 2 . 1}$ & $\mathbf{1 8 . 8}$ & $\mathbf{1 5 . 0}$ & $\mathbf{1 4 . 7}$
\end{tabular}


Appendix F continued.

Date

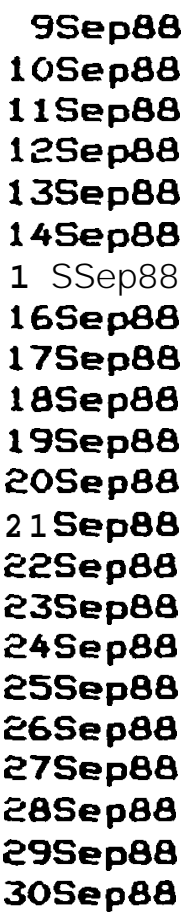

$305 e p 8 \theta$
RTM Data Summary

BONIFER INSTALLED 9/9/8

\section{Denrees $C$}

Minimum Maximum Mean Medi an

11.8

11.0

11.3

10.9

13.4

14.3

14.3

12.8

11.8

13.2

12.6

11.7

12.4

12.9

13.2

14.6

13.9

14.1

12.8

13.1

13.6

10.9
14.3

15.2

15.8

15.9

16.6

16.8

16.2

15.1

14.4

14.0

13.6

14.6

15.0

14.1

16.3

15.5

15.6

15.3

15.1

15.0

16.7

27.9
12.6

12.5

12.9

13.4

15.1

15.7

15.3

13.6

12.9

13.6

13.1

13.0

13.7

13.5

14.5

15.0

14.7

14.7

13.9

14.1

14.9

14.0
12.3

11.6

12.8

12.9

15.0

15. 9

15.4

13.4

12.6

13.6

13.1

12.6

13.6

13.6

13.8

15.0

14.6

14.7

13.8

14.1

14.4

13.9 
Appendix F continued.

\begin{tabular}{|c|c|c|c|c|}
\hline \multirow{2}{*}{ Date } & \\
\hline & Minimum & Maximum & Mean & Median \\
\hline $10 \operatorname{ct} 8 \theta$ & 14.1 & 16.5 & 15.2 & 15.3 \\
\hline 20ct $8 \theta$ & 14.4 & 16.9 & 15.5 & 15.4 \\
\hline $30 c t 88$ & 14.5 & 16.9 & 15.7 & 15.7 \\
\hline $40 c t 88$ & 14.4 & 16.5 & 15.5 & 15.6 \\
\hline 50ct 88 & 14.1 & 16.2 & 15.2 & 15.3 \\
\hline 60 ct 88 & 14. 1 & 15.9 & 15.0 & 15.2 \\
\hline $70 c t 8 \theta$ & 14.0 & 15.3 & 14.8 & 14.9 \\
\hline $80 c t 88$ & 13.9 & 15.9 & 14.8 & 14.7 \\
\hline $90 c t 88$ & 13.8 & 15.7 & 14.7 & 14.8 \\
\hline $100 c t 88$ & 13.6 & 15.9 & 14.7 & 14.7 \\
\hline $110 c t 88$ & 13.4 & 15.1 & 14.2 & 14.4 \\
\hline $120 c t 8 \theta$ & 13.1 & 15.0 & 14.0 & 14.0 \\
\hline $130 c t 88$ & 13.5 & 15.0 & 14.3 & 14.2 \\
\hline $140 c t 88$ & 14.0 & 14.7 & 14.3 & 14.3 \\
\hline $150 c t 88$ & 13.9 & 14.9 & 14.4 & 14.3 \\
\hline $160 c t 88$ & 14.3 & 15.6 & 14.9 & 14.8 \\
\hline $170 c t 88$ & 14.4 & 15.3 & 14.9 & 15.0 \\
\hline $180 c t 88$ & 12.7 & 14.3 & 13.3 & 13.1 \\
\hline $190 c t 88$ & 12.6 & 13.5 & 12.9 & 12.8 \\
\hline $200 c t 88$ & 12.3 & 13.8 & 13.1 & 13.1 \\
\hline $210 \operatorname{ct} 8 \theta$ & 12.3 & 13.8 & 13.1 & 13.4 \\
\hline $220 c t 88$ & 12.8 & 13.9 & 13.4 & 13.5 \\
\hline $230 c t 88$ & 11.7 & 13.0 & 12.4 & 12.4 \\
\hline $240 \operatorname{ct} 88$ & 11.2 & 12.8 & 12.0 & 12.0 \\
\hline $250 c t 88$ & 11.6 & 13.0 & 12.3 & 12.3 \\
\hline $260 c t 88$ & 11.8 & 13.4 & 12.5 & 12.4 \\
\hline $270 c t 88$ & 10.5 & 12.1 & 11.2 & 11.3 \\
\hline $280 c t B 8$ & 9.2 & 10.4 & 9.6 & 9.6 \\
\hline $290 \operatorname{ct} 8 \theta$ & 8.5 & 9.9 & 9.2 & 9.1 \\
\hline $300 c t 88$ & 9.4 & 11.4 & 10.4 & 10.1 \\
\hline $310 \operatorname{ct} 88$ & 10.2 & 12.0 & 11.1 & 11.1 \\
\hline Total October & 8.5 & 16.9 & 13.5 & 13.9 \\
\hline
\end{tabular}


Appendix F continued.

\section{RTM Data Summary BONIFER INSTALLED $9 / 9 / 88$}

\section{Date \\ 1 Nov88 \\ ENov88 \\ 3 Nav 88 \\ $4 N$ Tiv8B \\ $5 N$ Civ8B \\ 6Nov88 \\ 7 Nav88 \\ BNovBB \\ FNo.v88 to \\ 30 Nav $8 B$}

lot a 1 November

Tat a 1 December

\begin{tabular}{ll} 
Deqrees $C$ \\
\hline Minimum Maximum Mean Medi an
\end{tabular}

10.5

11.2

10.9

11.0

11.4

10.8

10.0

10.2

$N / A$

$N / A$

$N / A$

10.0

11.8

11.6

11.8

12.1

12. 1

11.8

11.0

10.2

N/A

$N / A$

N/A

12. 1

11. 2

11.4

11.4

11.5

11.7

11.2

10.4

10.2

$N / A$

$N / A$

$N / A$

11.3

11.3

11.4

11.4

11.4

11.6

11.1

10.4

10.2

$N / A$

$N / A$

N/A

11.3

N/A 
Appendix G. Dissolved oxygen and teaperature at Bonifer Acclimation Facility in 1988.

\begin{tabular}{|c|c|c|c|c|c|c|c|c|c|c|c|c|c|}
\hline \multirow{3}{*}{ DATE } & \multicolumn{5}{|c|}{ OISSOLVED OXYGEN (ag/1) /1 } & \multicolumn{6}{|c|}{ ':TEMPERATURE (degrees Celcius) } & \multirow{2}{*}{\multicolumn{2}{|c|}{$\begin{array}{l}: \\
\vdots \\
\text { Titime }\end{array}$}} \\
\hline & & MIDPOND & SPRING & SPRING & SPRING & ¿'OUTLET & MIOPOHD & & & & & & \\
\hline & & & 11 & 12 & 13 & $\because 3$ & & 11 & 12 & 13 & $\begin{array}{l}\dddot{1} \\
\because\end{array}$ & & 'i \\
\hline $3 / 10 \mathrm{~F} 2$ & 8.0 & & & & & $\because !$ & & 8 & 6 & & $7 \because$ & & \\
\hline $3 / 11 \mathrm{~F}$ & 1.8 & & & & & $\because$ & & 8 & 5 & & $6 \because 3$ & 1030 & \\
\hline $3 / 12 \mathrm{~F}$ & 1.6 & & & & & $\because 3$ & & 11 & 6 & & $7 \because 3$ & 1258 & \\
\hline $3 / 13 \mathrm{~F}$ & 8.1 & & & & & $\because \because$ & & 11 & 6 & & $7 \because !$ & 1220 & \\
\hline $3 / 11 \mathrm{~F}$ & 1.8 & & & & & $\because \because$ & & 1 & 6 & & $7 \dddot{11}$ & 1310 & \\
\hline $3 / 15 \mathrm{~F}$ & & & & & & 31 & & 8 & 1 & & 711 & 1145 & \\
\hline $3 / 16 \mathrm{~F}$ & & & & & & 11 & & 8 & 6 & & 611 & 1108 & \\
\hline $3 / 17 \mathrm{~F}$ & & & & & & $\because !$ & & 6 & 6 & & $\because !$ & 1010 & \\
\hline $3 / 18 \mathrm{~F}$ & & & 1 & & & $\because 3$ & & 6 & 1 & & $7 \because 1$ & 945 & \\
\hline $3 / 19 \mathrm{~F}$ & & & 1 & & & $\because:$ & & 7 & 6 & & 713 & 1023 & \\
\hline $3 / 20 \mathrm{~F}$ & & & 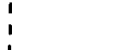 & & & "i. & & 1 & 6 & & $\begin{array}{ll}7 & 11 \\
11\end{array}$ & 1125 & \\
\hline $3 / 21 \mathrm{~F}$ & & & ! & & & $\because 3$ & & 6 & 6 & & 6 6 & 943 & \\
\hline $3 / 22 \mathrm{~F}$ & & & ! & & & "'! & & 9 & 6 & & $\begin{array}{ll}6 & 11 \\
11\end{array}$ & 1053 & \\
\hline $3 / 23 \mathrm{~F}$ & & & ! & & & ?! & & 7 & 6 & & 6 :!' & 1023 & \\
\hline $3 / 24 \mathrm{~F}$ & & & !' & & & II! & & 8 & 6 & & 6 ? & 1058 & \\
\hline $3 / 26 \mathrm{~F}$ & 1 & & $i$ & & & $\because i$ & & 8 & 6 & & 711 & 0810 & \\
\hline $3 / 27 \mathrm{~F}$ & 9 & & & & & 31 & & 8 & 6 & & 6 i! & 1102 & \\
\hline $3 / 28 \mathrm{~F}$ & 11 & & 8 & 9 & 12 & $\because i$ & & 9 & 1 & & $\begin{array}{l}5 \\
5\end{array}$ & 1055 & \\
\hline $3 / 29 \mathrm{~F}$ & 12 & & 13 & 11 & 12 & $\because \vdots$ & & 1 & 1 & & 6 : & 1255 & \\
\hline $3 / 30 \mathrm{~F}$ & 11 & & 13 & 11 & 12 & ?! & & 8 & 1 & & 6 & 1207 & \\
\hline $3 / 31 \mathrm{~F}$ & 12 & & 14 & 11 & 12 & ?i! & & 9 & 1 & & $6 !$ & 1145 & \\
\hline $4 / 1 \mathrm{~F}$ & 12 & & 10 & 12 & 12 & 1 & & 9 & 8 & & 7 : & 1143 & \\
\hline $4 / 2 F$ & 12 & & 12 & 11 & 12 & 1 & & 9 & 8 & & 13 & 1125 & \\
\hline $1 / 36$ & 12 & $i$ & 12 & 12 & 12 & 7 & & 8 & 1 & & $\begin{array}{ll}6 \\
6 \\
11\end{array}$ & 1450 & \\
\hline $111 \mathrm{~F}$ & 12 & & 12 & 10 & 12 & 1 & & 10 & 7 & & $\begin{array}{l}7 \\
711\end{array}$ & 1237 & \\
\hline $1 / 5 \mathrm{~F}$ & & & & & & 7 & & 10 & 8 & & 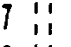 & 1115 & \\
\hline $4 / 6 \mathrm{~F}$ & $11.2:$ & & & & & 9 & & 13 & 7 & & $8 \dddot{1}$ & 1229 & \\
\hline $1 / 7 \mathrm{~F}$ & $9.2:$ & : & & & & 9 & & 10 & 7 & & $8 \dddot{11}$ & 1313 & \\
\hline $1 / 8 \mathrm{~F}$ & $9.4:$ & ' & & & & 1 & & 9 & 7 & & $8 \dddot{11}$ & 1145 & \\
\hline $419 F$ & 8.7 & & 11.0 & 8.6 & 9.5 & 8 & & 9 & 1 & & 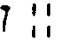 & 1025 & \\
\hline $4 / 10 \mathrm{~F}$ & $10.2:$ & & 11.8 & 9.3 & 10.1 & 8 & & 10 & 8 & & 83 & 1033 & \\
\hline $4 / 11 \mathrm{~F}$ & & & & & & 1 & & 10 & 9 & & $7 \because 3$ & 1113 & \\
\hline $4 / 12 \mathrm{~F}$ & 9.6 & & 8.7 & 8.7 & 8.7 & 10 & & 16 & 8 & & $9 \dddot{i}$ & 1327 & \\
\hline $4 / 14 \mathrm{~F}$ & $9.4 \vdots$ & & 12.0 & 9.0 & 10.9 & $\$ 1$ & & 15 & 8 & & 9 ! & 1433 & \\
\hline $4 / 15 \mathrm{~F}$ & $12.0:$ & & 10.0 & 10.3 & 13.2 & 7 & & 11 & 9 & & 83 & 1233 & \\
\hline $1 / 16 \mathrm{~F}$ & $12.1:$ & & 9.8 & 10.3 & 12.5 & 8 & & 11 & 9 & & 8 "i & 1125 & \\
\hline $4 / 17 \mathrm{~F}$ & $12 !$ & 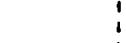 & 12 & 11 & 12 & 7 & & 8 & 8 & & $7 \%$ & 0935 & \\
\hline $4 / 18 \mathrm{~F}$ & $12 !$ & & 10 & 10 & $22.4:$ & 8 & & 10 & 3 & & $7: 1$ & 0955 & \\
\hline $5 / 13$ & $9 !$ & 1 & 10 & 8 & $8.4 !$ & 13 & $i$ & 11 & 11 & 10 & 0 & 0905 & \\
\hline $5 / 20$ & $10 !$ & & 0 & & & 14 & & & & & $\vdots$ & 0935 & \\
\hline $5 / 28$ & 10 & 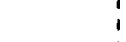 & 11 & 11 & $9.4:$ & 14 & & & & & $\begin{array}{l}31 \\
11\end{array}$ & 0945 & \\
\hline $6 / 3$ & i & 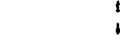 & 10 & 9 & $8.8 !$ & 12 & & 11 & 10 & 10 & 0 & 1033 & \\
\hline $6 / 8$ & $9 !$ & $\vdots$ & 10 & 8 & $8.8:$ & 12 & i & 11 & 10 & 10 & 0 & 1428 & \\
\hline $6 / 10$ & $10:$ & 1 & 9 & 9 & $9.7 !$ & 11 & ! & 12 & 11 & 10 & 0 & 0916 & \\
\hline $6 / 16$ & 10 & ' & 10 & 9 & $9.8:$ & 14 & i & 12 & 12 & 15 & 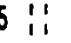 & 1020 & \\
\hline $6 / 23$ & $11:$ & i & 13 & 12 & 111 & 12 & ! & 13 & 12 & 12 & 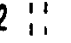 & 1005 & \\
\hline $6 / 30$ & $19:$ & & 11 & 11 & $10.1:$ & !' & & & & & ?! & 1053 & \\
\hline $7 / 7$ & $9 !$ & 1 & 9 & 6 & $8.2:$ & 15 & 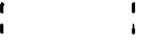 & 13 & 13 & 12 & $2 \%$ & 1023 & \\
\hline $1 / 14$ & $9.0 !$ & ' & 8.8 & 10.6 & $8.6 !$ & 16 & ! & 14 & 16 & 13 & $3 \because \because$ & 1157 & \\
\hline $7 / 19$ & $9.6 !$ & & 10.8 & 10.4 & $11.4:$ & $\begin{array}{l}31 \\
11\end{array}$ & & & & & : & 1015 & \\
\hline
\end{tabular}


Appendix $G$ continued.

\begin{tabular}{|c|c|c|c|c|c|c|c|c|c|c|c|}
\hline $9 / 15 \mathrm{~F}$ & $1.0:$ & & 10.0 & 6.0 & $9.4: 11$ & 13 & & 11 & 16 & $15: 1$ & 1228 :" \\
\hline $9 / 17 \mathrm{~F}$ & 4.9 & 5.8 & 8.2 & 1.4 & $8 \dddot{1}$ & 13 & & 12 & 14 & 13 & 1029 \\
\hline $9 / 18 \mathrm{~F}$ & 6.8 & $8.0:$ & 8.5 & 4.3 & $8.5 \because 1$ & 13 & & 12 & 15 & $16: 11$ & $1213:$. \\
\hline $9 / 19 F$ & 7.0 & $7.4:$ & 8.6 & 6.0 & $8.8 \dddot{1 !}$ & 15 & $16:$ & 14 & 15 & $15:$ & 1152 הi \\
\hline $9 / 20 \mathrm{~F}$ & 7.8 & $6.2:$ & 7.8 & 5.0 & $8.6 !$ & 14 & 14 & 11 & 14 & $16:$ & 1050 \\
\hline $9 / 21 \mathrm{~F}$ & 1.4 & 6.8 & 7.2 & 5.0 & $8.8: 1$ & 13 & 13 & 13 & 14 & $13 ! !$ & $1010: i$ \\
\hline $9 / 22 \mathrm{~F}$ & 10.0 & $8.0 !$ & 6.0 & 8.0 & $11:$ & 15 & 10 & 14 & 14 & $13: 1$ & 1118 :": \\
\hline $9 / 23 \mathrm{~F}$ & 3.8 & 6.6 & 8.8 & 4.3 & $8.7 \dddot{11}$ & 14 & 15 & 12 & 14 & $14: \%$ & $1055: 3$ \\
\hline $9 / 24 F$ & 4.4 & $7.0:$ & 6.6 & 4.6 & $8.5 \mathrm{i!}$ & 15 & 16 & 14 & 15 & $15: !$ & 1117 :" \\
\hline $9 / 25 \mathrm{~F}$ & 4.2 & $7.3 \vdots$ & 8.0 & 6.6 & $7.1 \mathrm{H}$ & 15 & 15 & 12 & 15 & $16: 3$ & 1044 \\
\hline $9 / 26 \mathrm{~F}$ & & 7.8 & 8.8 & 4.5 & $8.4 \dddot{11}$ & 13 & 14 & 14 & 16 & $15 \because !$ & 1115 :". \\
\hline $9 / 27 \mathrm{~F}$ & 6.6 & 7.6 & 6.0 & 6.0 & $11:$ & 15 & 14 & 15 & 13 & $14: \vdots$ & 1030 ï \\
\hline $9128 \mathrm{~F}$ & 6.0 & 5.8 & 6.0 & 8.0 & $8.4 \mathrm{i}$ & 16 & 14 & 14 & 14 & $15:$ & 1025 \\
\hline $9123 F$ & 6.0 & 6.4 & 6.0 & 6.4 & $8: 11$ & 15 & 14 & 14 & 15 & $14 ! 11$ & 1035 :" \\
\hline $9 / 30 \mathrm{~F}$ & 5.2 & 8.0 & 8.5 & 1.6 & 9 ! & 14 & 15 & 14 & 15 & $15 ?$ & 1259 ii \\
\hline $10 / 1 F$ & 4.8 & 5.5 & 1.3 & 4.0 & $7.6 \%$ & 14 & 14 & 13 & 15 & $15: 1$ & 1203 \\
\hline $10 / 2 F$ & 3.8 & 4.0 & 1.2 & 4.3 & $1.3:$ & 15 & 14 & 11 & 16 & $14: 13$ & 0947 \#̈ \\
\hline $10 / 3 F$ & 3.6 & $\cdots$ & 1.6 & 4.0 & $7.5: 3$ & 14 & & 12 & 14 & $14: 1$ & 1047 it \\
\hline $10 / 4 F$ & 4.0 & $6.0 !$ & 1.4 & 4.2 & $1.8: 1$ & 14 & 14 & 13 & 14 & $13 \dddot{1}$ & $1145:$ \\
\hline $10 / 5 \mathrm{~F}$ & 8 & 8 & 10 & 7 & 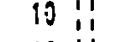 & 17 & 17 & 18 & 16 & $16 ! 1$ & $1105:$ \\
\hline $19 / 8 \mathrm{~F}$ & 1 & 71 & 6 & 8 & $\begin{array}{ll}10 & \text { !1 } \\
1\end{array}$ & & 17 & 18 & 17 & $14 ! !$ & 1132 \\
\hline $10 / 7 \mathrm{~F}$ & 8 & $5 !$ & 5 & 6 & 8 !i & 14 & & & & $\begin{array}{l}u \\
i i\end{array}$ & $1943: 11$ \\
\hline $10 / 8 \mathrm{~F}$ & 6.8 & 7.8 & 7.8 & 5.8 & $1.8: "$ & 14 & & & & :! & 1125 \\
\hline $10 / 9 F$ & 6.5 & $5.3:$ & 1.8 & 7.4 & $8.2: 3$ & & & & & $\because \vdots$ & 1111 :" \\
\hline $10 / 10 \mathrm{~F}$ & 8.0 & 8.0 & 6 & 1 & $8 \mathrm{l}$ & & & & & $\because 1$ & 1100 \\
\hline $10 / 11 \mathrm{~F}$ & 6 & 8.0 & 6 & 1 & 8 ?: & & & & & 萿 & $1124: !$ \\
\hline $10 / 12 \mathrm{~F}$ & 6.8 & 8.0 & 7.4 & 5.4 & $7.1 \dddot{11}$ & & & & & 苚 & $1123: !$ \\
\hline $10 / 13 \mathrm{~F}$ & 6.7 & 8.2 & 7.6 & 5.8 & $7.3: 4$ & & & & & 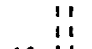 & 1025 \\
\hline $10 / 14 \mathrm{~F}$ & 8 & 6 & 1 & 1 & 8 & $13 !$ & 13 & 13 & 13 & $12 \mathrm{M}$ & $1007: 3$ \\
\hline $10 / 18 \mathrm{~F}$ & 8.0 & & 1.0 & 8.8 & $7 \mathrm{Z}$ & 14 & & 13 & 15 & $13: 11$ & 1233 \\
\hline $10 / 19 \mathrm{~F}$ & 5.0 & & 6.1 & 6.1 & $7.1 \mathrm{M}$ & & & & & ai & 1123 \\
\hline $10 / 20 \mathrm{~F}$ & 5.9 & & 6.7 & 3.9 & $7.2 \dddot{11}$ & 14 & 14 & 14 & 14 & $14 \dddot{11}$ & $1402: i$ \\
\hline $19 / 21 \mathrm{~F}$ & 6.6 & & 6.5 & 3.7 & $7.8: 1$ & 15 & & 14 & 15 & $15: 1$ & 1331 \\
\hline $10 / 22 \mathrm{~F}$ & 6.8 & $1.0:$ & 6.0 & 1.1 & $7.8 \%$ & & & & & :i: & 1349 \\
\hline $10 / 23 \mathrm{~F}$ & 6.4 & 6.6 & 1.3 & 4.2 & $1.3: 11$ & & & & & I:! & $1423: 11$ \\
\hline $10 / 24 F$ & 6.2 & 6.6 & 1.2 & 1.4 & $1 \dddot{1}$ & & & & & 落 & 1252 \\
\hline $10 / 25 \beta$ & $6.2 !$ & & 6.0 & 1.0 & $1.2 \dddot{11}$ & 14 & & 13 & 14 & $14 \quad 11$ & 1020 \\
\hline $10 / 28 F$ & 6.13 & & 6.2 & 1.4 & $7.1: 1$ & 15 & & 15 & 14 & $14: 1$ & $1128:$ \\
\hline $10 / 27 \mathrm{~F}$ & $6.1 !$ & & 1.0 & 4.6 & 1.2 & 13 & & 15 & 14 & 15 : & $1205 \mathrm{I!}$ \\
\hline $10 / 28 \mathrm{~F}$ & $7.2 !$ & & 7.0 & 1.8 & 7.8 & 12 & & 14 & 13 & 14 & 1333 \\
\hline $13 / 29 F$ & $1.6 !$ & $1.2:$ & 1.0 & 4.0 & $7.8 \mathrm{i}$ & 9 & $i 1$ & 13 & 14 & $12: 11$ & 1122 \\
\hline $10 / 31 \mathrm{~F}$ & 1.21 & & 1.0 & 4.2 & $3.4 \dddot{11}$ & 10 & & 14 & 14 & $13: 11$ & 1122 \\
\hline $11 / 1 \mathrm{f}$ & 6.21 & & 6.8 & 4.0 & 1.511 & 12 & & 13 & 16 & 16 :i, & 1150 \\
\hline 1i/ IF & -- & & 7.0 & 4.6 & 1.8 & & & 15 & 14 & $15 \%$ & 0848 \\
\hline $11 / 3 \mathrm{~F}$ & 6.4: & & 1.0 & 4.4 & 7.4 & $12 !$ & & 14 & 14 & is & $1023: 1$ \\
\hline $11 / 4 \mathrm{~F}$ & $8.4 !$ & & 1.0 & 4.1 & 7.8 & $i 2$ & & 14 & 13 & $14 \pi$ & $1040:$ \\
\hline $11 / 5 \mathrm{~F}$ & 1.8 & $7.0:$ & 4.6 & 4.3 & $6.1: 1$ & 12 & 12 & 12 & 14 & $14 \because:$ & $1122:$ \\
\hline $11 / 1 \mathrm{~F}$ & 5.5 & $5.4:$ & 7.4 & 4.8 & $6.9: 1$ & 11 & 11 & 11 & 14 & $13 \dddot{1}$ & 1122 \\
\hline $11 / 7 \mathrm{~F}$ & $4.0:$ & & 7.4 & 4.4 & $0.8 \mathrm{i}$ & 10 & & 12 & 14 & $11:$ & 1123 \\
\hline $11 / 8 \mathrm{~F}$ & $4.0 !$ & & 7.2 & 4.6 & $0.6:$ & 12 & & 12 & 14 & 12 & 1025 \\
\hline $11 / 17$ & $6.0 \vdots$ & & 8.4 & 5.5 & 6.1311 & 11 & & 8 & 13 & 12 & 0921 \\
\hline $11 / 23$ & 5.8 & & 1.8 & 5.6 & $\varepsilon$ & 11 & & 23 & 11 & 1111 & 0748 \\
\hline $12 / 1$ & 1 & & 8 & 8 & $10 \because$ & 13 & & 12 & 14 & 1311 & 1103 \\
\hline 1217 & $8 !$ & & 7 & 8 & $10 \because$ & 13 & & 13 & 14 & $13: 11$ & 0853 \\
\hline $12 / 15$ & 8.0 & 6.8 & 7.8 & 1.2 & 8.2 & & & & & 3 & $\cdots$ \\
\hline $12 / 22$ & $8.0:$ & & 1.0 & 7.4 & $8.4 \because 11$ & & & & & II! & 1218 \\
\hline $12 / 29$ & $8.0:$ & & 7.8 & 1.4 & 8.6 i. & & & & & & 0938 \\
\hline
\end{tabular}

fevised $01 / 35 / 90 \mathrm{Pil}$

Filenane: 102: D0BON88

1/ A gross chenical titration aethod was used when exysen concentrations

are reportes in mole nunbers. in all other instances an

cxygen seter or a nora precise titration rethod was used.

2/ An $f$ indicates tra: $f$ : sh were teing a:elinated in the facility. 
Appendix $\sharp$. Estinated aurber and daily rate of juvenile salnonids captured at Mestland jurenile salnonid trap in 1988. 1/

\begin{tabular}{|c|c|c|c|c|c|c|c|}
\hline \multirow[b]{2}{*}{ Date } & \multicolumn{4}{|c|}{ Saaples-................... } & \multicolumn{3}{|c|}{ Daily rates-........ } \\
\hline & Steelhead & $\begin{array}{l}\text { Chinook } \\
\text { salnoa }\end{array}$ & $\begin{array}{l}\text { Non-sanp } \\
\text { fish }\end{array}$ & $\begin{array}{l}\text { led } \\
\text { Dajs 2/ }\end{array}$ & Steelhead & $\begin{array}{l}\text { Chinoor } \\
\text { saleon }\end{array}$ & $\begin{array}{l}\text { Perceat } \\
\text { sanpled } / 3\end{array}$ \\
\hline & & & & 1 & 18 & 899 & 6 \\
\hline 3726 & 1 & 100 & $\begin{array}{l}801 \\
626\end{array}$ & 1 & $\begin{array}{l}10 \\
41\end{array}$ & 708 & 14 \\
\hline $3 / 28$ & 2 & 102 & 1034 & 1 & 22 & 1116 & 9 \\
\hline $3 / 29$ & 14 & 62 & 68 & 1 & $?$ & 29 & 53 \\
\hline $1 / 1$ & 13 & 126 & 0 & 3 & 4 & 12 & 100 \\
\hline $4 / 4$ & 1 & 16 & 120 & 2 & 31 & 205 & 11 \\
\hline $4 / 6$ & 5 & 143 & 19 & 2 & 4 & 109 & 66 \\
\hline $1 / 8$ & 9 & 65 & 0 & 1 & 9 & 65 & 100 \\
\hline $4 / 9$ & 15 & 32 & 191 & 2 & 29 & 62 & 26 \\
\hline $4 / 11$ & 0 & 60 & 685 & 2 & 0 & 313 & 8 \\
\hline $4 / 13$ & 0 & 79 & 1180 & 3 & 0 & 120 & 6 \\
\hline $4 / 16$ & 2 & 115 & 618 & 2 & 6 & 361 & 16 \\
\hline $4 / 18$ & 0 & 14 & 1936 & 3 & 0 & 670 & 4 \\
\hline $4 / 21$ & 12 & 114 & 900 & 2 & 19 & 164 & 12 \\
\hline $1 / 23$ & 11 & 25 & 0 & 2 & 6 & 13 & 100 \\
\hline $4 / 25$ & 2 & 1 & 0 & 3 & 1 & 0 & 100 \\
\hline $1 / 28$ & 3 & 50 & 0 & 1 & 3 & 50 & 100 \\
\hline $1 / 29$ & 0 & 20 & 0 & 3 & 0 & 9 & 100 \\
\hline $5 / 1$ & 1 & 0 & 0 & 1 & 0 & 0 & 100 \\
\hline $5 / 5$ & 21 & 85 & 0 & 2 & 12 & 43 & 100 \\
\hline $5 / 7$ & 9 & 101 & 290 & 3 & 11 & 122 & 28 \\
\hline $5 / 11$ & 5 & 28 & 150 & 1 & 28 & 155 & 18 \\
\hline $5 / 12$ & 28 & 92 & 110 & 1 & 61 & 199 & 46 \\
\hline $5 / 13$ & 36 & 31 & 295 & 1 & 195 & 167 & 19 \\
\hline $5 / 14$ & 26 & 25 & 150 & 1 & 102 & 99 & 25 \\
\hline $5 / 15$ & 25 & 25 & 250 & 1 & 150 & 150 & 19 \\
\hline $5 / 16$ & 29 & 69 & 320 & 1 & 119 & 299 & 23 \\
\hline $5 / 17$ & 12 & 58 & 650 & 1 & 315 & 135 & 13 \\
\hline $5 / 18$ & 11 & 85 & 1525 & 1 & 765 & 916 & 9 \\
\hline $5 / 19$ & 49 & 75 & 5065 & 1 & 2050 & 3139 & 2 \\
\hline $5 / 20$ & 40 & 169 & 1920 & 1 & 1556 & 6573 & 3 \\
\hline $5 / 21$ & 50 & 14 & 5080 & 1 & 2098 & 3106 & 2 \\
\hline $5 / 22$ & 32 & 65 & 3950 & 1 & 1335 & 2712 & 2 \\
\hline $5 / 23$ & 47 & 49 & 3800 & 1 & 1907 & 1989 & 2 \\
\hline $5 / 24$ & 60 & 60 & 1635 & 1 & 878 & 878 & 1 \\
\hline $5 / 25$ & 49 & 51 & 810 & 1 & 446 & 464 & 11 \\
\hline $5 / 26$ & 85 & 29 & 675 & 1 & 599 & 190 & 11 \\
\hline $5 / 27$ & 99 & 42 & 500 & 1 & 446 & 193 & 22 \\
\hline $5 / 28$ & 11 & 51 & 165 & 1 & 165 & 125 & 13 \\
\hline $5 / 29$ & 12 & 57 & 1560 & 1 & 2617 & 2072 & 3 \\
\hline $5 / 30$ & 12 & 38 & 610 & 1 & 471 & 249 & 15 \\
\hline $5 / 31$ & 39 & 90 & 600 & 1 & 220 & 509 & 18 \\
\hline $6 / 1$ & 22 & 32 & 380 & 1 & 171 & 257 & 12 \\
\hline $6 / 2$ & 69 & 66 & 250 & 1 & 197 & 188 & 35 \\
\hline $6 / 3$ & 39 & 63 & 250 & 1 & 190 & 221 & 29 \\
\hline $6 / 4$ & 39 & 63 & 50 & 1 & 56 & 95 & 67 \\
\hline $6 / 5$ & 39 & 61 & 150 & 1 & 98 & 153 & 10 \\
\hline $6 / 6$ & 33 & 19 & 90 & 1 & 69 & 103 & 48 \\
\hline $6 / 1$ & 10 & 60 & 130 & 1 & 92 & 138 & 13 \\
\hline
\end{tabular}


Appendix H. continued

$\begin{array}{rrrrrrrr}6 / 8 & 81 & 65 & 220 & 1 & 208 & 161 & 10 \\ 6 / 9 & 62 & 38 & 180 & 1 & 114 & 106 & 36 \\ 6 / 110 & 11 & 21 & 0 & 1 & 11 & 29 & 100 \\ 6 / 11 & 63 & 31 & 10 & 1 & 107 & 63 & 59 \\ 6 / 13 & 21 & 21 & 0 & 2 & 12 & 12 & 100 \\ 6 / 15 & 11 & 31 & 0 & 2 & 6 & 16 & 100 \\ 6 / 19 & 13 & 51 & 0 & 2 & 1 & 26 & 100 \\ 6 / 18 & 13 & 9 & 0 & 1 & 13 & 9 & 100 \\ 6 / 20 & 2 & 3 & 0 & 2 & 1 & 2 & 100\end{array}$

1/ Source: Cruir fisheries office.

2) The aunber of days that the trap yas run that produced the actual saple 3/ Percentage sapled of total fish for the tine period. 
Appendix I. Coded-wire tagging of juvenile salronids in 1988 for release into the Umatilla River Basin to evaluate acclimation.

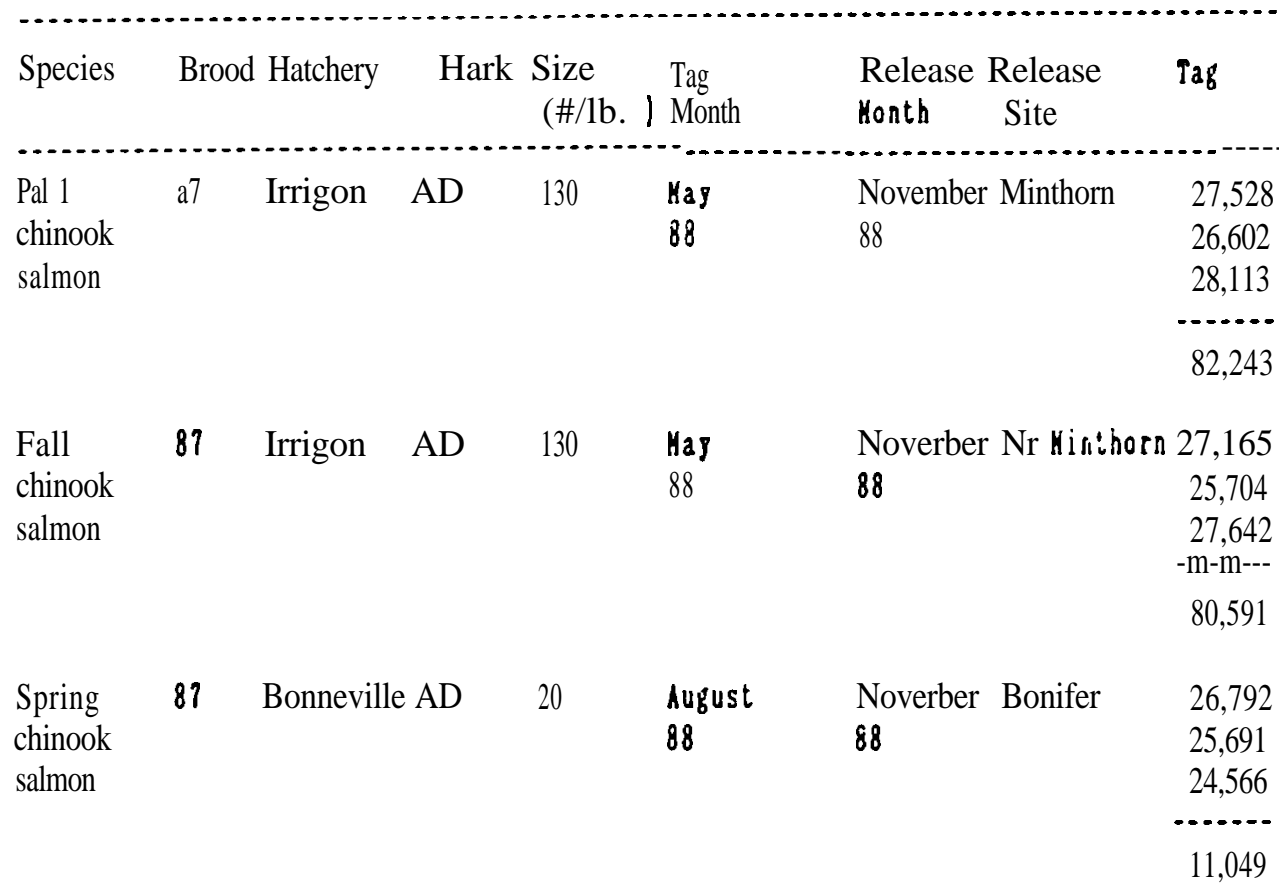

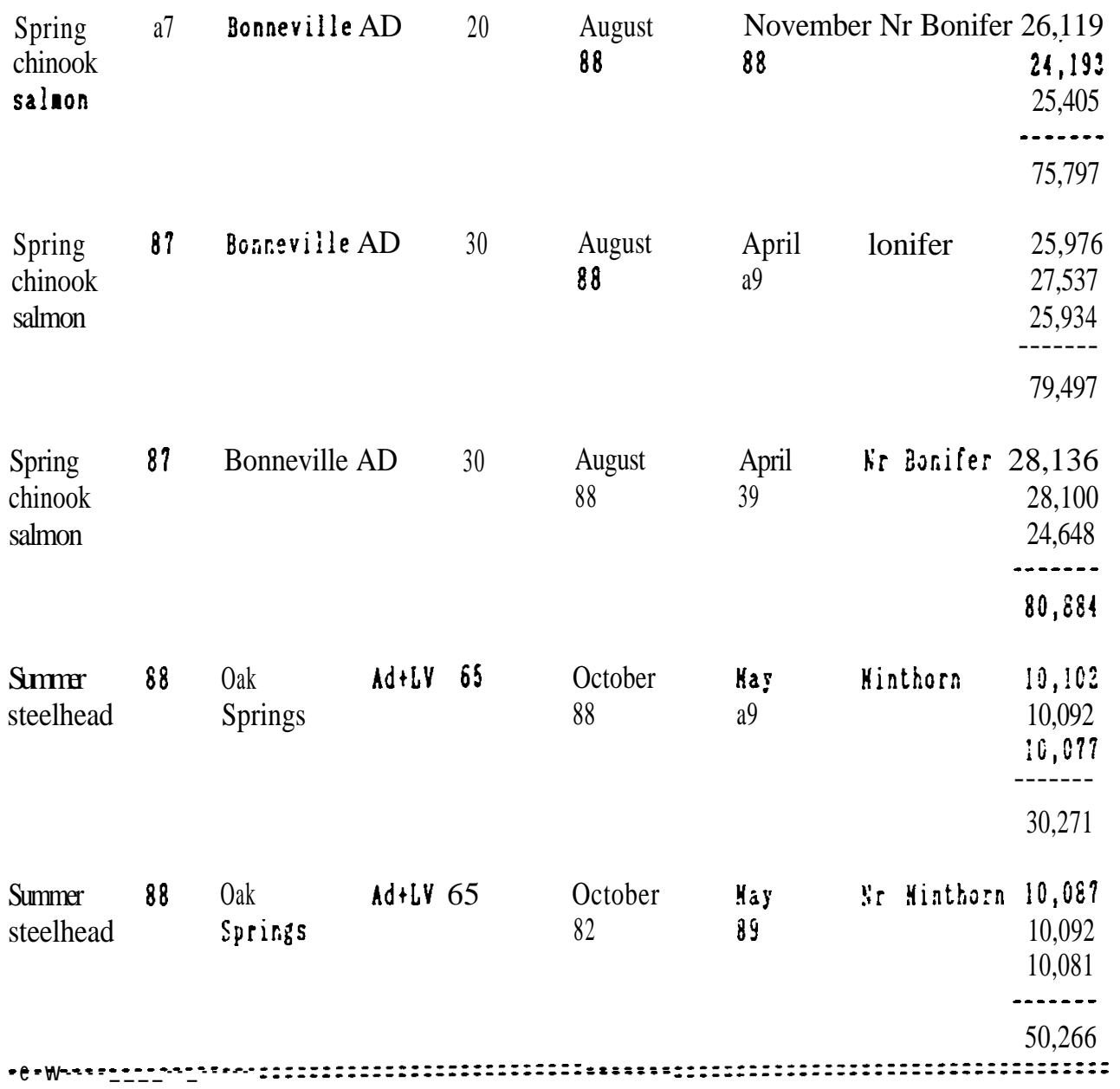

$\mathrm{AD}=$ adipose fin clip

$\mathrm{LV}=$ left pelvic fin clip 